\title{
Iron Phosphate Glass-Containing Hanford Waste Simulant
}

\author{
GJ Sevigny \\ ML Kimura \\ CM Fischer \\ MJ Schweiger \\ DS Kim
}

August 2011

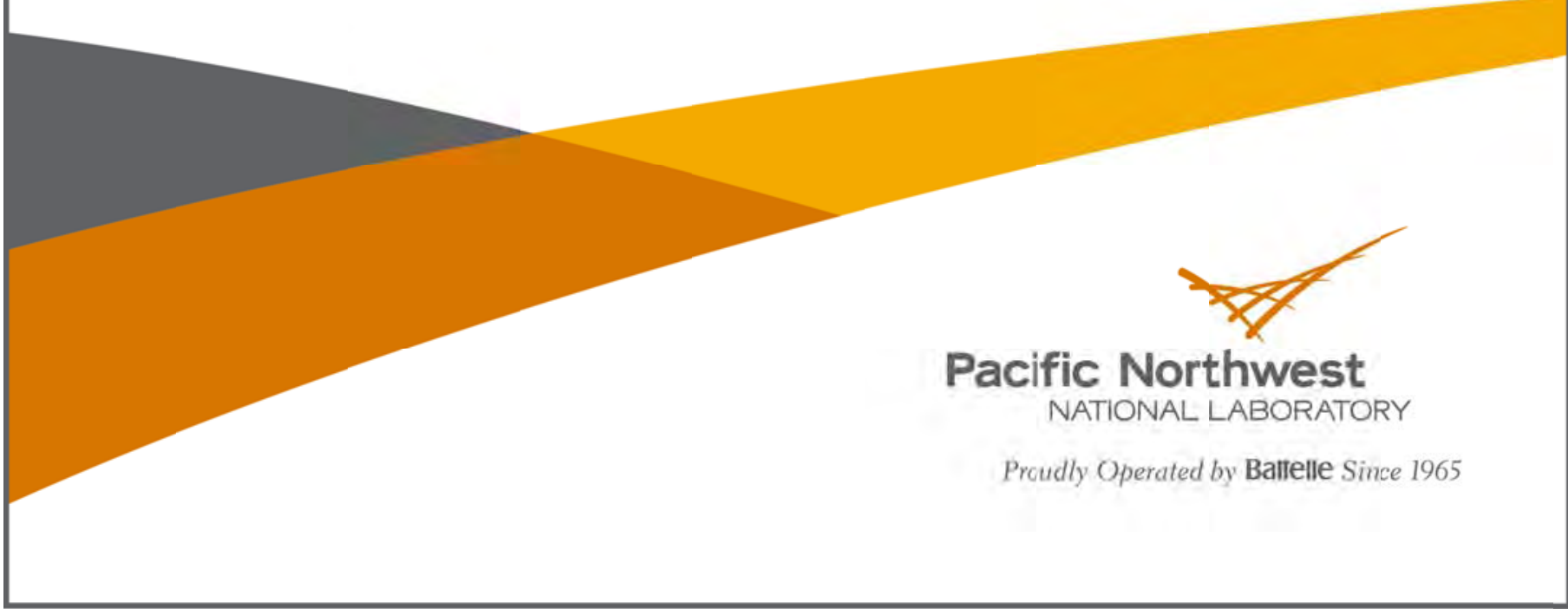




\title{
DISCLAIMER
}

This report was prepared as an account of work sponsored by an agency of the United States Government. Neither the United States Government nor any agency thereof, nor Battelle Memorial Institute, nor any of their employees, makes any warranty, express or implied, or assumes any legal liability or responsibility for the accuracy, completeness, or usefulness of any information, apparatus, product, or process disclosed, or represents that its use would not infringe privately owned rights. Reference herein to any specific commercial product, process, or service by trade name, trademark, manufacturer, or otherwise does not necessarily constitute or imply its endorsement, recommendation, or favoring by the United States Government or any agency thereof, or Battelle Memorial Institute. The views and opinions of authors expressed herein do not necessarily state or reflect those of the United States Government or any agency thereof.

\author{
PACIFIC NORTHWEST NATIONAL LABORATORY \\ operated by \\ BATTELLE \\ for the \\ UNITED STATES DEPARTMENT OF ENERGY \\ under Contract DE-AC05-76RL01830
}

Printed in the United States of America
Available to DOE and DOE contractors from the Office of Scientific and Technical Information,
P.O. Box 62, Oak Ridge, TN 37831-0062;
ph: $(865)$ 576-8401
fax: $(865) 576-5728$
email: reports@adonis.osti.gov
Available to the public from the National Technical Information Service
5301 Shawnee Rd., Alexandria, VA 22312 ph: (800) 553-NTIS (6847)
email: orders@ntis.gov <http://www.ntis.gov/about/form.aspx>
Online ordering: http://www.ntis.gov

This document was printed on recycled paper. 
PNNL-20670

EMSP-RPT-005

\title{
Iron Phosphate Glass-Containing Hanford Waste Simulant
}

\author{
GJ Sevigny \\ ML Kimura \\ CM Fischer \\ MJ Schweiger \\ DS Kim
}

August 2011

Prepared for

the U.S. Department of Energy

under Contract DE-AC05-76RL01830

Pacific Northwest National Laboratory

Richland, Washington 99352 



\section{Summary}

Resolution of the nation's high-level tank waste legacy requires the design, construction, and operation of large and technically complex one-of-a-kind processing waste treatment and vitrification facilities. While the ultimate limits for waste loading and melter efficiency have yet to be defined or realized, significant reductions in glass volumes for disposal and mission life may be possible with advancements in melter technologies and/or glass formulations.

This test report describes the experimental results from a small-scale test using the research-scale melter (RSM) at Pacific Northwest National Laboratory (PNNL) to demonstrate the viability of iron phosphate-based glass with a selected waste composition that is high in sulfates (4.37 wt\% $\left.\mathrm{SO}_{3}\right)$. The primary objective of the test was to develop data to support a cost-benefit analysis as related to the implementation of phosphate-based glasses for Hanford low activity waste (LAW) and/or other high-level waste streams within the U.S. Department of Energy complex. The testing was performed by PNNL and supported by Idaho National Laboratory, Savannah River National Laboratory, and Mo-Sci Corporation.

The RSM is a small, joule-heated melter capable of processing melter feed on a continuous basis. The melter is equipped with Inconel ${ }^{\mathrm{TM}} 693$ electrodes, Monofrax K-3 ${ }^{\mathrm{TM}}$ refractory, and an Inconel ${ }^{\mathrm{TM}} 690$ pour spout. An electric kiln surrounded the melter body and minimized heat loss from the melter body during operation. The RSM was equipped with an offgas treatment system that included quenching, wet scrubbing, and high efficiency mist elimination. The glass discharge section was heated to facilitate pouring of the glass. The melter cavity was $15 \mathrm{~cm}$ in diameter with a nominal glass depth of $7.6 \mathrm{~cm}$. The melter was operated with a glass target temperature of $1030^{\circ} \mathrm{C}$ and a plenum temperature between 300 and $600^{\circ} \mathrm{C}$.

The RSM test was broken into five segments to determine the effects of adding sugar to the feed and subsurface air injection through the molten glass, both of which are included in the current WTP plant design. The test segments were:

1. No sugar, no air bubbler

2. No sugar, air bubbler short duration

3. Sugar, no air bubbler

4. Sugar, air bubbler

5. No sugar, air bubbler long duration.

The average glass production rate was 0.31 to $1 \mathrm{~kg} / \mathrm{h}$ (411 to $\left.1330 \mathrm{~kg} / \mathrm{m}^{2} / \mathrm{day}\right)$. The addition of sugar and air bubbling increased the processing rate as expected. The glass production rate was more than double when both sugar and air bubbling were used. Overall, the test produced $124 \mathrm{~kg}$ of glass. The glass produced met all the durability requirements for LAW. The average glass density was $2.77 \mathrm{~g} / \mathrm{cc}$. The Product Consistency Test results showed release rates less than $3 \mathrm{~g} / \mathrm{L}$ for $\mathrm{Na}$ and below detection for $\mathrm{Cr}$ and B. The quenched Vapor Phase Hydration Test (VHT) samples had very little corrosion present following the 7-day test at $200^{\circ} \mathrm{C}$. The canister centerline cooling heat-treated samples had measured corrosion from 200 to just under $1100 \mathrm{~g} / \mathrm{m}^{2}$ for the VHT.

At the conclusion of the test, the melter and exhaust lines were inspected. The melter electrodes and bubbler tube were removed from the glass in the RSM. The electrodes looked discolored but a significant amount of metal did not appear to be removed. The edges of the electrodes were sharp with small 
differences between before and after measurements. The electrodes were also examined with an optical microscope and a scanning electron microscope (SEM). One thin section was cut from the side of the electrode and examined. A corrosion rate based on the measured values from the SEM scan suggests losses of $<2.5 \mathrm{~mm} /$ year.

Samples of glass and offgas condensate were collected during the test for mass balance information and glass durability measurements.

The data shows average losses from the melter of $30 \mathrm{wt} \%$ for $\mathrm{S}$ but within the requirements for the low-level waste melter. The Re (substitute for Tc) losses were $20 \%$ based on the feed to offgas values and $70 \%$ based on the feed to glass values. The material balance for Re was not closed and may be due to inefficiencies of the offgas scrubbing equipment and solutions. The offgas condensate data, along with the feed rate and concentration data, also indicates that air bubbling likely increased overall losses from the melter, but especially enhanced losses of $\mathrm{S}$ from the melter.

Overall, the processing of iron phosphate-based glass was similar to borosilicate glass, although the melter was operated at a lower average temperature $\left(1030^{\circ} \mathrm{C}\right)$ with higher levels of $\mathrm{S}$. The glass production rates were similar to borosilicate glass when sugar and/or bubbling were used. The product glass quality met all low-level waste criteria with and without sugar additions, although there were significant crystals in the canister centerline cooling samples. The corrosion of melter components was acceptable and losses to the melter exhaust were typical of other waste glasses. 


\section{Acknowledgments}

The authors of this report would like to acknowledge all the help in completing the test and sample analyzes for this report: Nick Soelberg of INL for specification and procurement of the simulated waste and glass formers for the tests; Mo-Sci Corporation for the glass development work, corrosion testing and early glass performance tests, especially for Delbert Day's passionate interest and help in all phases of the glass development and melter operation; Fabienne Johnson of SRNL for the PCT glass performance tests and sample analyses; and Jim Davis and Harold Adkins of PNNL for the all the effort in preparing the RSM equipment for operation. 



\section{Acronyms and Abbreviations}

$\begin{array}{ll}\text { ARM } & \text { approved reference material } \\ \text { CCC } & \text { canister centerline cooling } \\ \text { DAC } & \text { data acquisition and control } \\ \text { EPA } & \text { U.S. Environmental Protection Agency } \\ \text { EVS } & \text { ejector venturi scrubber } \\ \text { HEME } & \text { high efficiency mist eliminator } \\ \text { HLW } & \text { high-level waste } \\ \text { ICP-AES } & \text { inductively coupled plasma-atomic emission spectroscopy } \\ \text { ICP-MS } & \text { inductively coupled plasma-mass spectrometry } \\ \text { LAW } & \text { low activity waste } \\ \text { PCT } & \text { Product Consistency Test } \\ \text { PNNL } & \text { Pacific Northwest National Laboratory } \\ \text { RSM } & \text { research-scale melter } \\ \text { SEM } & \text { scanning electron microscope } \\ \text { SRNL } & \text { Savannah River National Laboratory } \\ \text { TCLP } & \text { toxicity characteristic leaching procedure } \\ \text { UDS } & \text { undissolved solids } \\ \text { VHT } & \text { Vapor Phase Hydration Test } \\ \text { WG } & \text { water gage } \\ \text { WTP } & \text { Hanford Tank Waste Treatment and Immobilization Plant } \\ \text { XRD } & \text { X-ray diffraction }\end{array}$





\section{Contents}

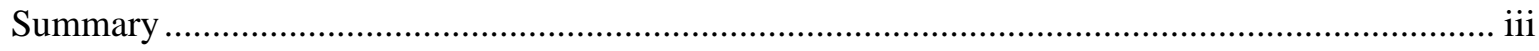

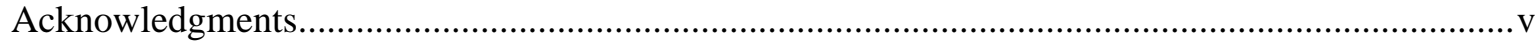

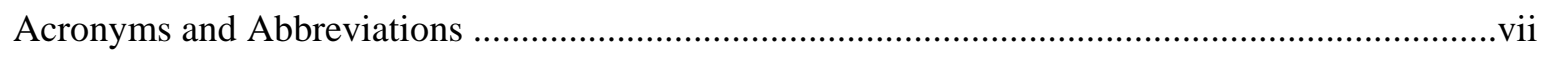

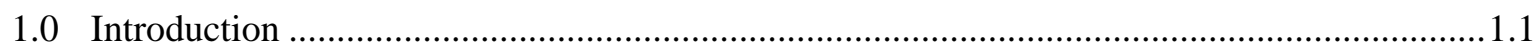

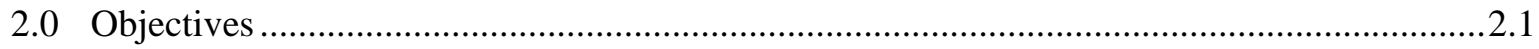

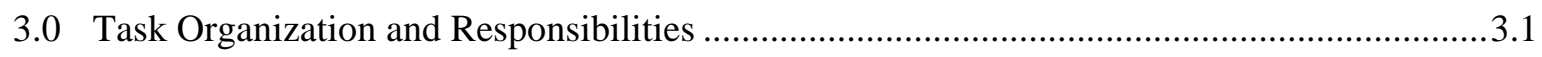

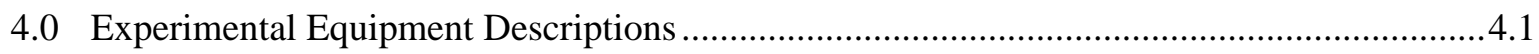

4.1 RSM System Description ......................................................................................... 4.1

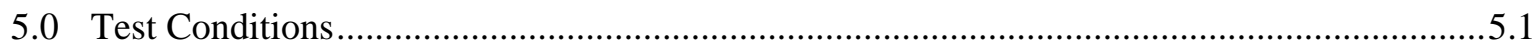

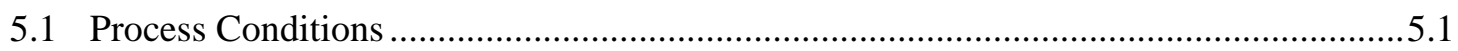

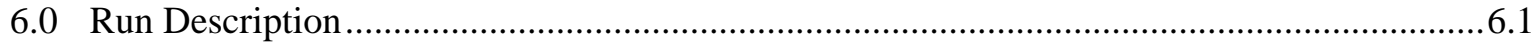

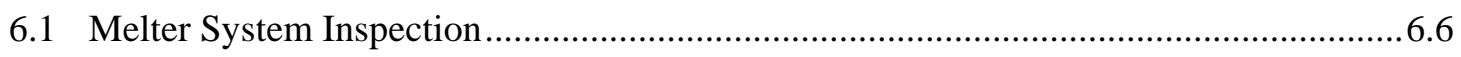

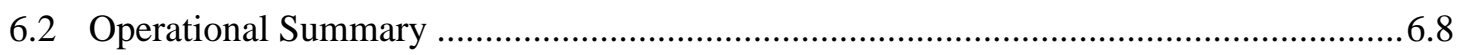

7.0 Data Collection and Sample Collection/Analysis............................................................ 7.1

7.1 Data Collection and Process Controls ....................................................................... 7.1

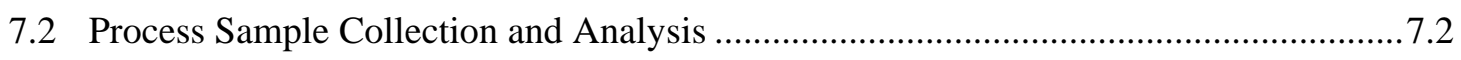

7.3 Sample Analysis Procedures and Equipment ....................................................................

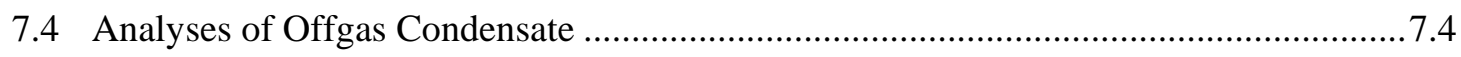

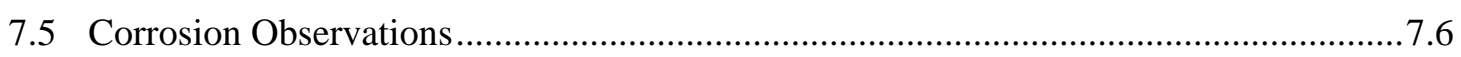

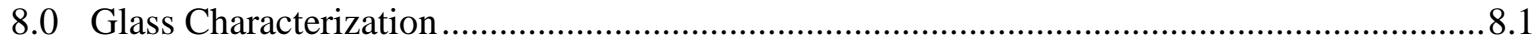

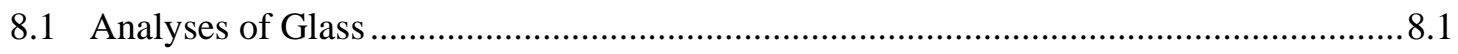

8.2 Toxicity Characteristic Leaching Procedure .............................................................. 8.3

8.3 Heat Treatment of Glass Using Canister Centerline Cooling Profile................................8.3

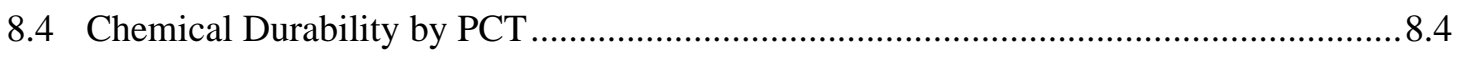

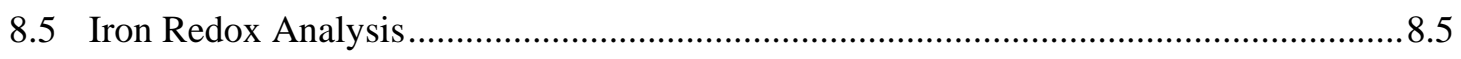

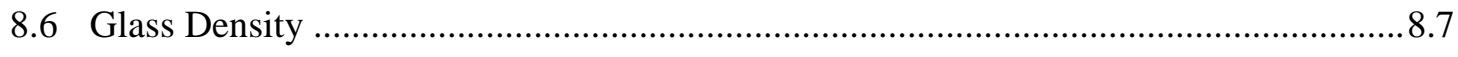

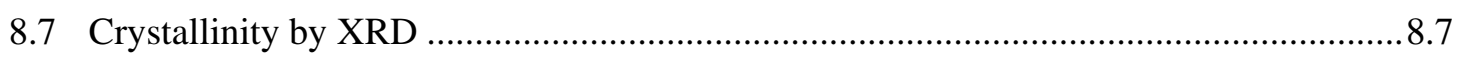

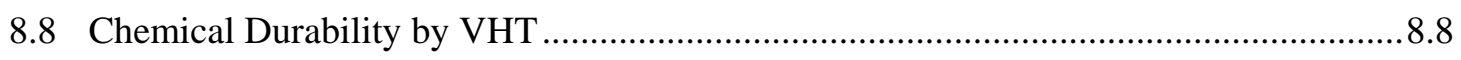

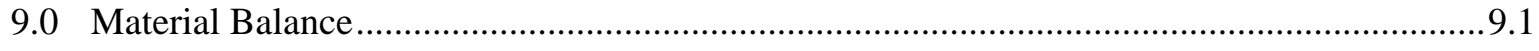

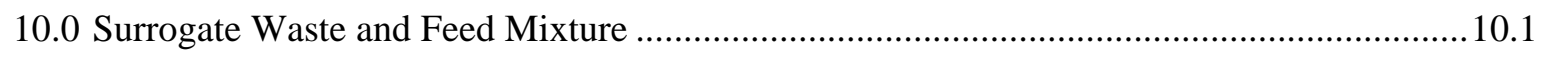

11.0 Quality Assurance....................................................................................................11.1

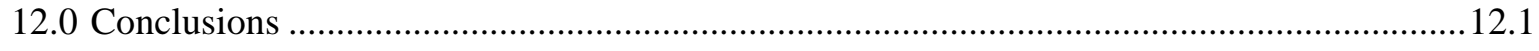

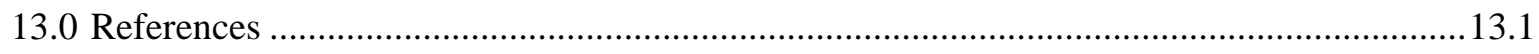

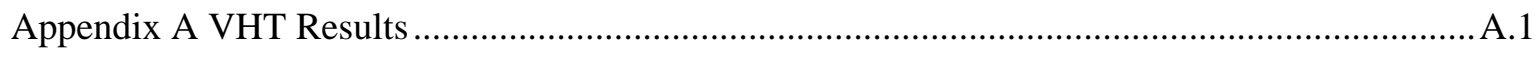

Appendix B XRD Analysis................................................................................................... B.1

Appendix C Research-Scale Melter Measurement and Testing Equipment ................................. C.1 


\section{Figures}

4.1 Research-Scale Melter Test

6.1 Melter Glass, Plenum and Offgas Temperatures .....................................................................

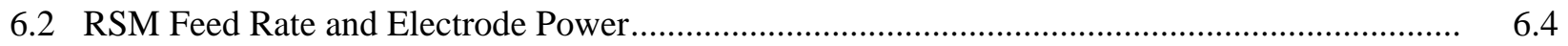

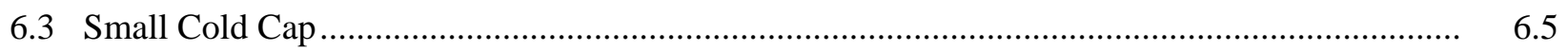

6.4 Segment 3 Molten Glass Surface......................................................................................... 6.5

6.5 Large, Highly Mobile Cold Cap in Segment 3 ................................................................... 6.5

6.6 Melter Electrodes Pulled From the Glass Melt .................................................................. 6.7

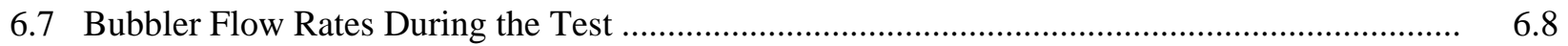

7.1 Optical Micrograph of an Electrode Thin Section ................................................................

7.2 SEM High, 75X Dot Map of Electrode ...........................................................................

7.3 EDS Results From Low and High Regions of the Electrode Showing the Mass \% of Each

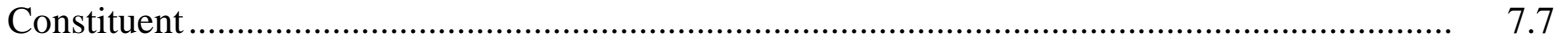

8.1 Graph of CCC Heat Treatments of Both FEP and LAW Glass .............................................

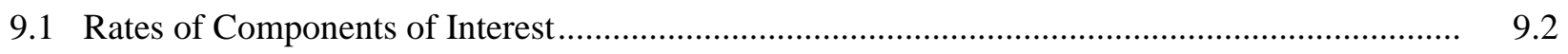

\section{Tables}

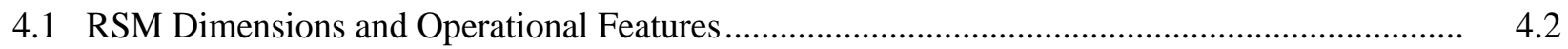

5.1 Target RSM Operating Conditions ................................................................................... 5.1

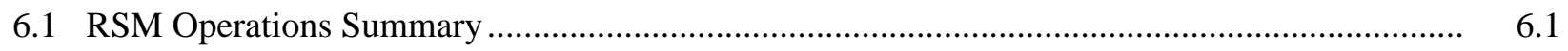

6.2 Plenum and Exhaust Line Deposit Composition ................................................................... 6.7

7.1 RSM Process Data Electronically or Manually Logged ............................................................. 7.1

7.2 Sample Analysis Methods for Process and Offgas Samples....................................................

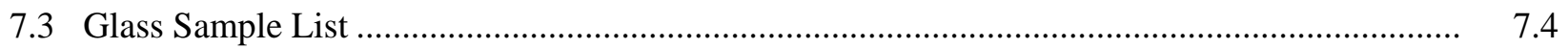

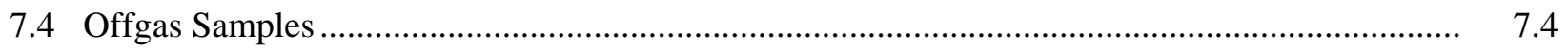

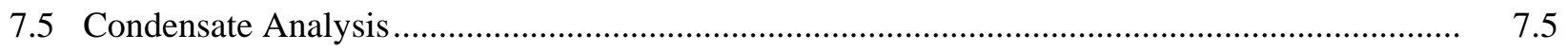

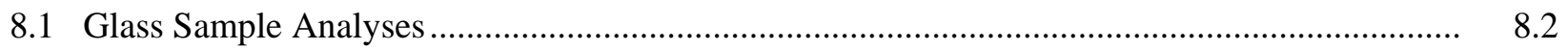

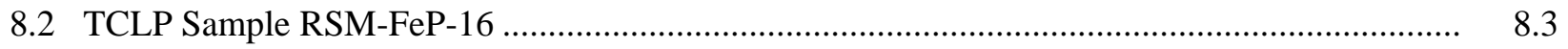

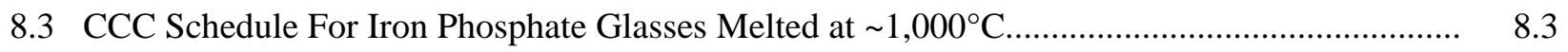

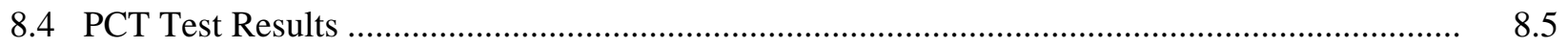

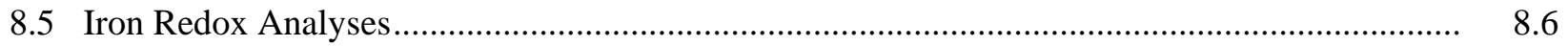

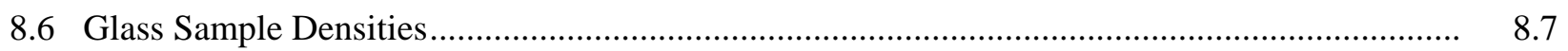

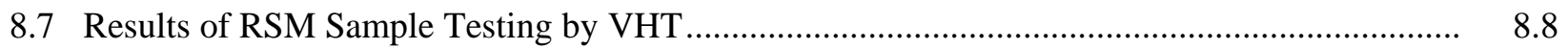

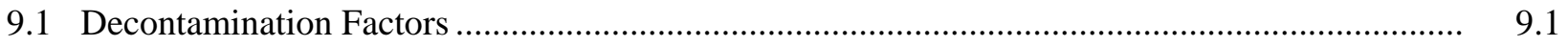

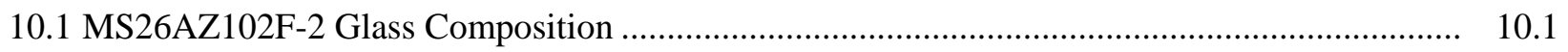




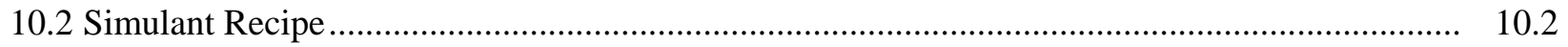

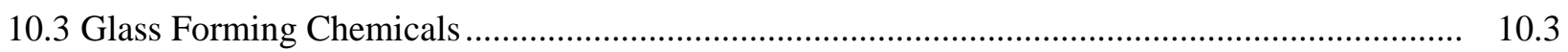





\subsection{Introduction}

Resolution of the nation's high-level tank waste legacy requires the design, construction, and operation of large and technically complex one-of-a-kind processing waste treatment and vitrification facilities. Vitrification technology was chosen to treat the high-level waste (HLW) fraction of tank waste at Hanford and the Savannah River Site, the low activity waste (LAW) fraction of tank waste at Hanford, and potentially other defense waste streams such as Idaho National Laboratory sodium bearing tank waste or calcine HLW. Joule-Heated Ceramic Melters are being used at the Defense Waste Processing Facility and will be used at the Hanford Tank Waste Treatment and Immobilization Plant (WTP) to vitrify tank waste fractions. While the ultimate limits for waste loading and melter efficiency have yet to be defined or realized, significant reductions in glass volumes for disposal and mission life may be possible with advancements in melter technologies and/or glass formulations.

Advanced glass formulations are needed to take advantage of the next generation melter technologies (i.e., Advanced Joule Heated Melters or Cold Crucible Induction Melters). New glass formulations for increased waste loading and melt rates would substantially reduce the volume of glass produced, stored, transported, and disposed; significantly reducing the cost and schedule of tank waste management in the United States.

With respect to advanced glass formulations, phosphate-based glasses may have the potential to offer significant increases in loading of wastes that are high in some components and difficult to dissolve in silicate melts (e.g., S, Cr, P, F, and Cl). However, phosphate glasses are an immature technology relative to alkali-boro-silicate glasses for the vitrification of HLW and LAW. In general, early research on phosphate-based glasses has shown unacceptable corrosion of melter components and crystallization on slow cooling to form low durability waste forms. However, recent studies have shown promise in the ability to formulate iron phosphate-based waste glasses that may not demonstrate the drawbacks found in earlier phosphate formulation studies.

This test report describes the experimental results from a small-scale test using the research-scale melter (RSM) at Pacific Northwest National Laboratory (PNNL) to demonstrate the viability of iron phosphate-based glass with a selected waste composition that is high in sulfates. The test results also show the volatility of S and Tc using Re as a surrogate and the corrosion of melter materials. 



\subsection{Objectives}

The primary objective of the test was to develop data to support a cost-benefit analysis as related to the implementation of phosphate-based glasses for Hanford LAW and/or other HLW streams within the U.S. Department of Energy complex. Data required for such an assessment included, but was not limited to successful production of a durable glass with a high waste loading and retention of sulfates and Tc without causing excessive corrosion in a joule-heated melter. This test demonstrated the flowsheet through a small-scale integrated process test by:

- Obtaining steady feeding operations for a prolonged period using the RSM to determine processing rate and evaluate corrosion of melter electrode and ceramic materials.

- Collecting samples from feed, glass, and offgas components and complete a mass balance to determine fate of Re, S, P and other opportunistic elements. 



\subsection{Task Organization and Responsibilities}

PNNL staff performed the RSM test and collected chemical analyses and glass durability tests of the RSM samples. The Savannah River National Laboratory (SRNL) and Mo-Sci Corporation staff also analyzed some samples. Project responsibilities of each contributing group are described below.

- PNNL provided:

- overall responsibility for the performance of the test

- $\quad$ test facility (RSM system) and support infrastructure (e.g., utilities, electrician, machine shop)

- $\quad$ feed staging

- test instruction preparations

- operational direction during the test series

- $\quad$ RSM process monitors and data logging equipment

- data reduction and test report preparation

- Vapor Phase Hydration (VHT) testing of glass.

- Savannah River Site provided feed, glass, and waste-stream sample analyses.

- Mo-Sci Corporation provided the start-up glass and the glass composition for the test. They also provided some $\mathrm{Fe}^{+2} /$ total iron ratios for the glass.

- Idaho National Laboratory provided the simulated slurry feed and glass formers. 



\subsection{Experimental Equipment Descriptions}

The experimental equipment used to support objectives of this task was the RSM processing system described in this section.

\subsection{RSM System Description}

The PDL-East Building in Richland, Washington housed the RSM system. Figure 4.1 shows the process flow diagram for the RSM test.

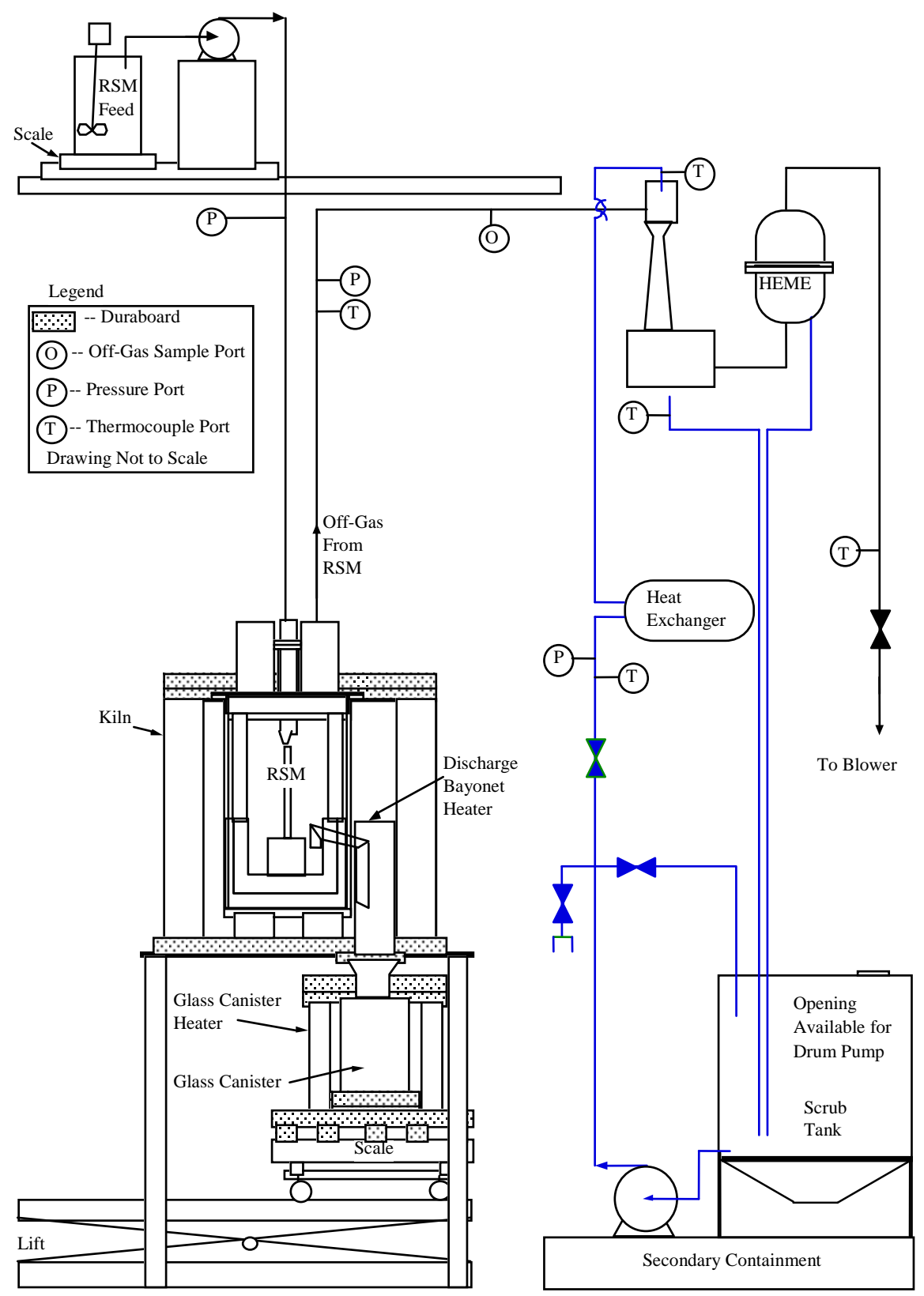

Figure 4.1. Research-Scale Melter Test 
The RSM is a small, joule-heated melter capable of processing melter feed on a continuous basis. This capability is representative of a full-scale system and was key for determining the relationships between the properties of the feed and the properties of the final glass produced. Testing in the RSM allowed for quantitative measurement of the offgas stream and the performance of parametric studies (e.g., changing one feed component at a time to determine its effect on the process) in a relatively short timeframe. The RSM processing system provided unit offgas treatment operations of quenching, wet scrubbing, and high efficiency mist elimination and therefore allowed direct assessment of effluent partitioning behavior. The aqueous quench-scrubber was an ejector venturi scrubber (EVS), previously shown to be functionally equivalent to the WTP submerged-bed scrubber technology (Goles 1992). The exhaust of the RSM EVS was treated by a high efficiency mist eliminator (HEME) that not only demisted the influent stream but efficiently removed sub-micron aerosol matter penetrating the EVS. Table 4.1 provides RSM dimensions and other operational features.

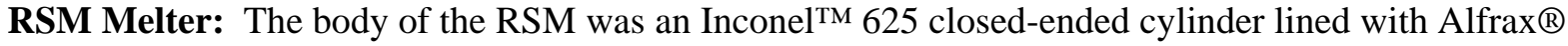
refractory that contained a Monofrax ${ }^{\circledR}$ K3 refractory melt cavity. An Inconel ${ }^{\mathrm{TM}}$ pour spout tube discharged molten glass into a stainless steel canister. An electric kiln surrounded the melter body and minimized heat loss from the melter body during operation. The discharge section was heated to facilitate pouring of the glass. The stainless steel canister sat inside a smaller kiln maintained between 700 and $900^{\circ} \mathrm{C}$ to promote uniform canister filling. Two top-entering Inconel ${ }^{\mathrm{TM}} 693$ electrodes submerged in the glass supplied joule-heating power to the RSM.

RSM Feed System: Melter feed was delivered from a feed tank to the RSM feed nozzle by a peristaltic pump. An agitator in the feed tank kept the slurry well mixed. The feed tank sat on a scale that was monitored by the computer data acquisition and control system. Pump speed (and thus the rate at which feed was introduced into the melter) was controlled from the computer.

EVS: The EVS sprayed solution through a nozzle for direct contact with the melter exhaust. The EVS condensed water from the melter exhaust and removed particulates and some acid gases. The resulting two-phase stream traveled through a separator chamber and the scrubber solution was drained back to the scrub tank. The scrubber solution recirculated from a tank with a pump located adjacent to the RSM platform and through a heat exchanger to remove the heat transferred from the melter exhaust. From the scrubber, the exhaust passed through a HEME to remove condensed-phase aerosols. Collection of the quench scrubber samples was performed periodically during the test.

Table 4.1. RSM Dimensions and Operational Features

\begin{tabular}{ll}
\hline Parameter & Value \\
\hline Melter cavity diameter & $15 \mathrm{~cm}$ \\
Melter cavity height & $17 \mathrm{~cm}$ \\
Melter inside volume & $4.5 \mathrm{~L}$ \\
Nominal glass depth & $7.6 \mathrm{~cm}$ \\
Maximum operating temperature & $1200^{\circ} \mathrm{C}$ \\
Nominal operating Temperature for borosilicate glass & $1150^{\circ} \mathrm{C}$ \\
Electrode Dimensions & $7.6 \times 7.6 \mathrm{~cm}$ \\
Electrode Material & Inconel ${ }^{\mathrm{TM}} 693$ \\
Electrode distance from bottom & $0 \mathrm{~cm}$ \\
Electrode current (average) & $120 \mathrm{~A}$ \\
Electrode voltage (average) & $10-35 \mathrm{~V}$ \\
Electrode current density (average/maximum) & $1.6 / 3.5 \mathrm{~A} / \mathrm{cm}^{2}$ \\
\hline
\end{tabular}




\subsection{Test Conditions}

To satisfy the technical objectives of this flowsheet, approximately 10 days of continuous, $24 \mathrm{hr} /$ day melter operation was targeted. The process condition targets used during testing are described below and in Table 5.1.

Table 5.1. Target RSM Operating Conditions

\begin{tabular}{lr}
\hline \multicolumn{1}{c}{ Parameter } & \multicolumn{1}{c}{ Target } \\
\hline Melt surface area & $182 \mathrm{~cm}^{2}$ \\
Melt volume & $1.4 \mathrm{~L}$ \\
Glass specific gravity & 3.2 \\
Glass inventory & $4.2 \mathrm{~kg}$ \\
Minimum expected glass rate & $0.30 \mathrm{~kg} / \mathrm{h}$ \\
Maximum expected glass rate & $0.61 \mathrm{~kg} / \mathrm{h}$ \\
Minimum expected feed rate & 0.55 liters $/ \mathrm{hr}$ \\
Maximum expected feed rate & 1.11 liters/hr \\
Glass melt temperature & $1030^{\circ} \mathrm{C}$ \\
Plenum temperature range & 300 to $600^{\circ} \mathrm{C}$ \\
Plenum pressure & 200 to $350^{\circ} \mathrm{C}$ \\
Post-film-cooler temperature range & $1-3 \mathrm{scfm}$ \\
Air inleakage rate & $80 \mathrm{~L}$ \\
Initial scrub solution volume & 6 to $8 \mathrm{pH}$ \\
Initial scrub solution & -1.5 inches water \\
\hline
\end{tabular}

\subsection{Process Conditions}

The major process conditions that were controlled were glass pool temperature, melter vacuum, feed composition, plenum temperature, cold cap coverage, and melter feed rate. Strategies for maintaining baseline conditions are discussed below.

Glass Pool Temperature: The $1030^{\circ} \mathrm{C}$ target was automatically controlled by the RSM control system. The limiting electrode current density of $\leq 3.5 \mathrm{~A} / \mathrm{cm}^{2}(\sim 200 \mathrm{~A})$ was a constraint considered in maintaining the glass temperature. Kiln temperature setpoints could be adjusted to mitigate potential glass temperature control problems. However, both parameters directly influenced plenum and offgas temperature and had to be subsequently adjusted to meet baseline expectations.

Melter Vacuum: Melter pressure was automatically controlled at a setpoint, nominally between 0.5 and 2 in. of water gage (WG) below ambient conditions. The RSM blower provided up to 28 in. WG vacuum (at $200 \mathrm{cfm}$ ), most of which was dropped across the control valve under standard operating conditions. 
Melt Pool Bubbling Rate: Glass pool agitation using subsurface air injection was employed to enhance melter feed processing rates. To accomplish this, a flow meter delivered air at 1 to1.5 liters/min through one submerged Inconel ${ }^{\mathrm{TM}} 625$ tube. Optimizing processing rate was not a primary test objective; bubbling rate was a secondary parameter that did not compromise the attainment of primary operational targets (temperatures).

Feed Composition: One feed composition was used throughout the test with the addition of sugar as a reductant for two test segments.

Processing Rate: Maximum steady state processing rates for the current base melter feed were established by cold-cap conditions. The target coverage was 85 to 95\%. To achieve specific processing rates within the expectation range of 0.4 to $0.8 \mathrm{MT} / \mathrm{d} / \mathrm{m}^{2}$, feeding rates between 0.55 and $1.1 \mathrm{l} / \mathrm{hr}$ were necessary. Glass foaming was the greatest threat to achieving processing rates within the target range. Bubbling and reductant additions were test parameters introduced to counteract the limiting influence of foaming conditions. When bubbling was used to mitigate feed rate difficulties, concomitant changes in plenum offgas conditions were compensated for. When reductant was used to remedy foaming, the minimum necessary concentration of sugar was used.

Plenum Temperature: The targeted plenum temperature range was $500 \pm 100^{\circ} \mathrm{C}$ during maximum feeding activities. Under steady state processing conditions (90 to 95\% cold cap coverage), inleakage, melter kiln temperature, and bubbling rate were all used to influence this steady state temperature.

Offgas Temperature: Post-film-cooler, unquenched offgas temperature was constrained to $<350^{\circ} \mathrm{C}$. Since film-cooler injection rate was primarily established to control temperature, it was the primary adjustment for temperature control.

Quench-Scrubber Condensate Temperature: The expected EVS liquor temperature was $\sim 20$ to $35^{\circ} \mathrm{C}$. If there was a need to increase or decrease this temperature, the cooling flow rate of the condensate heat exchanger was appropriately adjusted.

At a given set of operating conditions, some operating time was needed to allow time for the melt bath composition to approach a new equilibrium after step changes in the feed composition that affected the melt composition (i.e., the addition or removal of sugar). A 6 to $12 \mathrm{hr}$ melt cavity turnover frequency was determined adequate based on the RSM molten glass volume. Since up to three bath volume turnovers were needed to achieve steady state composition of the melter glass inventory, a minimum of 18 processing hours at a $0.8 \mathrm{MT} / \mathrm{d} / \mathrm{m}^{2}$ production rate was needed to reach true steady state processing conditions; however it was expected to take almost $40 \mathrm{hr}$ to reach steady conditions at low production rates. 


\subsection{Run Description}

The RSM test to produce iron phosphate glass was broken into five segments to determine the effects of adding sugar to the feed and subsurface air injection through the molten glass, both of which are included in the current WTP plant design. Sugar was added as a reductant to the RSM feed reservoir during test segments where its effect was under consideration. The air bubbler was fabricated from an Inconel $^{\text {TM }} 625$ alloy tubing. The bubbler tip was submerged in the molten glass pool to aid in convective mixing of the glass for some test segments. The test segments were:

1. No sugar, no air bubbler

2. No sugar, air bubbler

3. Sugar, no air bubbler

4. Sugar, air bubbler

5. No sugar, air bubbler.

The glass in all test segments was melted under similar operating conditions as discussed in Section 3.0 and shown graphically in Appendix D. A summary of the main operating parameters during each segment is given in Table 6.1.

Table 6.1. RSM Operations Summary

\begin{tabular}{|c|c|c|c|c|c|c|c|c|c|}
\hline $\begin{array}{c}\text { Seg } \\
\#\end{array}$ & $\begin{array}{l}\text { Start } \\
\text { Date }\end{array}$ & $\begin{array}{l}\text { Start } \\
\text { Time } \\
\end{array}$ & $\begin{array}{c}\text { Total } \\
\text { Hours } \\
\end{array}$ & $\begin{array}{c}\text { Sugar } \\
(\mathrm{g} / \mathrm{l})\end{array}$ & $\begin{array}{c}\text { Avg. } \\
\text { Plenum } \\
\text { Temp } \\
\left({ }^{\circ} \mathrm{C}\right) \\
\end{array}$ & $\begin{array}{c}\text { Avg. } \\
\text { Glass } \\
\text { Temp } \\
\left({ }^{\circ} \mathrm{C}\right) \\
\end{array}$ & $\begin{array}{c}\text { Bubbler } \\
\text { rate } \\
\text { (slpm) }\end{array}$ & $\begin{array}{c}\text { Avg. } \\
\text { Feed } \\
\text { Rate }^{(a)} \\
(\mathrm{L} / \mathrm{h})\end{array}$ & $\begin{array}{c}\text { Avg. } \\
\text { Glass } \\
\text { Rate } \\
(\mathrm{kg} / \mathrm{h}) \\
\end{array}$ \\
\hline 1 & $11 / 30$ & 1053 & 34 & 0 & 594 & 1024 & 0 & 0.54 & 0.41 \\
\hline 2 & $12 / 1$ & 2000 & 14.7 & 0 & 572 & 1028 & 1 & 0.64 & 0.55 \\
\hline 3 & $12 / 2$ & 1043 & 92.4 & 50 & 534 & 1030 & 0 & 0.86 & 0.46 \\
\hline 4 & $12 / 6$ & 0705 & 54.7 & 50 & 571 & 1027 & $1-1.5$ & 1.07 & 0.96 \\
\hline 5 & $12 / 8$ & 1348 & 43.7 & 0 & 549 & 1030 & 1.5 & 0.82 & 0.57 \\
\hline
\end{tabular}

The RSM operating segments were targeted to have at least three melter turnovers of glass and a prolonged period of operation at a consistent feed rate. The operation of the melter was sufficient to satisfy the melter-related objectives and to obtain basic operational data. The maximum steady feed rate was attempted but was not optimized in all segments. Feed line and feed nozzle plugging problems were the primary cause of disruption during processing and the limitation to obtaining a steady equilibrium melt rate. The feed did not seem to settle out in the feed tank, as evidenced by a lack of material in the bottom of the tanks when the tanks were emptied after test completion. Feed line plugging for the RSM was an operating challenge due to the low RSM feed rates. The feed line velocities were very slow and a smaller line size would not be practical with slurries. Therefore, plugging was not expected to be as problematic in a larger scale system.

The test started on November 30, 2010 at 1053 hrs and ended on December 10, 2010 at 0930 hrs, producing $124.4 \mathrm{~kg}$ of glass. Before the actual feed processing started, the melter was loaded with start-up glass (targeting the MS26AZ102-F-2 composition) and heated with the melter kiln heater to bake out the castable refractory behind the Monofrax K-3. The melter was then allowed to cool over the Thanksgiving holiday weekend. The melter kiln heater was restarted on Monday, November 29, 2010 to 
melt the solidified start-up glass in the melter refractory prior to initiating joule heating of the glass. The kiln was operating at $100 \%$ power and the glass temperature was $700^{\circ} \mathrm{C}$ before joule heating was started at 1458 hrs. The melter reached the targeted temperature of $1030^{\circ} \mathrm{C}$ at 1721 hrs. Shakedown testing with feed began at 1854 hrs and continued until 2150 hrs on Monday, and then restarted on Tuesday. Testing operations were initiated at $1053 \mathrm{hrs}$ although refinements to the processing continued during testing. Plots of melter power, melter feed rate, plenum temperature, glass temperature and offgas temperature are shown in Figure 6.1 and Figure 6.2.

Segment 1 (no sugar, bubbler off) commenced on November 30, 2010 at 1053 hrs with an initial feed rate of $1 \mathrm{l} / \mathrm{hr}$ based on rates achieved during shakedown testing; however, excessive glass foaming quickly became an issue which required that the feed rate be decreased significantly. Difficulties were observed with melter power interfering with the melter temperature measurement taken by thermocouples inserted in each electrode pipe. This was not observed during the shakedown testing and was corrected by isolating the thermocouples from each other, reading one temperature on a handheld device while collecting the other using the data acquisition system discussed in Section 7.0. The average glass temperature was $1024^{\circ} \mathrm{C}$.

During Segment 1, a relatively thick layer of foam developed outside the main cold cap and formed a 'cold' area around the perimeter of the molten glass surface (Figure 6.3). This cold area became a cold glass bridge that quickly grew to cover the entire surface. The feed was shut off temporarily to allow the residual heat in the molten glass pool to dissolve the frozen glass bridge. The foaming/freezing cycle continued throughout Segment 1. An average feed rate for Segment 1 was ultimately achieved at $0.54 \mathrm{~L} / \mathrm{hr}$ with a glass production rate of $0.41 \mathrm{~kg} / \mathrm{hr}\left(544 \mathrm{~kg} / \mathrm{m}^{2} /\right.$ day $)$.

For Segment 2 (no sugar, bubbler on) an air bubbler was introduced into the melter on December 1, 2010 at 2000 hrs with a flow rate of approximately 1 l/min. This segment ran for about $15 \mathrm{hr}$ and resulted in a significantly higher feed rate than without bubbling. The average feed rate for Segment 2 was $0.64 \mathrm{~L} / \mathrm{hr}$ and the glass production rate was $0.55 \mathrm{~kg} / \mathrm{h}\left(733 \mathrm{~kg} / \mathrm{m}^{2} /\right.$ day $)$. To confirm the feed rate, this condition was repeated in Segment 5 for a longer duration.

Segment 3 (sugar, bubbler off) started on December 2, 2010 at 1043 hrs and required the addition of $50 \mathrm{~g} / \mathrm{l}$ of sugar to the feed. Melter operation became more stable and a higher feed rate was achieved than in Segment 1 (without sugar). The bubble diameter in the layer of foam at the periphery of the cold cap on the molten glass surface appeared to be larger and bubbles rolled continuously (Figure 6.4). The average feed rate for Segment 3 was $0.86 \mathrm{~L} / \mathrm{hr}$ and the glass production rate was $0.46 \mathrm{~kg} / \mathrm{hr}$ $\left(611 \mathrm{~kg} / \mathrm{m}^{2} /\right.$ day).

The highest feed rates were achieved in Segment 4 (sugar added, bubbler on), which started on December 6, 2010 at 0705. For this segment, the air bubbler was used and $50 \mathrm{~g} / \mathrm{l}$ sugar was added to the feed. Without a mass flow controller, it was difficult to control the bubbler rate using only a $0-10 \mathrm{l} / \mathrm{min}$ rotometer; at times, bubbler rates higher than the designated $1 \mathrm{l} /$ min were observed during data collection (there was also no automatic data collection of the bubbler rate). Vigorous bubbling was observed in the molten glass surrounding the cold cap (Figure 6.5). So much activity existed that a few times the entire cold cap rolled and was engulfed in the molten glass. The feed rate was increased until a large, thick cold cap almost fully covered the molten glass, at which time the rate was decreased and steady state was achieved. The average feed rate for Segment 4 was $1.07 \mathrm{~L} / \mathrm{hr}$ and the glass production rate was $0.96 \mathrm{~kg} / \mathrm{hr}$ $\left(1265 \mathrm{~kg} / \mathrm{m}^{2} /\right.$ day). The higher bubbler flow rates resulted in higher feed rates and glass production rates. 


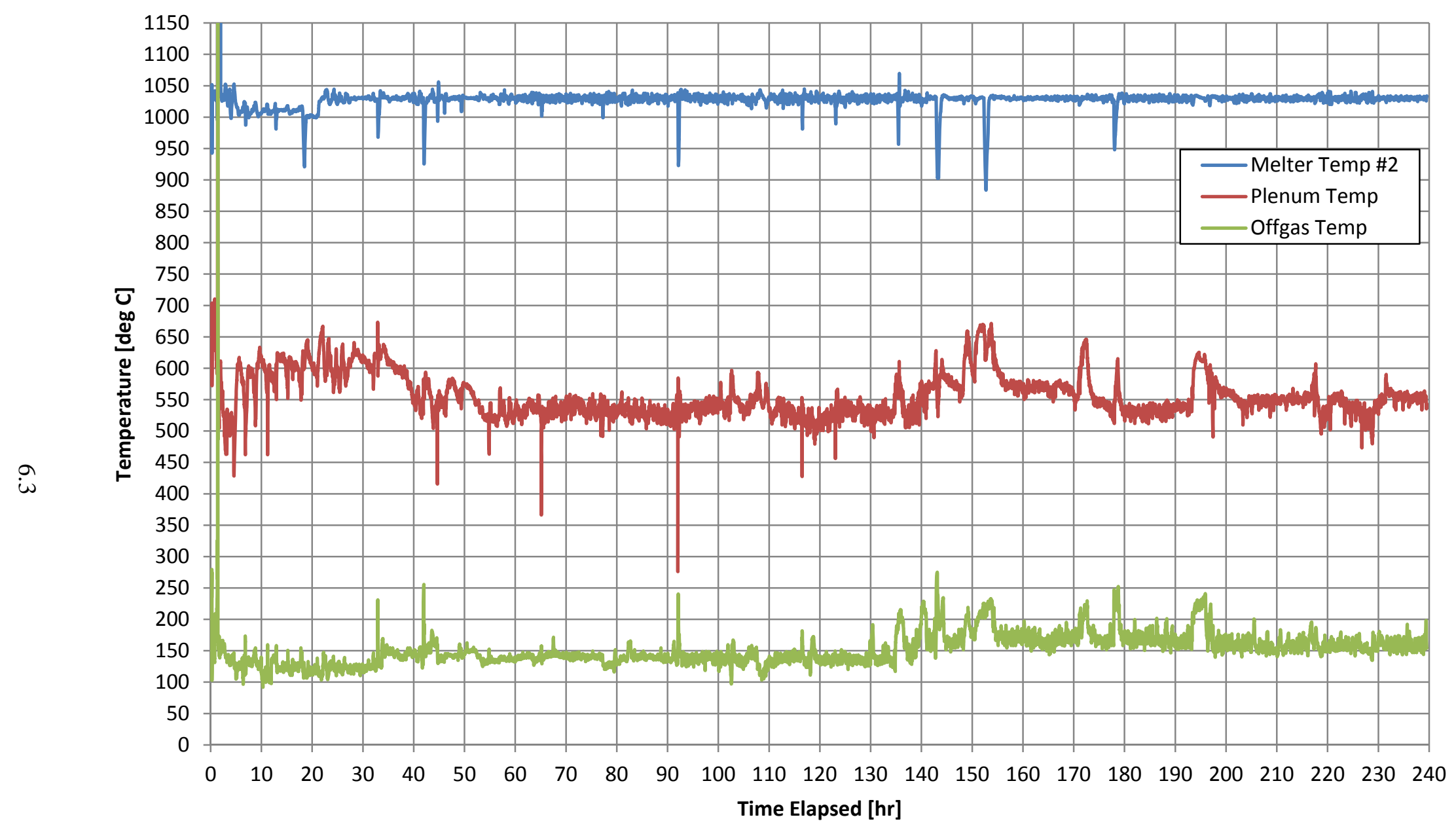

Figure 6.1. Melter Glass, Plenum and Offgas Temperatures 


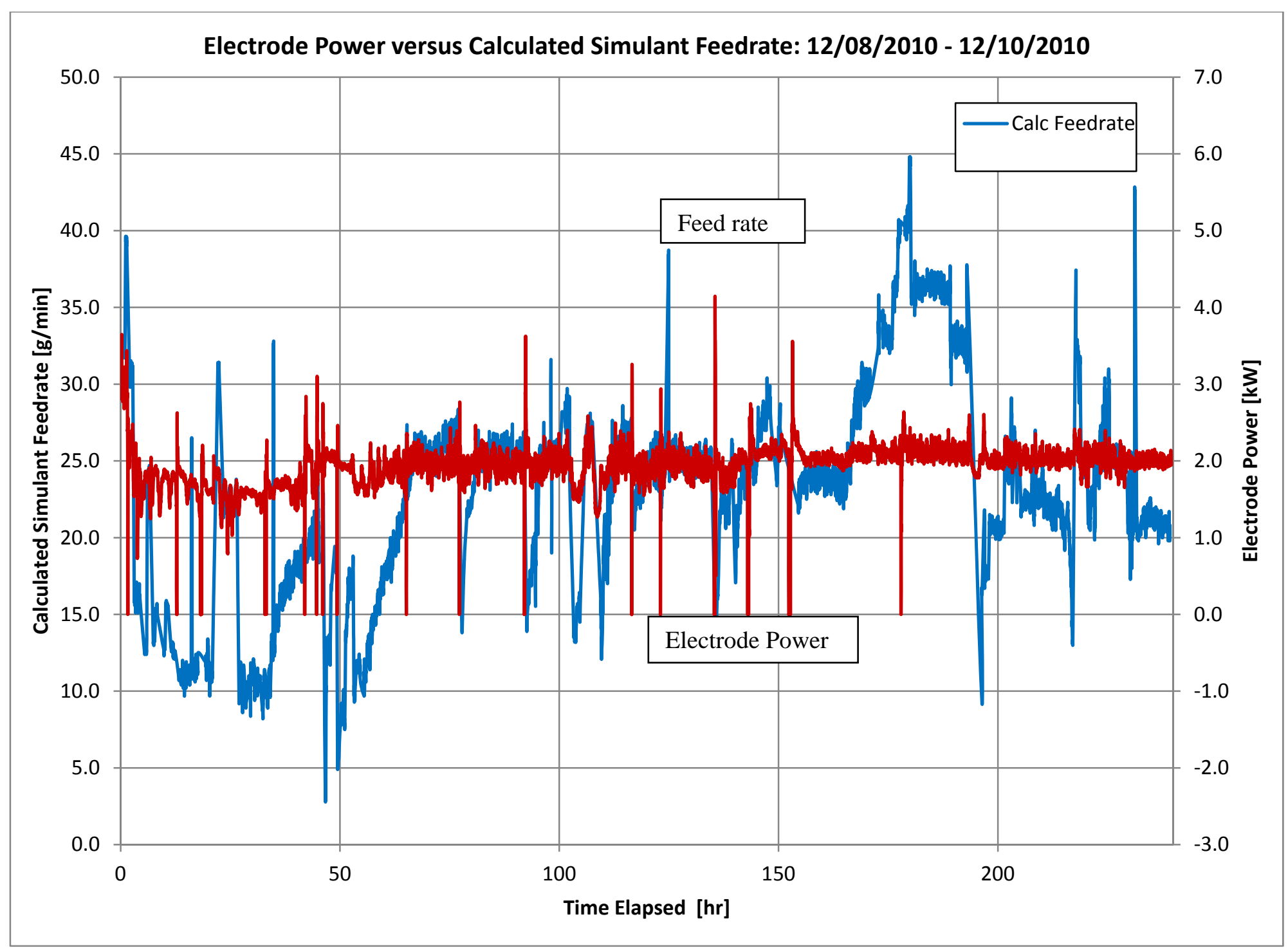

Figure 6.2. RSM Feed Rate and Electrode Power 


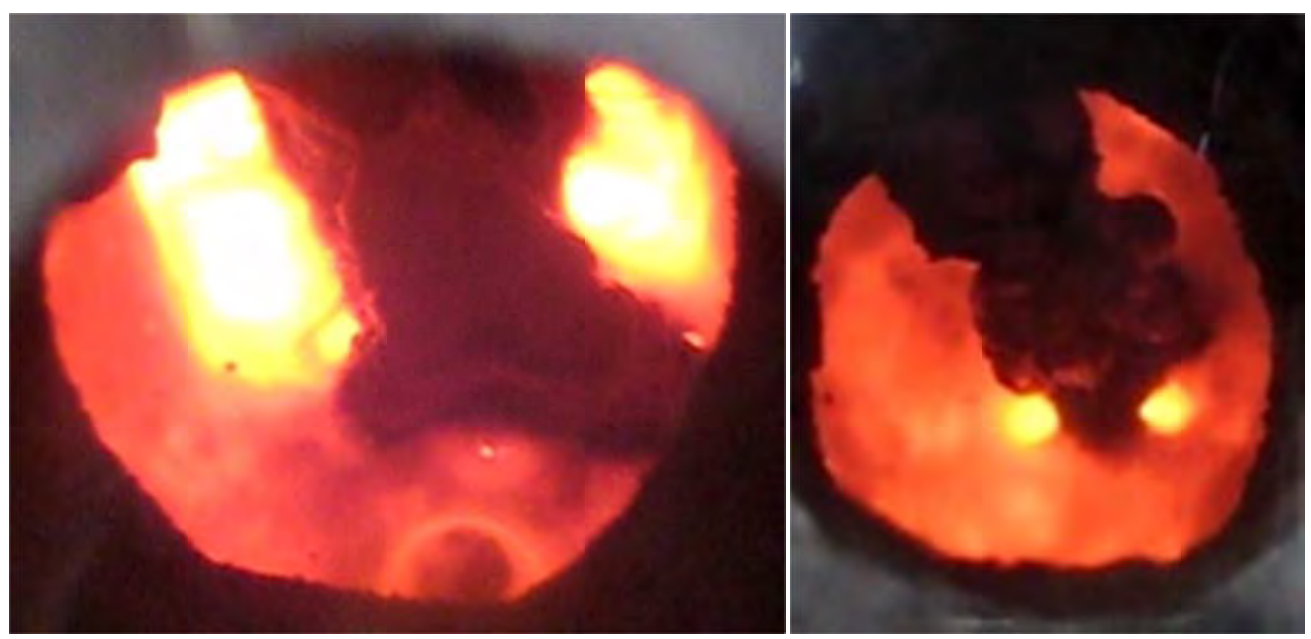

Figure 6.3. Small Cold Cap (left). Dark perimeter is 'cold' foam. Feed nozzle is top center of photo.

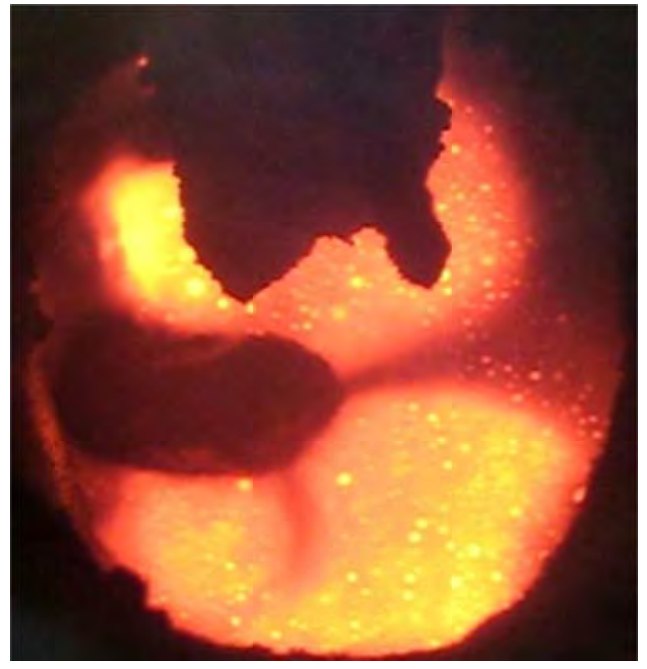

Figure 6.4. Segment 3 Molten Glass Surface

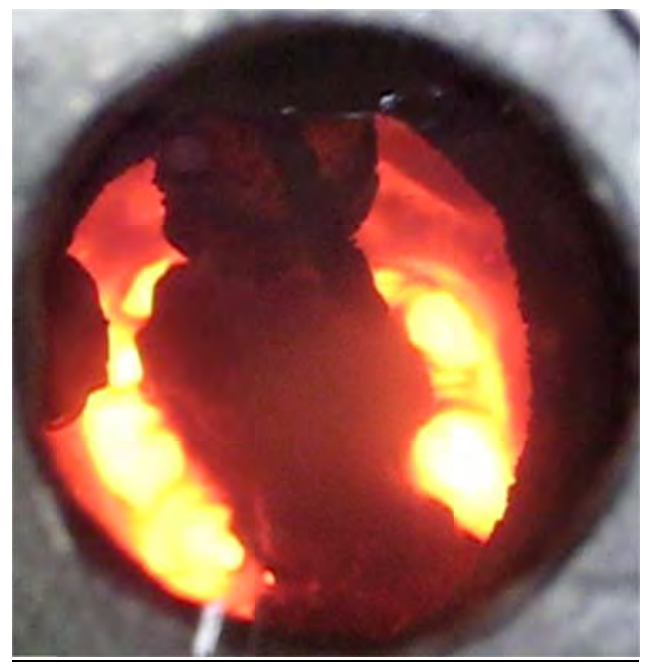

Figure 6.5. Large, Highly Mobile Cold Cap in Segment 3 
Segment 5, the final segment (no sugar, bubbler on), was initiated on December 8, 2010 at 1348 hrs. Glass was produced under similar conditions to those in Segment 2 (no sugar, bubbler on) except for a longer duration and a slightly higher bubbling rate. The bubbling rate averaged about 1.5 liters/min but the feed rate was still lower than the rate achieved in Segment 4 when bubbling and sugar were used. The glass production rate was similar to Segment 2 and may be slightly higher because there were fewer feed outages. The average feed rate for Segment 5 was $0.82 \mathrm{~L} / \mathrm{hr}$ and the glass production rate was $0.57 \mathrm{~kg} / \mathrm{hr}$ (754 kg/m²/day).

\subsection{Melter System Inspection}

At the conclusion of the test, the melter and exhaust lines were inspected. The melter electrodes and bubbler tube were removed from the melt while the glass was hot. After the glass cooled, the melter lid and first section of the exhaust line were disassembled. The electrodes looked discolored but a significant amount of metal did not appear to be removed. The edges of the electrodes were sharp (as shown in Figure 6.6). Green material on the electrodes came from dragging the electrodes along the side of the melter during removal. In addition, some glass was still attached to the electrode. Overall, the electrodes appeared to be in relatively good condition. The bubbler tube, which was made from thin wall Inconel $^{\mathrm{TM}} 625$ tubing, was heavily oxidized but was still intact and still had some ductility. Inspection of the melter lid showed that a large amount of entrained material adhered to the underside and to the exhaust piping. Some deposits on the lid appeared to be volatilized material as indicated by the different color on the outer most deposits while the inner deposits were mostly brown. The material was not identified from the X-ray diffraction (XRD) analyses and the ICP did not analyze for Ni as it was used in the sample fusion. The composition of the deposits is provided in Table 6.2. The material is enriched in $\mathrm{S}$ and depleted in $\mathrm{Zn}, \mathrm{Na}$, and $\mathrm{P}$, as compared to the glass composition. The ratio of the Na and $\mathrm{P}$ indicates there may be significant amounts of sodium phosphate. The deposits are probably also enriched in $\mathrm{Cl}$ and $\mathrm{F}$ like the scrubber solutions. The exhaust gas scrubber solution was highly enriched in sulfates, nitrates, $\mathrm{Cl}, \mathrm{F}$, and I. The anions made an acidic scrub solution with a $\mathrm{pH}$ less than 1 . The most abundant cations in the scrub solution were $\mathrm{Na}$ and $\mathrm{P}$ with a ratio that indicates sodium phosphate compounds may have been released from the melter.

The overall operation of the melter was steady with the exception of the bubbler rate which drifted up during the test and was higher than desired for the small melter. The high bubbler flow rates probably caused most of the particulate entrainment. The bubbler flow rate for the tests varied as shown in Figure 6.7. Optimizing the bubbler flow would likely improve long-term operation.

The Inconel ${ }^{\mathrm{TM}} 690$ pour spout downcomer was missing at the end of the test. However is appears there was a small seal weld connecting it to the rest of the pour spout that probably failed. The rest of the pour spout was heavily oxidized but in relatively good condition.

A core of the melt glass left in the Monofrax K-3 crucible was removed from the melter at the end of the test to inspect for crystals or reduced metals. No large quantities of crystals or reduced metals were observed. 


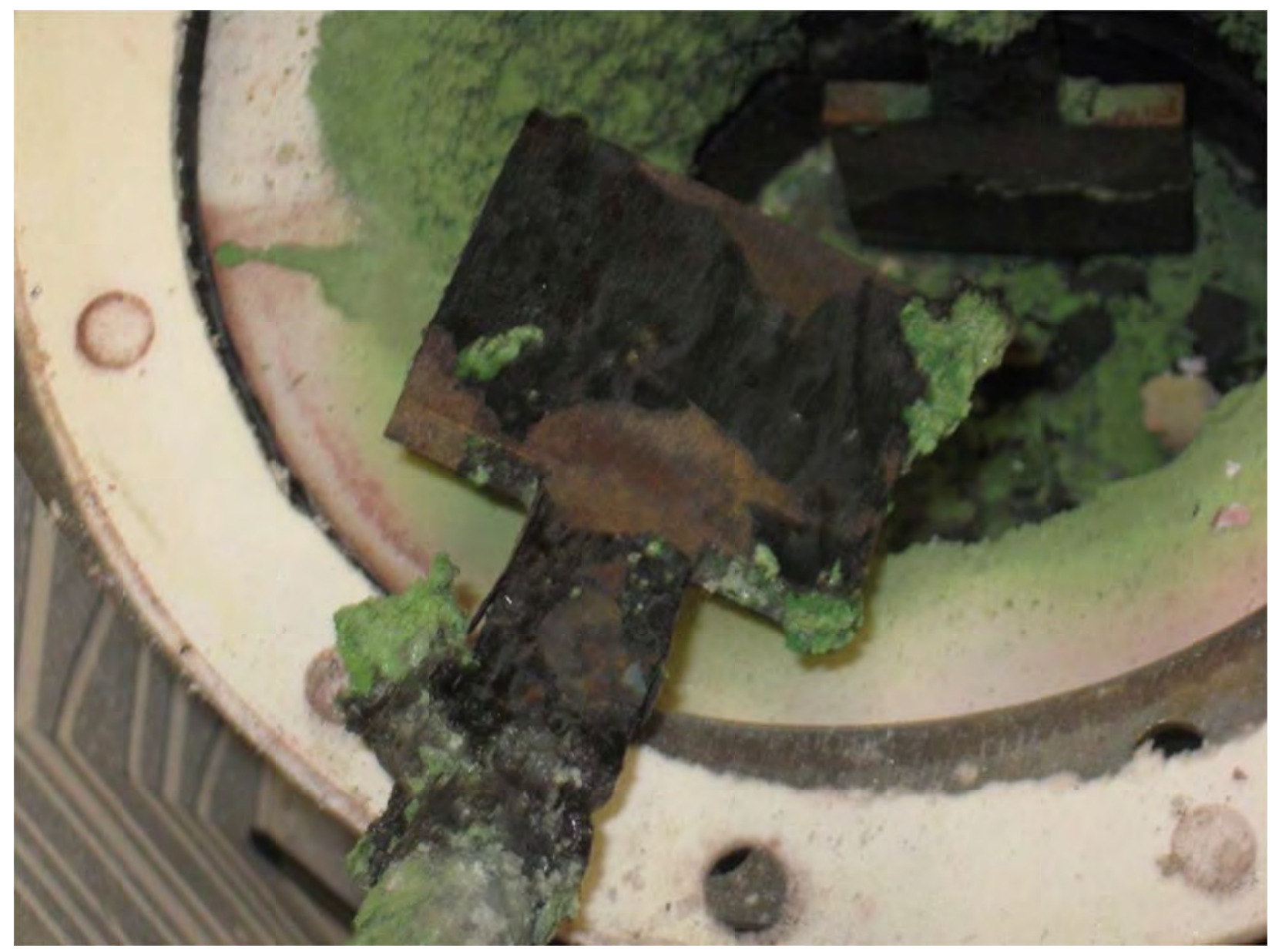

Figure 6.6. Melter Electrodes Pulled From the Glass Melt

Table 6.2. Plenum and Exhaust Line Deposit Composition

\begin{tabular}{lccc}
\hline Compound & $\begin{array}{c}\text { Melter Lid } \\
\text { wt\% }\end{array}$ & $\begin{array}{c}\text { Offgas Pipe } \\
\text { wt\% }\end{array}$ & $\begin{array}{c}\text { Green Powder } \\
\text { Inside Melter } \\
\text { wt\% }\end{array}$ \\
\hline $\mathrm{Al2O} 3$ & 13.91 & 6.42 & 9.43 \\
$\mathrm{Bi} 2 \mathrm{O} 3$ & 0.78 & 0.96 & 1.54 \\
$\mathrm{Cr} 2 \mathrm{O} 3$ & 1.86 & 1.31 & 2.02 \\
$\mathrm{Fe} 2 \mathrm{O} 3$ & 6.64 & 3.21 & 5.19 \\
$\mathrm{Na} 2 \mathrm{O}$ & 8.80 & 9.57 & 13.74 \\
$\mathrm{P} 2 \mathrm{O} 5$ & 14.05 & 17.97 & 27.73 \\
$\mathrm{Re} 2 \mathrm{O} 7$ & 0.00 & 0.00 & 0.00 \\
$\mathrm{SO} 4$ & 27.39 & 28.71 & 13.80 \\
$\mathrm{SiO} 2$ & 5.13 & 2.99 & 4.41 \\
ZnO & 1.41 & 1.53 & 2.38 \\
Other & 0.89 & 0.35 & 0.33 \\
Total mass: & $51.15 \mathrm{~g}$ & $50.06 \mathrm{~g}$ & $4.96 \mathrm{~g}$ \\
\hline
\end{tabular}




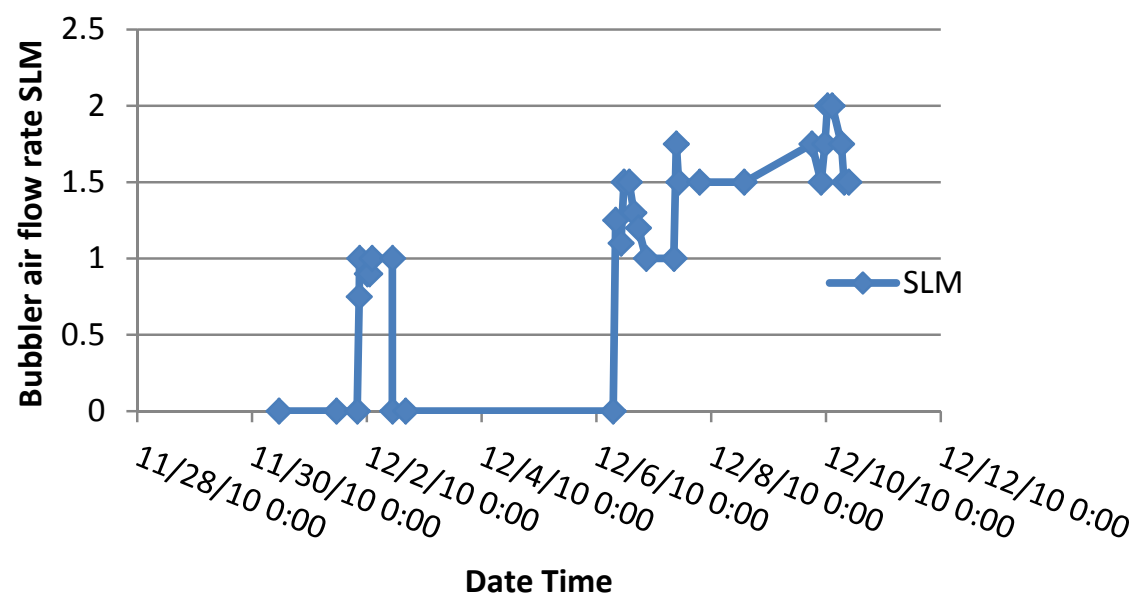

Figure 6.7. Bubbler Flow Rates During the Test

\subsection{Operational Summary}

The RSM test segments were successful in providing glass samples and basic operational data for the iron phosphate glass feed. Optimum steady state processing may not have been attained in some cases, but system optimization was not a priority in this initial test. Additional testing will be required to optimize operating conditions. 


\subsection{Data Collection and Sample Collection/Analysis}

Characterization activities supporting experimental test objectives included the collection of operational, monitoring, and control data as well as process stream compositional information.

\subsection{Data Collection and Process Controls}

The collection of process operational and control data was performed primarily by the RSM data acquisition and control (DAC) system, which monitors, controls, and electronically logs key system variables. Process data not electronically logged by this system and selected parameters of greatest interest were recorded manually on operator datasheets.

Table 7.1 identifies the process information that was electronically logged by the RSM DAC and/or manually logged on RSM operation datasheets. The data documented important operational conditions associated with the melter, its offgas system, feed, glass and secondary waste streams. Routine datasheets from the operating procedure were filled out on an hourly basis throughout the duration of testing.

Table 7.1. RSM Process Data Electronically (1-s) or Manually (1-hr) Logged

\begin{tabular}{|c|c|c|c|c|}
\hline Parameter & Units & Range & Electronic Log & Manual Log \\
\hline Melt temperature (T1, control, T2, backup) & ${ }^{\circ} \mathrm{C}$ & 1000 to 1050 & $\mathrm{X}$ & $\mathrm{X}$ \\
\hline Plenum temperature & ${ }^{\circ} \mathrm{C}$ & 200 to 500 & $\mathrm{X}$ & $\mathrm{X}$ \\
\hline Feed pump setting & $\%$ & & $\mathrm{X}$ & $\mathrm{X}$ \\
\hline Cold cap coverage & $\%$ & $>75$ & --- & $\mathrm{X}$ \\
\hline Number of vents & \# & & --- & $\mathrm{X}$ \\
\hline Electrode potential & volts & 10 to 100 & $\mathrm{X}$ & $\mathrm{X}$ \\
\hline Electrode current & amps & $<200$ & $\mathrm{X}$ & $\mathrm{X}$ \\
\hline Electrode power & $\mathrm{kW}$ & & $\mathrm{X}$ & $\mathrm{X}$ \\
\hline Melt (electrode) setpoint temperature & ${ }^{\circ} \mathrm{C}$ & & $\mathrm{X}$ & $\mathrm{X}$ \\
\hline Kiln power & $\mathrm{kW}$ & & $\mathrm{X}$ & $\mathrm{X}$ \\
\hline Kiln temperature setpoint & ${ }^{\circ} \mathrm{C}$ & & $\mathrm{X}$ & $\mathrm{X}$ \\
\hline Kiln actual (middle) temperature & ${ }^{\circ} \mathrm{C}$ & & $\mathrm{X}$ & $\mathrm{X}$ \\
\hline Kiln control mode & A or $\mathrm{M}$ & & $\mathrm{X}$ & $\mathrm{X}$ \\
\hline Discharge can power & KW & & $\mathrm{X}$ & $\mathrm{X}$ \\
\hline Discharge can temperature setpoint & ${ }^{\circ} \mathrm{C}$ & & $\mathrm{X}$ & $\mathrm{X}$ \\
\hline Discharge can actual temperature & ${ }^{\circ} \mathrm{C}$ & & $\mathrm{X}$ & $\mathrm{X}$ \\
\hline Discharge can power output & $\%$ & & $\mathrm{X}$ & $\mathrm{X}$ \\
\hline Pour spout heater setpoint & ${ }^{\circ} \mathrm{C}$ & & $\mathrm{X}$ & $\mathrm{X}$ \\
\hline Pour spout heater temperature & ${ }^{\circ} \mathrm{C}$ & & $\mathrm{X}$ & $\mathrm{X}$ \\
\hline Pour spout heater power output & $\%$ & & $\mathrm{X}$ & $\mathrm{X}$ \\
\hline Feed nozzle cooling flow & gpm & 0.5 & --- & $\mathrm{X}$ \\
\hline Film cooler air flowrate (Indicated) & scfm & 1 to 10 & --- & $\mathrm{X}$ \\
\hline Film cooler back pressure & psi & 0 to 60 & --- & $\mathrm{X}$ \\
\hline Melter vacuum-magnehelic & in. $\mathrm{H}_{2} \mathrm{O}$ & 0.1 to 2.0 & --- & $X$ \\
\hline
\end{tabular}


Table 7.1. (contd)

\begin{tabular}{lcccc}
\hline \multicolumn{1}{c}{ Parameter } & Units & Range & Electronic Log & Manual Log \\
\hline EVS heat exchanger cooling flow & gpm & 1 to 5 & --- & $\mathrm{X}$ \\
EVS scrub tank volume & liters & 20 to 220 & --- & $\mathrm{X}$ \\
EVS nozzle pressure & $\mathrm{psi}$ & 50 to 55 & --- & $\mathrm{X}$ \\
Offgas temperature & ${ }^{\circ} \mathrm{C}$ & $<250$ & $\mathrm{X}$ & $\mathrm{X}$ \\
Post-EVS offgas temperature & ${ }^{\circ} \mathrm{C}$ & $<50$ & $\mathrm{X}$ & $\mathrm{X}$ \\
Scrub liquid EVS inlet temperature & ${ }^{\circ} \mathrm{C}$ & $<50$ & $\mathrm{X}$ & $\mathrm{X}$ \\
Heat exchanger temperature & ${ }^{\circ} \mathrm{C}$ & $<50$ & $\mathrm{X}$ & $\mathrm{X}$ \\
Feed line pressure & $\mathrm{psi}$ & & $\mathrm{X}$ & $\mathrm{X}$ \\
Feed tank weight & $\mathrm{Kg}$ & decreasing & $\mathrm{X}$ & $\mathrm{X}$ \\
Pour spout temperature & ${ }^{\circ} \mathrm{C}$ & 900 to 1000 & $\mathrm{X}$ & $\mathrm{X}$ \\
Discharge can temperature & ${ }^{\circ} \mathrm{C}$ & 700 to 850 & $\mathrm{X}$ & $\mathrm{X}$ \\
Glass scale & $\mathrm{Kg}$ & $<10$ & --- & $\mathrm{X}$ \\
\hline
\end{tabular}

Visual observations of the operating behavior of the feed system, melter, and offgas system were also recorded in the RSM logbook. Processing anomalies involving the cold cap, glass conditions, offgas behavior, corrosion, or salt formation were noted. All feed rate adjustments, operational problems, and optimizations activities were also recorded.

At the completion of testing, the melter system was shut down according to procedure. The melter electrodes, feed-nozzle, and offgas system were visually examined for any wear, pitting, or corrosion. Offgas debris in segments of the melter/EVS offgas jumper was measured and subsequently combined, homogenized, and analyzed. Neither the melter operation nor the glass product characteristics suggested the presence of a separate metal phase; however, the RSM melt cavity was only examined in one location for possible accumulation of reduced metals.

\subsection{Process Sample Collection and Analysis}

The routine sampling of the feed, glass, and secondary waste streams was conducted based on instructions in the test procedure. The melter feed distribution panel allowed for direct sampling of the melter feed stream. Glass samples were collected from the melter pour spout stream using a graphite boat. Since the newly formed glass bar could shatter and create a sharp projectile hazard, glass samples were shielded while cooling. EVS condensate drain samples were directly extracted from valves on the condensate recirculation line. The HEME run off was manually recycled back to the EVS recirculation tank. The analysis of the condensate samples was performed by separating the solids and the supernate to aid in characterization of the materials.

Process samples that were collected for analysis included the feed slurry, glass product, offgas line accretions, and secondary offgas system waste streams, including EVS scrubbing liquid, undissolved solids (UDS), and HEME run-off. In general, process samples (except for offgas line deposits and the EVS UDS, which was only collected at the conclusion of testing) were collected at least once per day and for every identified "stable" operating condition. Sample analyses were conducted to characterize the quantities, compositions, and properties of these process streams. 
Glass sample analyses included not only the elemental composition, but also leachability and density. Leachability was measured using the Product Consistency Test PCT and VHT tests.

Although feed, glass, offgas waste stream, and pipe accretion samples were collected according to the frequency indicated; only those samples considered to be most representative of selected test conditions were analyzed. Furthermore, not all analytical samples of a particular type were subjected to identical analytical schedules. For example, some of the glass samples that were analyzed for elemental composition were not analyzed for leachability or other properties. However, at least one glass and two EVS samples were analyzed for each test segment.

Sample Identification: Process stream samples were collected as detailed in the test instruction ${ }^{1}$. All samples were identified according to the following unique sequential labeling scheme starting with RSM-FEP-001 and logged with the following descriptive information.

- Date \& military time

- Sample description (e.g., Feed, Condensate, Glass Sample)

- Initials of operations staff obtaining sample.

This information was recorded on sample log sheets and all sample containers were similarly labeled.

\subsection{Sample Analysis Procedures and Equipment}

Process and offgas samples were analyzed, as applicable, for elemental composition, leachability, and density. Some analyses were contemporaneous with test operations, while most others incurred delays of several hours or days, depending on the kind of analysis performed, the sample preparation required prior to analysis, and the location of the analytical equipment. Table 7.2 briefly describes the different analyses included in this test program.

Table 7.2. Sample Analysis Methods for Process and Offgas Samples

\begin{tabular}{|c|c|c|c|}
\hline Analysis & Sample matrix & Analysis Method & Analysis Description \\
\hline Cations & Solid or liquid & ICP for metals & $\begin{array}{l}\text { Analysis of total amount of element, regardless of } \\
\text { speciation }\end{array}$ \\
\hline Anions & Solid & X-ray fluorescence & $\mathrm{Cl}^{-}, \mathrm{F}^{-}, \mathrm{I}^{-}$ \\
\hline & Liquid & IC, Specific ion electrode & $\mathrm{Cl}^{-}, \mathrm{F}^{-}, \mathrm{I}^{-}$, nitrate, nitrite, and phosphate \\
\hline Leachability & & PCT and VHT & \\
\hline Density & Solid & --- & Gas with a known mass or liquid displacement \\
\hline
\end{tabular}

As mentioned in the section above, many samples were taken to characterize the tests as shown in Table 7.3 and Table 7.4.

\footnotetext{
${ }^{1}$ Sevigny GJ. 2010. “Test Instruction: TP-511EM31-2010 Iron Phosphate Glass Containing Hanford Waste Simulant”. Pacific Northwest National Laboratory.
} 
Table 7.3. Glass Sample List

\begin{tabular}{lcrlllll}
\hline ID & Date & Time & Material & & Analyses & \\
\hline RSM-FEP-7 & $12 / 1 / 2010$ & 1052 & Glass & Elem & & \\
RSM-FEP-10 & & & Glass & & PCT c & VHT, XRD \\
RSM-FEP-12 & $12 / 2 / 2010$ & 340 & Glass & Elem & PCT q & \\
RSM-FEP-18 & $12 / 3 / 2010$ & 137 & Glass & Elem & PCT c & \\
RSM-FEP-24 & $12 / 3 / 2010$ & 1730 & Glass & Elem & PCT cq & \\
RSM-FEP-26 & $12 / 4 / 2010$ & 245 & Glass & & & VHT \\
RSM-FEP-30 & $12 / 4 / 2010$ & 1407 & Glass & Elem & PCT q & \\
RSM-FEP-31 & $12 / 4 / 2010$ & 1407 & Glass & & & VHT \\
RSM-FEP-34 & $12 / 4 / 2010$ & 1621 & Glass & Elem & & \\
RSM-FEP-37 & $12 / 4 / 2010$ & 2110 & Glass & & & VHT \\
RSM-FEP-38 & $12 / 5 / 2010$ & 120 & Glass & Elem & PCT cq & \\
RSM-FEP-43 & $12 / 5 / 2010$ & 1820 & Glass & & & VHT \\
RSM-FEP-48 & $12 / 6 / 2010$ & 1400 & Glass & Elem & PCT c & \\
RSM-FEP-54 & $12 / 7 / 2010$ & 1037 & Glass & Elem & PCT q & \\
RSM-FEP-59 & $12 / 7 / 2010$ & 2345 & Glass & Elem & PCT cq & \\
RSM-FEP-61 & $12 / 9 / 2010$ & 1058 & Glass & Elem & PCT cq & \\
RSM-FEP-63 & $12 / 8 / 2010$ & 1030 & Glass & Elem & PCT c & \\
RSM-FEP-65 & $12 / 8 / 2010$ & 2026 & Glass & Elem & PCT cq & \\
RSM-FEP-68 & $12 / 9 / 2010$ & 11 & Glass & Elem & PCT cq & \\
\hline RSM-FEP-70 & $12 / 9 / 2010$ & 1058 & Glass & & & VHT \\
RSM-FEP-72 & $12 / 9 / 2010$ & 1723 & Glass & Elem & PCT c & \\
RSM-FEP-74 & $12 / 10 / 2010$ & 545 & Glass & Elem & PCT cq & \\
RSM-FEP-76 & $12 / 10 / 2010$ & 930 & Glass & Elem & PCT c & \\
\hline
\end{tabular}

Table 7.4. Offgas Samples

\begin{tabular}{ccc}
\hline ID & Date & Time \\
\hline RSM-FEP-2 & $11 / 30 / 2010$ & 717 \\
RSM-FEP-17 & $12 / 2 / 2010$ & 1620 \\
RSM-FEP-28 & $12 / 4 / 2010$ & 723 \\
RSM-FEP-45 & $12 / 5 / 2010$ & 2323 \\
RSM-FEP-51 & $12 / 6 / 2010$ & 2207 \\
RSM-FEP-58 & $12 / 7 / 2010$ & 2121 \\
RSM-FEP-66 & $12 / 8 / 2010$ & 2020 \\
RSM-FEP-71 & $12 / 9 / 2010$ & 1720 \\
RSM-FEP-78 & $12 / 10 / 2010$ & 1050 \\
\hline
\end{tabular}

\subsection{Analyses of Offgas Condensate}

Scrubber solutions were analyzed with inductively coupled plasma-atomic emission spectroscopy (ICP-AES) for Al, Bi, B, Ca, Cr, Fe, K, La, Na, Ni, P, S, Si, Zn and Zr, and with inductively coupled plasma-mass spectrometry (ICP-MS) for Cs, I and Re. Prior to measurement, the solutions were filtered to remove any particles that were analyzed separately. Table 7.5 below represents a composite of the soluble and insoluble sample analyses. 
Table 7.5. Condensate Analysis (wt\%)

\begin{tabular}{|c|c|c|c|c|c|c|c|c|c|c|c|}
\hline Sample ID & $\mathrm{Al}_{2} \mathrm{O}_{3}$ & $\mathrm{~B}_{2} \mathrm{O}_{3}$ & $\mathrm{Bi}_{2} \mathrm{O}_{3}$ & $\mathrm{C}_{2} \mathrm{O}_{4}$ & $\mathrm{CaO}$ & $\mathrm{Cl}$ & $\mathrm{Cr}_{2} \mathrm{O}_{3}$ & $\mathrm{Cs}_{2} \mathrm{O}$ & $\mathrm{F}$ & $\mathrm{Fe}_{2} \mathrm{O}_{3}$ & I \\
\hline RSM-FEP-2 & 0.00 & $<$ Detect & $<$ Detect & $<$ Detect & 0.00 & $<$ Detect & 0.00 & 0.0000 & $<$ Detect & 0.00 & 0.0003 \\
\hline RSM-FEP-17 & 0.01 & 0.00 & 0.00 & $<$ Detect & 0.00 & $<$ Detect & 0.00 & 0.0003 & 0.01 & 0.00 & 0.0005 \\
\hline RSM-FEP-28 & 0.01 & 0.00 & 0.00 & $<$ Detect & 0.01 & $<$ Detect & 0.00 & 0.0005 & 0.02 & 0.00 & 0.0012 \\
\hline RSM-FEP-42 & 0.02 & 0.00 & 0.00 & $<$ Detect & 0.01 & $<$ Detect & 0.00 & 0.0006 & 0.02 & 0.00 & 0.0019 \\
\hline RSM-FEP-51 & 0.02 & 0.00 & 0.00 & $<$ Detect & 0.01 & $<$ Detect & 0.00 & 0.0007 & 0.02 & 0.01 & 0.0028 \\
\hline RSM-FEP-58 & 0.02 & 0.00 & 0.00 & $<$ Detect & 0.01 & $<$ Detect & 0.00 & 0.0009 & 0.02 & 0.01 & 0.0029 \\
\hline RSM-FEP-66 & 0.02 & 0.00 & 0.00 & $<$ Detect & 0.01 & 0.01 & 0.00 & 0.0010 & 0.03 & 0.01 & 0.0032 \\
\hline RSM-FEP-78 & 0.02 & 0.00 & 0.00 & $<$ Detect & 0.01 & 0.02 & 0.00 & 0.0097 & 0.03 & 0.01 & 0.0035 \\
\hline Sample ID & $\mathrm{K}_{2} \mathrm{O}$ & $\mathrm{La}_{2} \mathrm{O}_{3}$ & $\mathrm{NO}_{2}$ & $\mathrm{NO}_{3}$ & $\mathrm{Na}_{2} \mathrm{O}$ & $\mathrm{P}_{2} \mathrm{O}_{5}$ & $\mathrm{Re}_{2} \mathrm{O}_{7}$ & $\mathrm{SO}_{3}$ & $\mathrm{SiO}_{2}$ & $\mathrm{ZnO}$ & $\mathrm{ZrO}_{2}$ \\
\hline RSM-FEP-2 & 0.00 & $<$ Detect & $<$ Detect & 0.02 & 0.00 & $<$ Detect & 0.0001 & 0.02 & 0.00 & 0.00 & 0.00 \\
\hline RSM-FEP-17 & 0.00 & 0.00 & $<$ Detect & 0.37 & 0.03 & 0.03 & 0.0010 & 0.23 & 0.00 & 0.01 & 0.00 \\
\hline RSM-FEP-28 & 0.00 & 0.00 & $<$ Detect & 0.35 & 0.05 & 0.03 & 0.0017 & 0.72 & 0.00 & 0.01 & 0.00 \\
\hline RSM-FEP-42 & 0.00 & 0.00 & $<$ Detect & 0.42 & 0.05 & 0.05 & 0.0022 & 1.05 & 0.00 & 0.01 & 0.00 \\
\hline RSM-FEP-51 & 0.00 & 0.00 & $<$ Detect & 0.42 & 0.06 & 0.05 & 0.0026 & 1.04 & 0.00 & 0.01 & 0.00 \\
\hline RSM-FEP-58 & 0.00 & 0.00 & $<$ Detect & 0.41 & 0.07 & 0.05 & 0.0032 & 1.42 & 0.00 & 0.01 & 0.00 \\
\hline RSM-FEP-66 & 0.00 & 0.00 & $<$ Detect & 0.40 & 0.07 & 0.06 & 0.0036 & 1.57 & 0.00 & 0.01 & 0.00 \\
\hline RSM-FEP-78 & 0.00 & 0.00 & $<$ Detect & 0.54 & 0.08 & 0.06 & 0.0041 & 1.66 & 0.00 & 0.02 & 0.00 \\
\hline
\end{tabular}




\subsection{Corrosion Observations}

The electrodes were visually examined after the test. One thin section was cut from the side of the electrode and examined with an optical microscope and a scanning electron microscopes (SEM). One of the electrodes showed corrosion (Figure 7.1), with some affected areas increasing in depth over the length of the electrode to $\sim 5.4 \mathrm{~mm}$ at the maximum etch depth. A corrosion rate based on the measured values suggests losses of $<2.5 \mathrm{~mm}$ /year. The SEM (Figure 7.2) examination shows areas enriched in $\mathrm{Al}, \mathrm{Cu}, \mathrm{P}$, and Si for both the low and high regions (Figure 7.3). The differences between before and after measurements of the electrodes were very small, with some being larger after the test. The maximum corrosion rate based on electrode measurement before and after the test was less than 13 mils/yr.

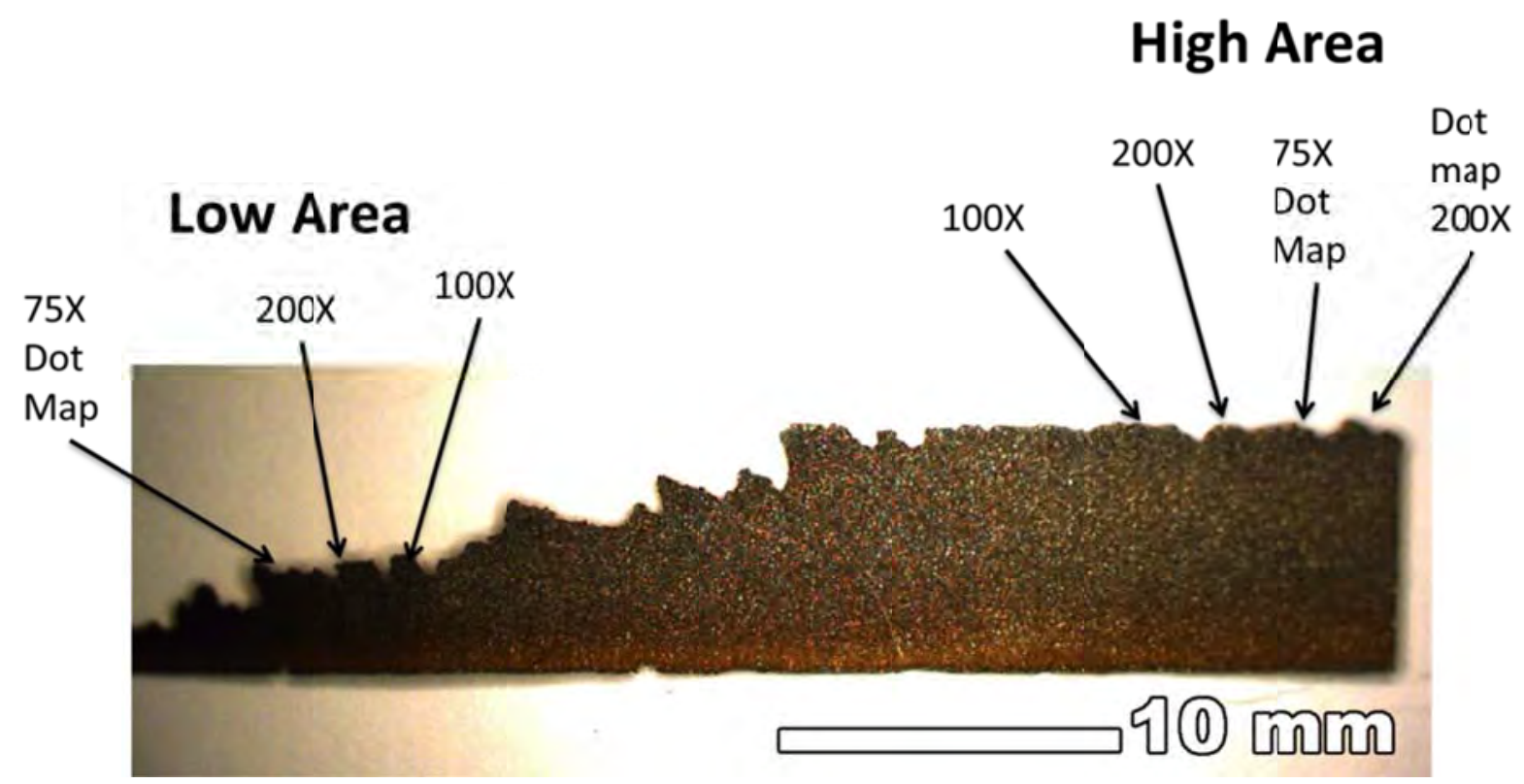

Figure 7.1. Optical Micrograph of an Electrode Thin Section. This sample was used for SEM analysis as well. 

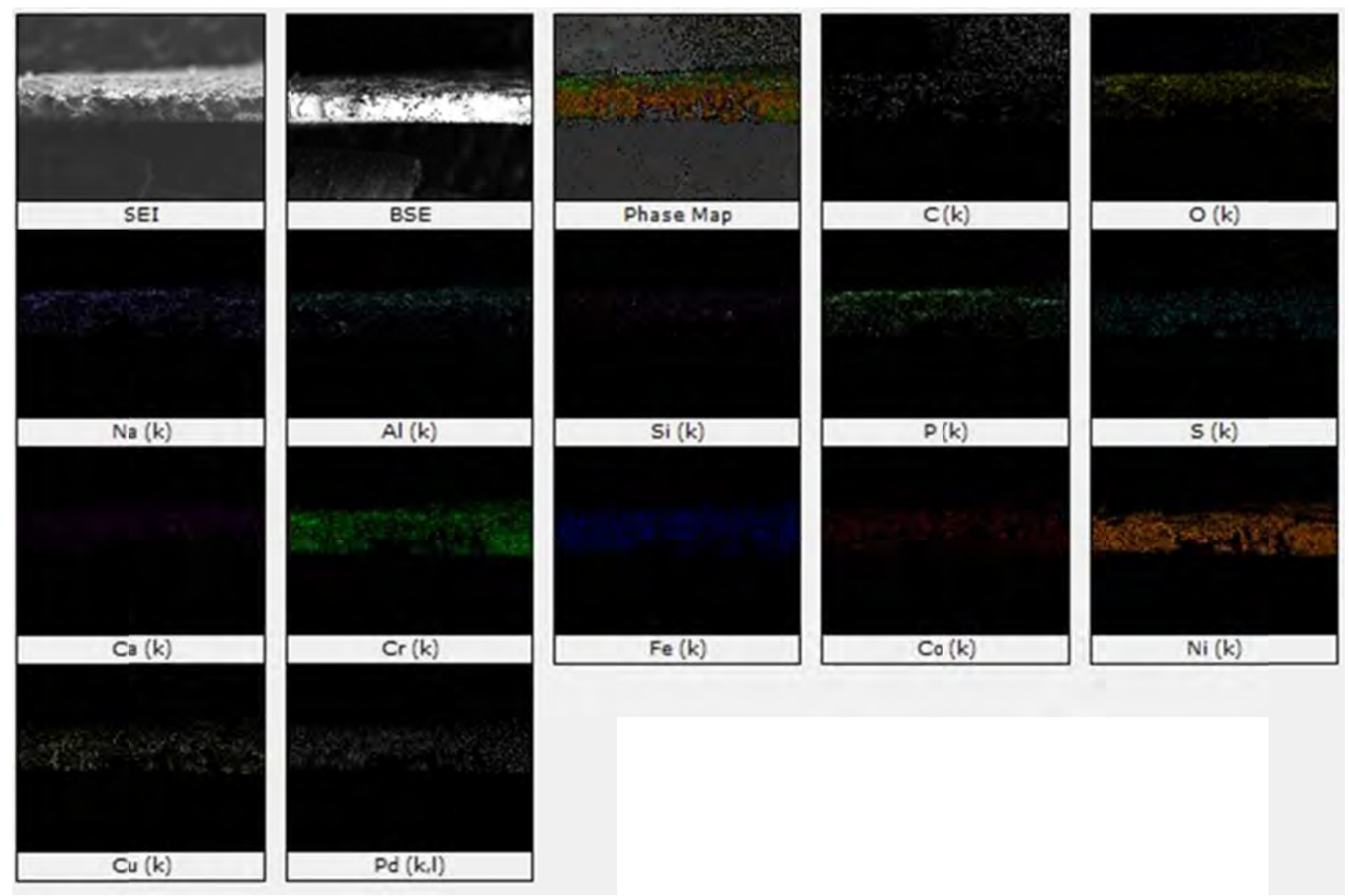

$S(k)$

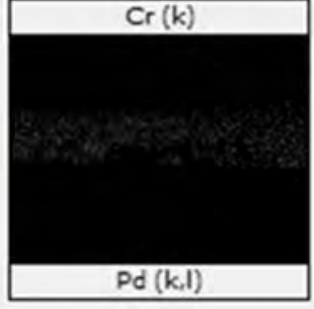

$\mathrm{Fe}(\mathrm{k})$

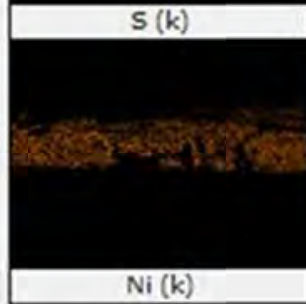

Figure 7.2. SEM High, 75X Dot Map of Electrode

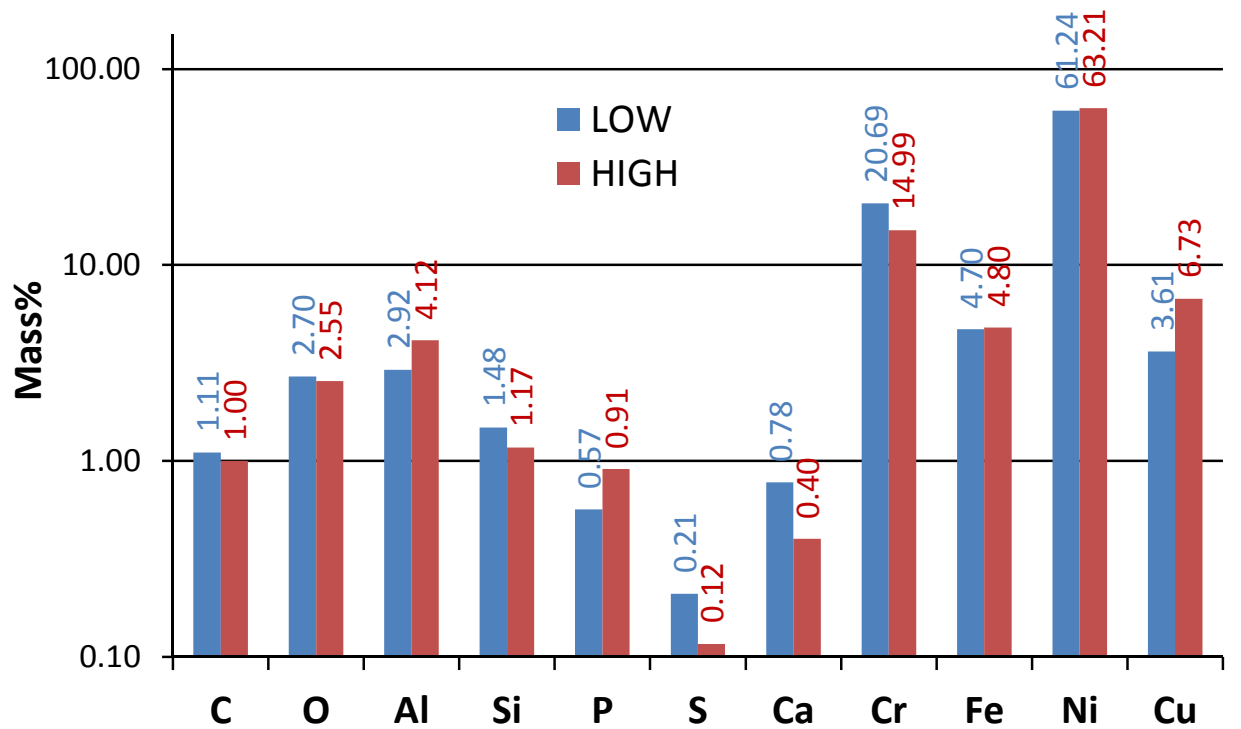

Figure 7.3. EDS Results From Low and High Regions of the Electrode Showing the Mass \% of Each Constituent 



\subsection{Glass Characterization}

\subsection{Analyses of Glass}

To confirm that the fabricated glasses met the target composition, SRNL took a representative sample from each glass that was submitted for chemical analysis; results are summarized in Table 8.1. Samples were prepared by the following dissolutions: lithium metaborate, peroxide fusion, mixed acid, and inverse aqua regia. ICP-AES ${ }^{1}$ was used to analyze the resulting dissolutions for $\mathrm{Al}, \mathrm{Bi}, \mathrm{B}, \mathrm{Ca}, \mathrm{Cr}, \mathrm{Fe}, \mathrm{K}$, $\mathrm{La}, \mathrm{Na}, \mathrm{Ni}, \mathrm{P}, \mathrm{S}, \mathrm{Si}, \mathrm{Zn}$, and $\mathrm{Zr}$ concentrations. ICP-MS ${ }^{2}$ was used to analyze the dissolutions for $\mathrm{Cs}$ and Re. A low level waste reference, approved reference material (ARM), and standard solutions of Cs and Re were included in the analyses to assess the performance of the ICP-AES and ICP-MS.

Representative solid glass samples were analyzed for iodine with neutron activation analysis.,4 Elemental concentrations were converted to oxide concentrations by multiplying the values for each element by the gravimetric factor for the corresponding oxide.

\footnotetext{
${ }^{1}$ Varian Vista AX - ICP-AES

${ }^{2}$ Fisons PQ-II

${ }^{3}$ Californium source

${ }^{4}$ Canberra LABSOCS, Model GC13023
} 
Table 8.1. Glass Sample Analyses (wt\%)

\begin{tabular}{|c|c|c|c|c|c|c|c|c|c|c|c|c|c|c|c|c|c|}
\hline Sample ID & $\mathrm{Al}_{2} \mathrm{O}_{3}$ & $\mathrm{~B}_{2} \mathrm{O}_{3}$ & $\mathrm{Bi}_{2} \mathrm{O}_{3}$ & $\mathrm{CaO}$ & $\mathrm{Cr}_{2} \mathrm{O}_{3}$ & $\mathrm{Cs}_{2} \mathrm{O}$ & $\mathrm{Fe}_{2} \mathrm{O}_{3}$ & I & $\mathrm{K}_{2} \mathrm{O}$ & $\mathrm{La}_{2} \mathrm{O}_{3}$ & $\mathrm{Na}_{2} \mathrm{O}$ & $\mathrm{P}_{2} \mathrm{O}_{5}$ & $\mathrm{Re}_{2} \mathrm{O}_{7}$ & $\mathrm{SiO}_{2}$ & $\mathrm{SO}_{3}$ & $\mathrm{ZnO}$ & $\mathrm{ZrO}_{2}$ \\
\hline RSM-FEP-7 & 13.74 & $<$ Detect & 1.77 & 1.15 & 2.11 & 0.13 & 6.80 & $<$ Detect & 1.06 & 0.55 & 20.72 & 37.56 & 0.01 & 5.95 & 3.43 & 3.51 & 0.44 \\
\hline RSM-FEP-12 & 13.85 & $<$ Detect & 1.84 & 1.14 & 2.88 & 0.13 & 7.14 & $<$ Detect & 1.07 & 0.59 & 20.59 & 37.67 & 0.01 & 5.97 & 2.80 & 3.41 & 0.74 \\
\hline RSM-FEP-18 & 14.17 & $<$ Detect & 1.94 & 1.17 & 2.71 & 0.14 & 7.30 & $<$ Detect & 1.21 & 0.61 & 20.52 & 39.50 & 0.02 & 6.16 & 1.08 & 3.58 & 0.78 \\
\hline RSM-FEP-24 & 14.15 & $<$ Detect & 1.96 & 1.22 & 2.73 & & 7.30 & $<$ Detect & 1.18 & 0.62 & 20.66 & 39.39 & & 6.31 & 1.13 & 3.60 & 0.86 \\
\hline RSM-FEP-30 & 14.21 & $<$ Detect & 1.99 & 1.23 & 2.92 & 0.14 & 7.53 & $<$ Detect & 1.24 & 0.63 & 20.72 & 36.87 & 0.02 & 6.12 & 1.16 & 3.57 & 0.76 \\
\hline RSM-FEP-34 & 13.69 & $<$ Detect & 1.93 & 1.23 & 2.84 & 0.13 & 7.40 & $<$ Detect & 1.26 & 0.62 & 20.72 & 37.21 & 0.02 & 6.09 & 1.32 & 3.67 & 0.72 \\
\hline RSM-FEP-38 & 13.82 & $<$ Detect & 1.94 & 1.24 & 2.90 & 0.14 & 7.45 & $<$ Detect & 1.16 & 0.64 & 21.06 & 37.90 & 0.02 & 6.17 & 0.99 & 3.62 & 0.78 \\
\hline RSM-FEP-48 & 13.55 & $<$ Detect & 1.99 & 1.17 & 2.85 & 0.12 & 7.50 & $<$ Detect & 1.10 & 0.64 & 21.06 & 38.82 & 0.01 & 5.93 & 1.16 & 3.70 & 0.76 \\
\hline RSM-FEP-54B & 13.52 & $<$ Detect & 2.00 & 1.19 & 2.81 & 0.14 & 7.50 & $<$ Detect & 1.12 & 0.65 & 21.33 & 37.79 & 0.01 & 6.01 & 1.24 & 3.66 & 0.74 \\
\hline RSM-FEP-59 & 14.80 & $<$ Detect & 1.97 & 1.19 & 2.84 & 0.13 & 7.35 & $<$ Detect & 1.24 & 0.62 & 20.18 & 38.13 & 0.01 & 6.17 & 1.47 & 3.67 & 0.63 \\
\hline RSM-FEP-61 & 14.81 & $<$ Detect & 2.00 & 1.20 & 2.77 & 0.14 & 7.55 & $<$ Detect & 1.17 & 0.64 & 18.97 & 38.47 & 0.01 & 6.18 & 1.27 & 3.81 & 0.66 \\
\hline RSM-FEP-63B & 14.97 & $<$ Detect & 2.00 & 1.20 & 2.78 & 0.13 & 7.34 & $<$ Detect & 1.23 & 0.63 & 20.18 & 39.50 & 0.01 & 6.31 & 1.35 & 3.84 & 0.69 \\
\hline RSM-FEP-65 & 14.71 & $<$ Detect & 1.57 & 1.20 & 2.74 & 0.13 & 7.10 & $<$ Detect & 1.28 & 0.61 & 20.66 & 39.73 & 0.01 & 6.41 & 2.22 & 3.78 & 0.62 \\
\hline RSM-FEP-68 & 14.38 & $<$ Detect & 1.93 & 1.19 & 2.66 & 0.13 & 7.15 & $<$ Detect & 1.18 & 0.64 & 20.79 & 39.04 & 0.01 & 6.24 & 2.38 & 3.79 & 0.68 \\
\hline RSM-FEP-72B & 14.31 & $<$ Detect & 1.89 & 1.21 & 2.63 & 0.13 & 6.53 & $<$ Detect & 1.29 & 0.61 & 20.66 & 38.70 & 0.01 & 6.21 & 2.48 & 3.88 & 0.64 \\
\hline RSM-FEP-74 & 14.47 & $<$ Detect & 1.91 & 1.20 & 2.72 & 0.13 & 7.28 & $<$ Detect & 1.15 & 0.64 & 20.45 & 38.59 & 0.01 & 6.26 & 2.41 & 3.86 & 0.67 \\
\hline RSM-FEP-76 & 14.04 & $<$ Detect & 1.89 & 1.23 & 2.55 & 0.13 & 7.05 & $<$ Detect & 1.15 & 0.64 & 19.91 & 39.50 & 0.01 & 6.11 & 2.42 & 3.90 & 0.65 \\
\hline Average & 14.19 & & 1.91 & 1.20 & 2.73 & 0.13 & 7.25 & & 1.18 & 0.62 & 20.54 & 38.49 & 0.01 & 6.15 & 1.78 & 3.70 & 0.70 \\
\hline Target & 13.21 & 0.03 & 1.77 & 1.06 & 2.7 & 0.13 & 7.1 & & 0.78 & 0.71 & 20.03 & 38.06 & 0.03 & 5.58 & 4.37 & 3.55 & 0.71 \\
\hline
\end{tabular}




\subsection{Toxicity Characteristic Leaching Procedure}

A sample of quenched glass, RSM-FEP-16, was sent to Southwest Research Institute for toxicity characteristic leaching procedure (TCLP) analysis, following U.S. Environmental Protection Agency (EPA) Test Method 1311. Table 8.2 gives the results of the analysis and the EPA criterion for meeting landfill disposal requirements. The RSM-FEP-16 sample concentrations were lower than the EPA limit by nearly three orders of magnitude.

Table 8.2. TCLP Sample RSM-FeP-16

\begin{tabular}{cccc}
\hline CAS No. & Analyte & Concentration $(\mu \mathrm{g} / \mathrm{L})$ & EPA Regulator Levels $(\mu \mathrm{g} / \mathrm{L})$ \\
\hline $7440-38-2$ & Arsenic & 10.0 & 5000 \\
$7440-39-3$ & Barium & 10.0 & 100,000 \\
$7440-43-9$ & Cadmium & 5.0 & 1000 \\
$7440-47-3$ & Chromium & 5.0 & 5000 \\
$7439-92-1$ & Lead & 14.7 & 500 \\
$7439-97-6$ & Mercury & 0.2 & 200 \\
$7782-49-2$ & Selenium & 10.0 & 1000 \\
$7440-22-4$ & Silver & 5.0 & 5000 \\
\hline
\end{tabular}

\subsection{Heat Treatment of Glass Using Canister Centerline Cooling Profile}

Select glass samples were heat treated following the LAW canister centerline cooling (CCC) profile from Petkus ${ }^{1}$, but modified for iron-phosphate glass by starting the heating at $1000^{\circ} \mathrm{C}$ rather than $1115^{\circ} \mathrm{C}$ (See Table 8.3 and Figure 8.1). At PNNL, about $30 \mathrm{~g}$ of quenched glass was placed in a Pt-10\%Rh box $\left(2.5 \mathrm{~cm}^{3}\right)$, covered with a lid, and placed in a high temperature furnace at $1000^{\circ} \mathrm{C}$ for $\sim 30$ minutes. It was then cooled by a programmable furnace controller following the CCC schedule shown in Table 8.3. Some of the samples from the CCC heat treatment were characterized by XRD and durability tests (PCT and VHT).

Table 8.3. CCC Schedule For Iron Phosphate Glasses Melted at $\sim 1000^{\circ} \mathrm{C}$

\begin{tabular}{cccc}
\hline Segment & Time $(\mathrm{min})$ & Start Temp $\left({ }^{\circ} \mathrm{C}\right)$ & Rate $\left({ }^{\circ} \mathrm{C} / \mathrm{min}\right)$ \\
\hline 1 & $0-57$ & 1000 & -1.754 \\
2 & $57-179$ & 900 & -0.615 \\
3 & $179-339$ & 825 & -0.312 \\
4 & $339-624$ & 775 & -0.175 \\
5 & $624-1584$ & 725 & -0.13 \\
6 & $1584-3694$ & 600 & -0.095 \\
\hline
\end{tabular}

\footnotetext{
${ }^{1}$ Petkus LL. 2003. “Low Activity Container Centerline Cooling Data.” Memorandum to C.A. Music, dtd. October 16, 2003, CCN: 074181, River Protection Project, Hanford Tank Waste Treatment and Immobilization Plant, Richland, Washington.
} 


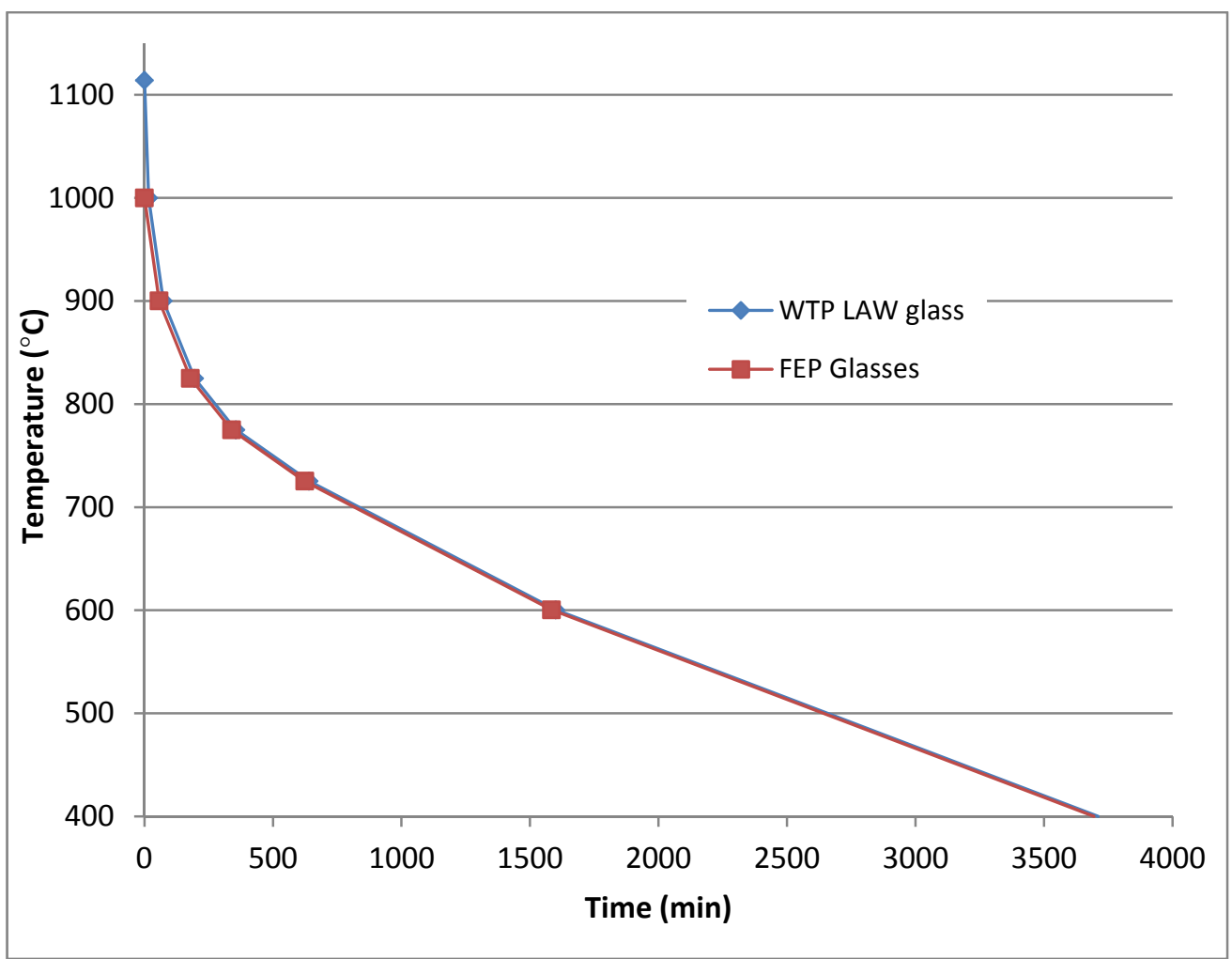

Figure 8.1. Graph of CCC Heat Treatments of Both FEP and LAW Glass

\subsection{Chemical Durability by PCT}

SRNL performed the PCT, in duplicate, on quenched and CCC glass to assess chemical durability using ASTM Procedure C-1285_02, Method A; results are summarized in Table 8.4. Also included in the experimental test matrix was the environmental assessment glass, the ARM glass, and blanks from the sample cleaning batch. Samples were ground, washed, and prepared according to the standard procedure. The resulting solutions were sampled (i.e., filtered and acidified) and analyzed. Normalized release rates were calculated based on target compositions using the average of the leachate concentrations. 
Table 8.4. PCT Test Results

\begin{tabular}{|c|c|c|c|c|c|c|c|c|}
\hline \multirow{2}{*}{ Glass ID } & \multicolumn{8}{|c|}{ NL $(g / L)$} \\
\hline & $\mathrm{Al}$ & B & $\mathrm{Cr}$ & $\mathrm{Fe}$ & $\mathrm{Na}$ & $\mathrm{P}$ & $\mathrm{S}$ & $\mathrm{Si}$ \\
\hline RSM-FEP-10ccc & 0.87 & $<$ Detect & $<$ Detect & $<$ Detect & 1.66 & 0.68 & 1.01 & 1.00 \\
\hline RSN-FEP-12 & 0.47 & $<$ Detect & $<$ Detect & $<$ Detect & 1.42 & 0.68 & $<$ Detect & 0.57 \\
\hline RSM-FEP-18ccc & 1.14 & $<$ Detect & $<$ Detect & $<$ Detect & 1.98 & 0.93 & $<$ Detect & 1.08 \\
\hline RSM-FEP-24 & 0.68 & $<$ Detect & $<$ Detect & $<$ Detect & 1.80 & 0.91 & $<$ Detect & 0.68 \\
\hline RSM-FEP-24cCC & 1.39 & $<$ Detect & $<$ Detect & $<$ Detect & 2.29 & 1.15 & $<$ Detect & 1.09 \\
\hline RSM-FEP-30 & 0.68 & $<$ Detect & $<$ Detect & $<$ Detect & 1.83 & 0.93 & $<$ Detect & 0.67 \\
\hline RSM-FEP-34ccc & 1.51 & $<$ Detect & $<$ Detect & $<$ Detect & 2.56 & 1.30 & $<$ Detect & 1.05 \\
\hline RSM-FEP-38 & 0.78 & $<$ Detect & $<$ Detect & $<$ Detect & 2.04 & 1.04 & $<$ Detect & 0.73 \\
\hline RSM-FEP-38сcс & 1.55 & $<$ Detect & $<$ Detect & 0.01 & 2.64 & 1.33 & $<$ Detect & 1.13 \\
\hline RSM-FEP-48ccc & 1.30 & $<$ Detect & $<$ Detect & $<$ Detect & 2.02 & 1.02 & $<$ Detect & 1.24 \\
\hline RSM-FEP-54B & 0.63 & $<$ Detect & $<$ Detect & $<$ Detect & 1.67 & 0.86 & $<$ Detect & 0.60 \\
\hline RSM-FEP-59 & 0.64 & $<$ Detect & $<$ Detect & $<$ Detect & 1.54 & 0.76 & $<$ Detect & 0.51 \\
\hline RSM-FEP-59ccс & 1.44 & $<$ Detect & $<$ Detect & $<$ Detect & 2.35 & 1.16 & $<$ Detect & 1.19 \\
\hline RSM-FEP-61 & 0.64 & $<$ Detect & $<$ Detect & $<$ Detect & 1.59 & 0.76 & $<$ Detect & 0.59 \\
\hline RSM-FEP-61CCC & 1.32 & $<$ Detect & $<$ Detect & $<$ Detect & 2.13 & 1.03 & $<$ Detect & 1.22 \\
\hline RSM-FEP-63Всcс & 1.33 & $<$ Detect & $<$ Detect & $<$ Detect & 2.26 & 1.10 & $<$ Detect & 1.10 \\
\hline RSM-FEP-65 & 0.52 & $<$ Detect & $<$ Detect & $<$ Detect & 1.51 & 0.77 & $<$ Detect & 0.55 \\
\hline RSM-FEP-65ccc & 0.85 & $<$ Detect & $<$ Detect & $<$ Detect & 1.61 & 0.63 & 1.05 & 1.08 \\
\hline RSM-FEP-68 & 0.48 & $<$ Detect & $<$ Detect & $<$ Detect & 1.39 & 0.71 & $<$ Detect & 0.54 \\
\hline RSM-FEP-68ccс & 0.85 & $<$ Detect & $<$ Detect & $<$ Detect & 1.64 & 0.66 & 1.12 & 1.10 \\
\hline RSM-FEP-72BсcC & 0.83 & $<$ Detect & $<$ Detect & $<$ Detect & 1.65 & 0.68 & 1.23 & 1.05 \\
\hline RSM-FEP-74 & 0.49 & $<$ Detect & $<$ Detect & $<$ Detect & 1.31 & 0.64 & $<$ Detect & 0.46 \\
\hline RSM-FEP-74ccc & 0.89 & $<$ Detect & $<$ Detect & $<$ Detect & 1.62 & 0.65 & $<$ Detect & 1.07 \\
\hline RSM-FEP-76сcс & 0.82 & $<$ Detect & $<$ Detect & $<$ Detect & 1.56 & 0.62 & 1.10 & 1.04 \\
\hline
\end{tabular}

\subsection{Iron Redox Analysis}

SRNL determined the Iron redox of the glass using a colorimetric technique with UV-Vis spectroscopy ${ }^{2}$ according to procedure ITS-0042. ${ }^{3}$ Crushed glass samples were dissolved in a sulfuric-hydrofluoric acid mixture, containing ammonium metavanadate. Boric acid was added to the mixture to destroy any iron-fluoride complexes. The solution was added to a buffered ferrozine reagent and the absorbance at $562 \mathrm{~nm}$ was measured in order to determine $\mathrm{Fe}^{2+}$ content. A second absorbance measurement was conducted at $562 \mathrm{~nm}$ after ascorbic acid had been added, which determined the total iron content. Table 8.5 displays the results of the analyses as well as visual observations.

\footnotetext{
2 Thermo Spectronic Genesys 6

3 "Determining $\mathrm{Fe}^{2+} / \mathrm{Fe}^{3+}$ and $\mathrm{Fe}^{2+} / \mathrm{Fe}$ (total) Using UV-Vis Spectrometry," ITS-0042, Savannah River National Laboratory, Aiken, SC, latest revision.
} 
Table 8.5. Iron Redox Analyses

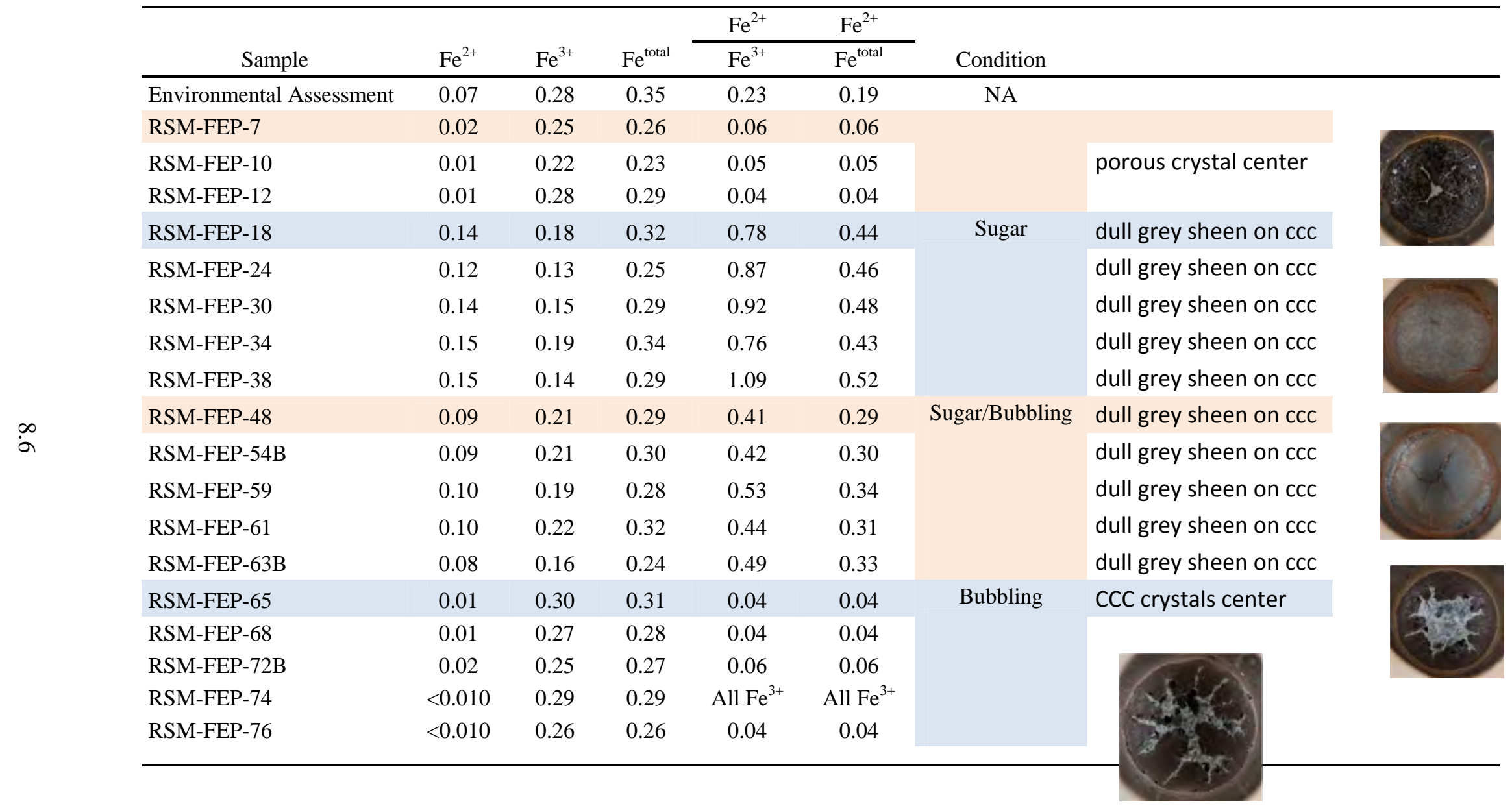




\subsection{Glass Density}

SRNL measured the densities of the glass samples given in Table 8.6 via helium pycnometry. ${ }^{1}$ The average glass density was 2.77 .

Table 8.6. Glass Sample Densities

\begin{tabular}{ll}
\hline \multicolumn{1}{c}{ Sample } & \multicolumn{2}{c}{ Density (g/cc) } \\
\hline NIST & 2.54 \\
RSM-FEP-7 & 2.80 \\
RSM-FEP-10 & 2.78 \\
RSM-FEP-12 & 2.77 \\
RSM-FEP-18 & 2.81 \\
RSM-FEP-24 & 2.78 \\
RSM-FEP-30 & 2.74 \\
RSM-FEP-34 & 2.82 \\
RSM-FEP-38 & 2.79 \\
RSM-FEP-48 & 2.80 \\
RSM-FEP-54B & 2.76 \\
RSM-FEP-59 & 2.79 \\
RSM-FEP-61 & 2.80 \\
RSM-FEP-63B & 2.75 \\
RSM-FEP-65 & 2.74 \\
RSM-FEP-68 & 2.77 \\
RSM-FEP-72B & 2.75 \\
RSM-FEP-74 & 2.74 \\
RSM-FEP-76 & 2.75 \\
\hline
\end{tabular}

\subsection{Crystallinity by XRD}

XRD data were collected at SRNL and at PNNL, both on a Bruker D8 X-ray Diffractometer by step scanning over the range of $5-70^{\circ} 2 \Theta$ with a step size of $0.02^{\circ}$ and a dwell time of $1 \mathrm{~s}$ at SRNL and a step size of $0.015^{\circ}$ and a $0.3 \mathrm{~s}$ dwell at each step at PNNL. The XRD scans with matching crystal patterns are presented in Appendix B. Data at PNNL were analyzed with Jade 6.0 Software (from MDI, Inc.) for phase identification.

All samples, whether quenched or CCC, had eskolaite as a crystalline material. For quenched samples, eskolaite was the major crystalline phase; however, it was present as a minor volume fraction in the glass. In the CCC heat-treated samples, eskolaite appeared as a minor crystalline phase. Sodium iron phosphate was identified as the major phase with several other crystalline phases present; however, the identification of these minor phases is questionable.

\footnotetext{
${ }^{1}$ Quantachrome Multipycnometer.
} 


\subsection{Chemical Durability by VHT}

Samples from both quenched and CCC heat-treated glasses were selected for durability testing by VHT; results are listed in Table 8.7. Photos, SEM micrographs, and measured data are presented in Appendix A.

In the VHT, monolithic samples were exposed to water vapor at $200^{\circ} \mathrm{C}$ in sealed $22 \mathrm{~mL}$ stainless steel vessels (Type 304L). A diamond-impregnated saw was used to produce samples, $10 \times 10 \times 1.5 \mathrm{~mm}$ $(0.4 \times 0.4 \times 0.06 \mathrm{in}$.), from glass or CCC pieces. The cut samples were polished to 600 -grit surface finishes with silicon carbide paper. In the vessels, samples were suspended on a Pt wire above $0.20 \mathrm{~g}$ of deionized water and held at $200^{\circ} \mathrm{C}$ for 7 days. Following the test, the specimens were sectioned through the center of the sample for optical microscopy coupled with image analysis evaluation. Image analysis measurements of the average remaining glass thickness at ten locations were used to calculate corrosion. The average rate of corrosion was calculated as $r_{a}=m / t$, where $m$ is the mass of the glass altered, and $t$ is the corrosion time. Some samples were selected for SEM analysis, especially if the alteration layer from glass corrosion was thin or difficult to observe using optical microscopy.

Table 8.7. Results of RSM Sample Testing by VHT

\begin{tabular}{lcc}
\hline $\begin{array}{c}\text { Sample } \\
\text { Identification }\end{array}$ & $\begin{array}{c}\text { Quenched or } \\
\text { CCC }\end{array}$ & $\begin{array}{c}\text { VHT Result } \\
\left(\mathrm{g} / \mathrm{m}^{2}\right)\end{array}$ \\
\hline RSM-FEP-6 & Quenched & 18 \\
RSM-FEP-6(1) & CCC & 1021 \\
RSM-FEP-6(2) & CCC & 285 \\
RSM-FEP-6(3) & CCC & 335 \\
RSM-FEP-16 & Quenched & 3 \\
RSM-FEP-31 & Quenched & $<15$ \\
RSM-FEP-54A & Quenched & 16 \\
RSM-FEP-54A & CCC & 1034 \\
RSM-FEP-63A & CCC & 204 \\
RSM-FEP-70 & CCC & 860 \\
\hline
\end{tabular}

The CCC heat treatment of RSM-FEP-6 glass had distinct layers, the top half of the sample was light and the bottom was dark colored. Samples were cut from the material so that a specimen from each area was obtained. Also a sample at the boundary of light and dark region was obtained so that one side of the sample was light and the other side was dark (photos are provided in Appendix A). These three samples were tested by VHT to determine if there was a difference between the two phases. The results in Table 8.7 show that the lighter phase [RSM-FEP-6 (1)] was less durable than the dark phase.

The quenched VHT samples had very little corrosion present following the 7-day test at $200^{\circ} \mathrm{C}$. The CCC heat-treated samples had measured corrosion from 200 to just over $1000 \mathrm{~g} / \mathrm{m}^{2}$. It is uncertain why there is such a wide difference between samples. Further investigation is needed to understand this phenomenon. VHT may not be a good measure of durability for this waste form because of the change from amorphous to crystalline material during canister cooling. The effect of cooling on corrosion in this waste form warrants further investigation. 


\subsection{Material Balance}

A material balance of selected volatile and non-volatile species was performed along with decontamination factors based on glass produced and material collected in the scrub tank. The testing envelope was made using the glass analysis in Table 8.1, the simulant recipe listed in Table 10.2 for the feed, and scrubber analysis in Table 7.5 for the overhead losses. The average rates of some key components are shown in Figure 9.1. As expected, non-volatile components remained in the glass phase. $\mathrm{S}$ data was converted to elemental $\mathrm{S}$ for the purpose of comparison. Discrepancies in the glass and offgas totals as compared to the feed for the non-volatile species may be related to either the scrubbing efficiency or the problems caused by the feeding disruptions. The additional losses that appear for the Re may be due to inefficiencies of the offgas scrubbing equipment, which uses highly acidic condensate for scrubbing. The data shows significant losses of $\mathrm{S}$ from the melter but within the requirements for the low-level waste melter. The scrub data along with the feed rate and concentration data also indicates that air bubbling likely increases the losses of $\mathrm{S}$ from the melter. The glass composition data indicates the sugar may increase losses of $\mathrm{S}$ from the melter, probably through reduction of $\mathrm{SO}_{4}$ to $\mathrm{SO}_{3}$ or $\mathrm{SO}_{2}$.

The decontamination factors for the test, defined as the component in the feed divided by the component collected in the offgas scrubber for a unit of time within a segment, are show in Table 9.1.

Table 9.1. Decontamination Factors

\begin{tabular}{|c|c|c|c|c|c|}
\hline \multicolumn{3}{|c|}{ Decontamination Factors } & \multirow{2}{*}{$\begin{array}{c}\begin{array}{c}\text { Based on } \\
\text { Feed }\end{array} \\
4\end{array}$} & \multirow[b]{2}{*}{5} & \multirow[b]{2}{*}{ Average } \\
\hline Segment \# & 2 & 3 & & & \\
\hline $\mathrm{Al}$ & 437 & 365 & 731 & 515 & 512 \\
\hline B & 12 & 54 & 89 & 42 & 49 \\
\hline $\mathrm{Bi}$ & 627 & 2766 & 13,632 & 640 & 4417 \\
\hline $\mathrm{Ca}^{(\mathrm{a})}$ & 182 & 209 & 566 & 306 & 316 \\
\hline $\mathrm{Cr}$ & 914 & 2196 & 4342 & 1784 & 2309 \\
\hline Cs & 121 & 159 & 127 & 5 & 103 \\
\hline $\mathrm{F}$ & 4 & 9 & 6 & 3 & 5 \\
\hline $\mathrm{Fe}$ & 652 & 1447 & 1738 & 769 & 1152 \\
\hline I & 28 & 7 & 8 & 7 & 12 \\
\hline $\mathrm{K}$ & 154 & 203 & 193 & 150 & 175 \\
\hline $\mathrm{La}$ & 779 & 484 & 799 & 768 & 708 \\
\hline $\mathrm{Na}$ & 70 & 116 & 112 & 122 & 105 \\
\hline $\mathrm{PO} 4$ & 428 & 662 & 976 & 581 & 662 \\
\hline $\operatorname{Re}$ & 7.6 & 8.4 & 6.4 & 5.2 & 7 \\
\hline S & 5.9 & 2.1 & 2.8 & 2.4 & 3 \\
\hline $\mathrm{Si}^{(\mathrm{a})}$ & 1119 & 1571 & 15,229 & 680 & 4650 \\
\hline $\mathrm{Zn}$ & 15 & 13 & 29 & 18 & 19 \\
\hline $\mathrm{Zr}$ & 1204 & 893 & NA & 237 & 778 \\
\hline
\end{tabular}

(a) Based on glass composition 


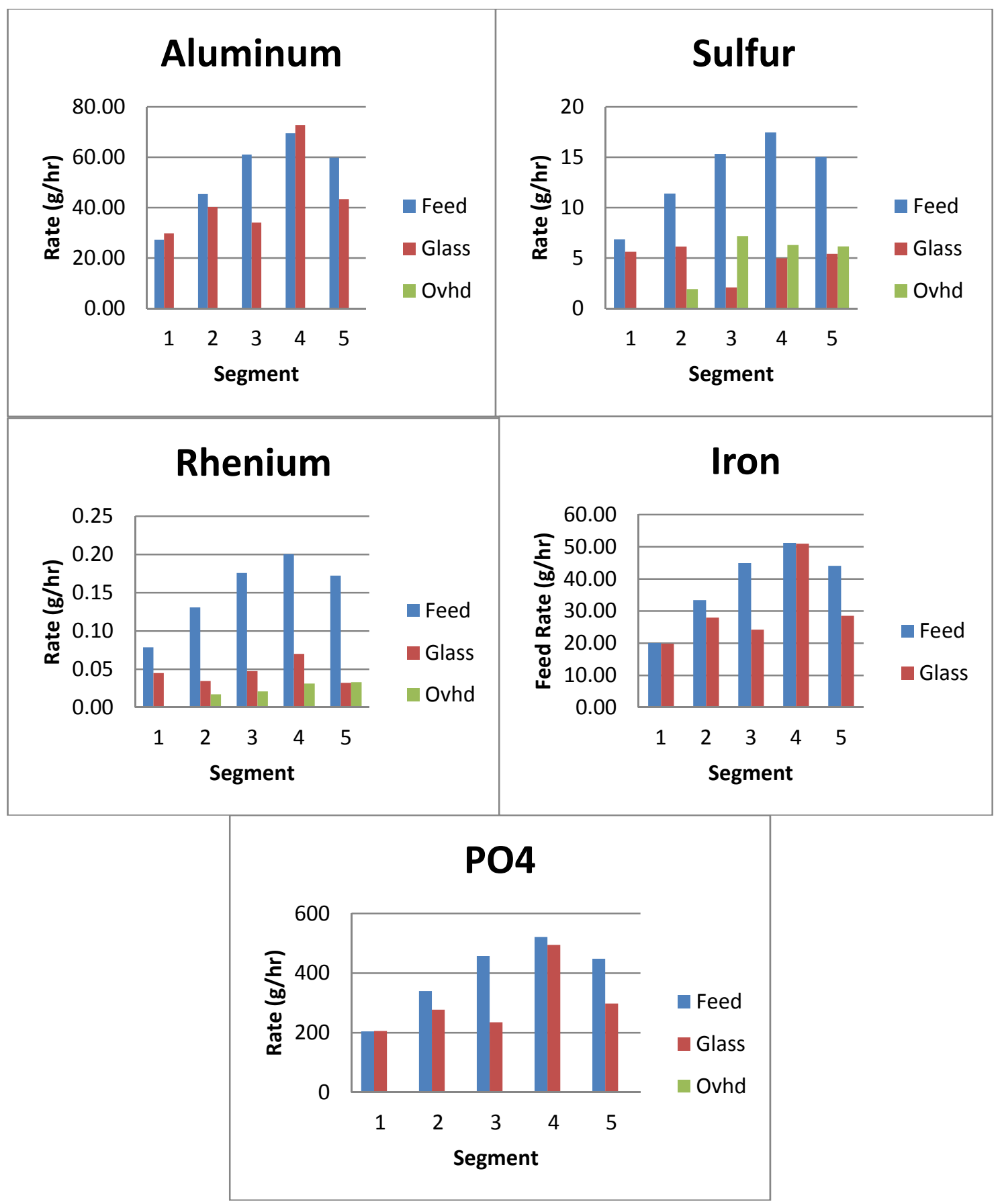

Figure 9.1. Rates of Components of Interest 


\subsection{Surrogate Waste and Feed Mixture}

The surrogate waste processed during the RSM test was representative of AZ102 tank waste. The equivalent oxide feed formulation to be processed was composed of $\sim 26 \%$ waste oxides and $\sim 74 \%$ glass formers composed of $\mathrm{Al}, \mathrm{Cr}, \mathrm{P}, \mathrm{Si}, \mathrm{Bi}, \mathrm{Ca}, \mathrm{Fe}, \mathrm{La}, \mathrm{Zn}$, and $\mathrm{Zr}$ oxides. Table 10.1 summarizes the AZ-102 equivalent waste oxide composition. Table 10.1 also shows the relative proportions of the glass formers used and the resultant target glass composition to be prepared during melter testing. The raw materials used for the feed preparation are shown in Table 10.2 and Table 10.3. The composition of the feed mixture was based on measured feed properties. Sampling of the melter feed stream during of the test provided for post-test analytical validation of batch compositions.

Table 10.1. MS26AZ102F-2 Glass Composition

\begin{tabular}{|c|c|c|c|c|}
\hline \multicolumn{2}{|c|}{ MS26AZ102F-2 } & & & \\
\hline Oxide (wt\%) & Hanford LAW (AZ-102) & 26 wt\% Hanford LAW (AZ-102) & $74 \mathrm{wt} \%$ additives & Target Composition \\
\hline $\mathrm{Al} 2 \mathrm{O} 3$ & 0.27 & 0.07 & 13.14 & 13.21 \\
\hline $\mathrm{B} 2 \mathrm{O} 3$ & 0.10 & 0.03 & 0.00 & 0.03 \\
\hline $\mathrm{Cl}$ & 0.14 & 0.04 & 0.00 & 0.04 \\
\hline $\mathrm{Cr} 2 \mathrm{O} 3$ & 0.81 & 0.21 & 2.49 & 2.70 \\
\hline $\mathrm{Cs} 2 \mathrm{O}$ & 0.50 & 0.13 & 0.00 & 0.13 \\
\hline $\mathrm{F}$ & 0.60 & 0.16 & 0.00 & 0.16 \\
\hline $\mathrm{K} 2 \mathrm{O}$ & 3.01 & 0.78 & 0.00 & 0.78 \\
\hline $\mathrm{Na2O}$ & 77.04 & 20.03 & 0.00 & 20.03 \\
\hline $\mathrm{P} 2 \mathrm{O5}$ & 0.22 & 0.06 & 38.00 & 38.06 \\
\hline $\mathrm{Re} 2 \mathrm{O} 7$ & 0.10 & 0.03 & 0.00 & 0.03 \\
\hline $\mathrm{SiO} 2$ & 0.43 & 0.11 & 5.47 & 5.58 \\
\hline $\mathrm{SO} 3$ & 16.79 & 4.37 & 0.00 & 4.37 \\
\hline Total & 100.01 & 26.00 & & \\
\hline $\mathrm{Bi} 2 \mathrm{O} 3$ & & & \begin{tabular}{|l|}
1.77 \\
\end{tabular} & 1.77 \\
\hline $\mathrm{CaO}$ & & & 1.06 & 1.06 \\
\hline Fe2O3 & & & 7.10 & 7.10 \\
\hline La2O3 & & & 0.71 & 0.71 \\
\hline $\mathrm{ZnO}$ & & & 3.55 & 3.55 \\
\hline $\mathrm{ZrO} 2$ & & & 0.71 & 0.71 \\
\hline & & & & \\
\hline Total & & & 74.00 & 100.00 \\
\hline
\end{tabular}


Table 10.2. Simulant Recipe

LAW AZ-102 Simulant Recipe at 7 Molar Sodium (Hansen, 2010).

Target volume of simulant: $\quad 2 \mathrm{~L}$

Expected simulant density: $1.320 \mathrm{~g} / \mathrm{ml}$

\begin{tabular}{|c|c|c|c|c|c|c|c|c|c|c|c|c|c|c|c|c|c|c|}
\hline \multirow{2}{*}{ 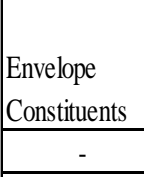 } & \multirow{2}{*}{$\begin{array}{c}\text { Mole } \\
\text { wt } \\
- \\
\end{array}$} & \multicolumn{2}{|c|}{$\begin{array}{c}1.3 \mathrm{M} \mathrm{Na} \\
\text { Simulant target }\end{array}$} & \multicolumn{2}{|c|}{$\begin{array}{c}7 \mathrm{M} \text { Na Simulant } \\
\text { target }\end{array}$} & \multicolumn{2}{|c|}{$\begin{array}{c}7 \text { M Na Simulant } \\
\text { calculated from } \\
\text { ingredients }\end{array}$} & \multirow{2}{*}{\begin{tabular}{|c|}
$\begin{array}{c}\text { Glass } \\
\text { Oxide }\end{array}$ \\
- \\
\end{tabular}} & \multirow[t]{2}{*}{ Mole wt } & \multicolumn{2}{|c|}{$\begin{array}{c}\text { TRR-PLT-073 } \\
\text { Target Glass } \\
\text { Oxide } \\
\end{array}$} & \multicolumn{2}{|c|}{$\begin{array}{c}\text { Glass Oxide } \\
\text { calculated from } \\
\text { ingredients }\end{array}$} & \multirow{2}{*}{\begin{tabular}{|l}
\multicolumn{1}{|c}{ Source in Simulant } \\
DI water \\
\end{tabular}} & \multirow{2}{*}{\begin{tabular}{|c|}
$\begin{array}{c}\text { Order for } \\
\text { Addition }\end{array}$ \\
1 \\
\end{tabular}} & \multirow{2}{*}{\begin{tabular}{|c|}
$\begin{array}{c}\text { Formula } \\
\text { Weight }\end{array}$ \\
18 \\
\end{tabular}} & \multirow{2}{*}{$\begin{array}{c}\text { Assay* } \\
1 \\
\end{array}$} & \multirow{2}{*}{$\begin{array}{c}\begin{array}{c}\text { Target } \\
\text { Weight (g) }\end{array} \\
800.000\end{array}$} \\
\hline & & $\mathrm{mg} / \mathrm{L}$ & $\mathrm{M}$ & $\mathrm{mg} / \mathrm{L}$ & $\mathrm{M}$ & $\mathrm{mg} / \mathrm{L}$ & $\mathrm{M}$ & & & $\mathrm{mg} / \mathrm{L}$ & $\mathrm{wt} \%$ & $\mathrm{mg} / \mathrm{L}$ & $\mathrm{wt} \%$ & & & & & \\
\hline $\mathrm{Al}$ & 26.98 & 75.8 & 0.003 & 408 & 0.016 & 408 & 0.015 & $\mathrm{Al}_{2} \mathrm{O}_{3}$ & 101.96 & 143 & 0.27 & 772 & $0.27 \%$ & $\mathrm{Al}(\mathrm{NO}) 3 * 9 \mathrm{H} 2 \mathrm{O}$ & 8 & 375.14 & 0.980 & 11.586 \\
\hline B & 10.81 & 15.6 & 0.001 & 84 & 0.005 & 84 & 0.008 & $\mathrm{~B}_{2} \mathrm{O}_{3}$ & 69.62 & 50 & 0.10 & 272 & $0.10 \%$ & H3ВО3 & 5 & 61.83 & 1.005 & 0.961 \\
\hline $\mathrm{Cr}$ & 52 & 288.8 & 0.006 & 1,555 & 0.032 & 1,556 & 0.030 & $\mathrm{Cr}_{2} \mathrm{O}_{3}$ & 151.99 & 422 & 0.81 & 2,274 & $0.81 \%$ & $\mathrm{Na} 2 \mathrm{CrO} 4 * 4 \mathrm{H} 2 \mathrm{O}$ & 3 & 234.04 & 0.990 & 14.146 \\
\hline Cs Spike \$ & 132.91 & 247 & 0.002 & 1,330 & 0.011 & 1,331 & 0.010 & $\mathrm{Cs}_{2} \mathrm{O}$ & 281.81 & 262 & 0.50 & 1,411 & $0.50 \%$ & $\mathrm{CsNO3}$ & 4 & 194.91 & 0.995 & 3.922 \\
\hline $\mathrm{K}$ & 39.1 & 1306.2 & 0.033 & 7,033 & 0.178 & 7,037 & 0.180 & $\mathrm{~K}_{2} \mathrm{O}$ & 94.2 & 1,573 & 3.01 & 8,477 & $3.01 \%$ & $\mathrm{KOH}$ & 7 & 56.10 & 0.887 & 22.766 \\
\hline $\mathrm{Na}$ & 22.99 & 29887 & 1.300 & 160,930 & 7.000 & 161,006 & 7.003 & $\mathrm{Na}_{2} \mathrm{O}$ & 61.98 & 40,287 & 76.96 & 217,032 & $76.96 \%$ & $\mathrm{NaOH}, 50 \%$ sol. d=1.53 & 6 & 40.00 & 0.502 & 61.148 \\
\hline $\mathrm{Si}$ & 28.09 & 105.4 & 0.004 & 568 & 0.022 & 568 & 0.020 & $\mathrm{SiO}_{2}$ & 60.08 & 225 & 0.43 & 1,215 & $0.43 \%$ & $\mathrm{SiO} 2$ & 16 & 60.09 & 0.995 & 2.442 \\
\hline $\mathrm{Cl}$ & 35.45 & 73.6 & 0.002 & 396 & 0.011 & 396 & 0.011 & $\mathrm{Cl}$ & 35.45 & 74 & 0.14 & 396 & $0.14 \%$ & $\mathrm{NaCl}$ & 10 & 58.45 & 1.000 & 1.307 \\
\hline $\mathrm{F}$ & 19 & 311.4 & 0.016 & 1,677 & 0.086 & 1,677 & 0.088 & $\mathrm{~F}$ & 19 & 311 & 0.59 & 1,677 & $0.59 \%$ & $\mathrm{NaF}$ & 11 & 42.00 & 0.998 & 7.430 \\
\hline I spike & 126.9 & --- & --- & 282 & 0.00222 & 282 & 0.002 & I & 126.9 & 52 & 0.10 & 282 & $0.10 \%$ & $\mathrm{NaI}$ & 17 & 149.89 & 1.000 & 0.665 \\
\hline $\mathrm{PO} 4$ & 94.97 & 152.4 & 0.002 & 821 & 0.011 & 821 & 0.009 & $\mathrm{P}_{2} \mathrm{O}_{5}$ & 141.94 & 114 & 0.22 & 614 & $0.22 \%$ & $\mathrm{Na} 3 \mathrm{PO}_{4} * 12 \mathrm{H} 2 \mathrm{O}$ & 9 & 380.12 & 1.000 & 6.572 \\
\hline $\mathrm{SO} 4$ & 96.06 & 10535 & 0.110 & 56,727 & 0.592 & 56,744 & 0.591 & $\mathrm{SO}_{3}$ & 80.06 & 8,780 & 16.77 & 47,293 & $16.77 \%$ & $\mathrm{Na} 2 \mathrm{SO} 4$ & 12 & 142.06 & 0.992 & 169.188 \\
\hline Re Spike \$ & 186.21 & 40.3 & 0.0002 & 217 & 0.0011 & 217 & 0.0012 & $\mathrm{Re}_{2} \mathrm{O}_{7}$ & 484.41 & 52 & 0.10 & 282 & $0.10 \%$ & $\mathrm{NaReO4}$ & 17 & 273.19 & 1.000 & 0.637 \\
\hline NO2 & \begin{tabular}{|l|}
46.01 \\
\end{tabular} & 14572 & 0.317 & 78,465 & 1.707 & 78,503 & 1.706 & - & & - & - & & & NaNO2 & 13 & 69.00 & 0.997 & 236.165 \\
\hline NO3 & 62 & \begin{tabular}{|l|}
4820 \\
\end{tabular} & 0.078 & 25,954 & 0.420 & 25,965 & 0.419 & - & & - & - & & & NaNO3 & 14 & 84.99 & 0.999 & 71.257 \\
\hline $\mathrm{CO} 3$ & 60.01 & 16471 & 0.274 & 88,690 & 1.475 & 88,739 & 1.479 & - & & - & - & & & $\mathrm{Na} 2 \mathrm{CO} 3$ & 15 & 105.99 & 1.000 & 313.461 \\
\hline Org. Carbon & 12.01 & 374.8 & 0.031 & 2,018 & 0.167 & - & - & - & & - & - & & & - & - & - & - & \\
\hline Oxalate & 88.02 & 1383 & 0.016 & 7,447 & 0.086 & 7,451 & 0.085 & - & & - & - & & & Sodium Oxalate ( $\mathrm{Na} 2 \mathrm{C} 2 \mathrm{O} 4$ & 2 & 134.00 & 0.990 & 22.916 \\
\hline- & & - & - & & & & & - & & - & - & & & remaining DI water & last & 18 & 1 & 893.714 \\
\hline- & & - & - & & & & & SUM & & 52,347 & 100.00 & 281,995 & $100.00 \%$ & \multicolumn{4}{|l|}{ Total simulant wt. } & $2,640.283$ \\
\hline Notes: & & & & & & & & & & & & & & Total DI water & & & & $1,693.714$ \\
\hline \multicolumn{2}{|c|}{ 1. "-" Empty data field. } & & & & & & & & & & & & & \multicolumn{2}{|c|}{ Calculated simulant density, g/L } & & & 1.320 \\
\hline \multicolumn{8}{|c|}{ 2. Assay refers to the purity of the raw material as specified by the vendor. } & & & & & & & \multicolumn{4}{|c|}{ Measured simulant density, g/L (NOAH 15 November 2010} & 1.32 \\
\hline \multicolumn{13}{|c|}{ 3. Cs, I, and Re are spiked at concentrations to provide $0.5 \mathrm{wt} \%$ Cs2O, $0.1 \mathrm{wt} \% \mathrm{I}$, and $0.1 \mathrm{wt} \%$ Re2O7 in simulant oxide composition. } & & & \multicolumn{4}{|c|}{ [CCIM OGSE sample RFA 28jan09.xls]srnl rfa } \\
\hline
\end{tabular}


Table 10.3. Glass Forming Chemicals

\begin{tabular}{|c|c|c|c|c|c|c|c|c|c|c|c|c|c|}
\hline AZ-102 simulant Na molarity & & $\mathrm{M}$ & & & & & Oxide & basis & & & Elemen & tal basis & \\
\hline GFCs & Ingredient & mole wt & $\mathrm{g} / \mathrm{L}$ simula & total kg & assay & oxide & mole wt & $\mathrm{gm} / \mathrm{L}$ & wt $\%$ & element & mole wt & $\mathrm{g} / \mathrm{L}$ & wt\% \\
\hline Chromium oxide (ACROS 19208-500) & $\mathrm{Cr} 2 \mathrm{O} 3$ & 152 & 27.241 & 23.496 & 0.990 & $\mathrm{Cr} 2 \mathrm{O} 3$ & 152 & 26.969 & 3.41 & $\mathrm{Cr}$ & 52 & 18.452 & 2.33 \\
\hline Silica oxide & $\mathrm{SiO} 2$ & 60.09 & 58.348 & 50.326 & 1.000 & $\mathrm{SiO} 2$ & 60.09 & 58.348 & 7.38 & $\mathrm{Si}$ & 28.09 & 27.276 & 3.45 \\
\hline Bismuth hydroxide & $\mathrm{H} 3 \mathrm{BiO} 3$ & 260 & 21.394 & 18.453 & 0.990 & $\mathrm{Bi} 2 \mathrm{O} 3$ & 466 & 18.981 & 2.40 & $\mathrm{Bi}$ & 209 & 17.026 & 2.15 \\
\hline Calcium phosphate & $\mathrm{HCaPO} 4$ & 183.02 & 28.344 & 24.447 & 0.980 & $\mathrm{CaO}$ & 56.08 & 8.511 & 1.08 & $\mathrm{Ca}$ & 40.08 & 6.083 & 0.77 \\
\hline Iron oxide (Prince 5001) & $\mathrm{Fe} 2 \mathrm{O} 3$ & 159.7 & 79.275 & 68.376 & 0.990 & $\mathrm{Fe} 2 \mathrm{O} 3$ & 159.7 & 78.482 & 9.93 & $\mathrm{Fe}$ & 55.85 & 54.893 & 6.95 \\
\hline Lanthanum oxide & La2O3 & 325.8 & 7.697 & 6.639 & 0.999 & $\mathrm{La2O} 3$ & 325.8 & 7.689 & 0.97 & La & 138.9 & 6.556 & 0.83 \\
\hline Zinc oxide & $\mathrm{ZnO}$ & 81.39 & 38.526 & 33.229 & 0.998 & $\mathrm{ZnO}$ & 81.39 & 38.449 & 4.87 & $\mathrm{Zn}$ & 65.39 & 30.890 & 3.91 \\
\hline Zirconium oxide & $\mathrm{ZrO} 2$ & 123.22 & 7.690 & 6.633 & 1.000 & ZrO2 & 123.22 & 7.690 & 0.97 & $\mathrm{Zr}$ & 91.22 & 5.693 & 0.72 \\
\hline Aluminum hydroxide to replace AIPO4 & $\mathrm{Al}(\mathrm{OH}) 3$ & 77.98 & 67.722 & 58.412 & 0.995 & $\mathrm{Al} 2 \mathrm{O} 3$ & 101.96 & 138.785 & 17.56 & Al & 26.98 & 73.449 & 9.29 \\
\hline total aluminum metaphosphate & $\mathrm{Al}(\mathrm{PO}) 3$ & 263.89 & 503.457 & 434.242 & 0.974 & P2O5 & 141.94 & 406.406 & 51.42 & $\mathrm{P} 2 \mathrm{O5}$ & 141.94 & 406.406 & 51.42 \\
\hline total simulant, L & 862. & & & & & & sum & 790.309 & 100.00 & & sum & 646.724 & 81.832 \\
\hline
\end{tabular}

[CCIM OGSE sample RFA 28jan09.xls]srnl rfa 



\subsection{Quality Assurance}

All work was performed in accordance with best laboratory practices (NQA-1 Subpart 4.2-based) as indicated in work flows and subject areas of the PNNL HDI standards-based management system in effect at the time the work was conducted. 



\subsection{Conclusions}

Overall, the processing of iron phosphate glass was similar to borosilicate glass, although the melter was operated at a lower average temperature with higher levels of sulfur. The glass production rates were similar to borosilicate glass when sugar and/or bubbling was used. The product glass quality met all low-level waste criteria with and without sugar additions, although there were significant crystals in the centerline cool samples. The corrosion of melter components was acceptable and losses to the melter exhaust were typical of other waste glasses. As expected, the crude bubbler system resulted in increased particulate losses to the exhaust system and the condensate was very acidic. Detailed conclusions are listed below:

- Glass processing rates for iron phosphate glass with $1030^{\circ} \mathrm{C}$ were demonstrated to be 0.31 to $1 \mathrm{~kg} / \mathrm{h}$ (411 to $1330 \mathrm{~kg} / \mathrm{m} 2 /$ day).

- Glass with $4.7 \mathrm{wt} \% \mathrm{SO}_{3}$ can be processed with average process losses of $30 \mathrm{wt} \%$. Higher losses are expected with air bubbling and sugar addition.

- Corrosion of Inconel ${ }^{\mathrm{TM}} 693$ electrodes and Inconel ${ }^{\mathrm{TM}} 690$ pour spout were minimal.

- Glass durability values acceptable with PCT release values less than $3 \mathrm{~g} / \mathrm{L}$ for NA and below detection for $\mathrm{Cr}$ and $\mathrm{B}$. This includes glass cooled at simulated LAW containers centerline cooling rate.

- Durability measurements by VHT were also acceptable with the values less than $1100 \mathrm{~g} / \mathrm{m}^{2}$ for centerlined cooled samples and less than $20 \mathrm{~g} / \mathrm{m}^{2}$ for quenched samples. 



\subsection{References}

ASTM. 1994. Standard Test Methods for Determining Chemical Durability of Nuclear Waste Glasses: The Product Consistency Test (PCT), ASTM C1285-94.

Goles RW and AJ Schmidt. 1992. Evaluation of Liquid-Fed Ceramic Melter Off-Gas System Technologies for the Hanford Waste Vitrification Plant. PNL-8109, Pacific Northwest Laboratory, Richland, WA. 

Appendix A

\section{VHT Results}





\section{Appendix A}

\section{VHT Results}

Photos, micrographs and image analysis measurements

RSM-FEP-6 Quenched VHT Sample (post-test)

\begin{tabular}{|l|r|}
\hline Sample & RSM-FeP-6 \\
\hline Magnification & $20 X$ \\
\hline Date & 7.1 .11 \\
\hline & \\
\hline line 1 & 1.4851251 \\
\hline line 2 & 1.5514464 \\
\hline line 3 & 1.5467092 \\
\hline line 4 & 1.541972 \\
\hline line 5 & 1.541972 \\
\hline line 6 & 1.5301289 \\
\hline line 7 & 1.5159171 \\
\hline line 8 & 1.4756506 \\
\hline line 9 & 1.5111799 \\
\hline line 10 & 1.5135485 \\
\hline & \\
\hline Average & 1.521365 \\
\hline
\end{tabular}




\section{RSM-FEP-6 CCC}

Photos of RSM-FEP-6 CCC VHT Samples Prior to Testing

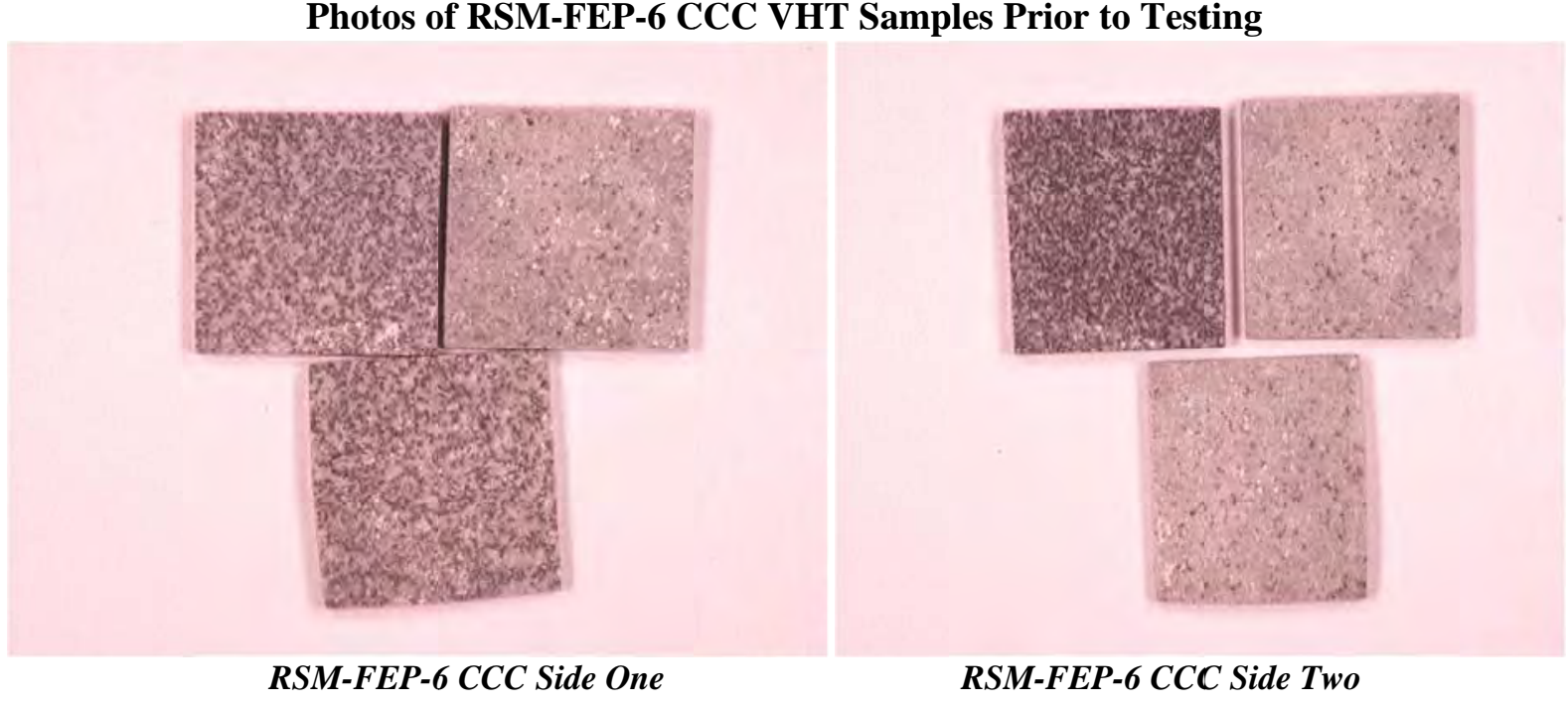

Photos of RSM-FEP-6 CCC VHT Samples Post-Testing

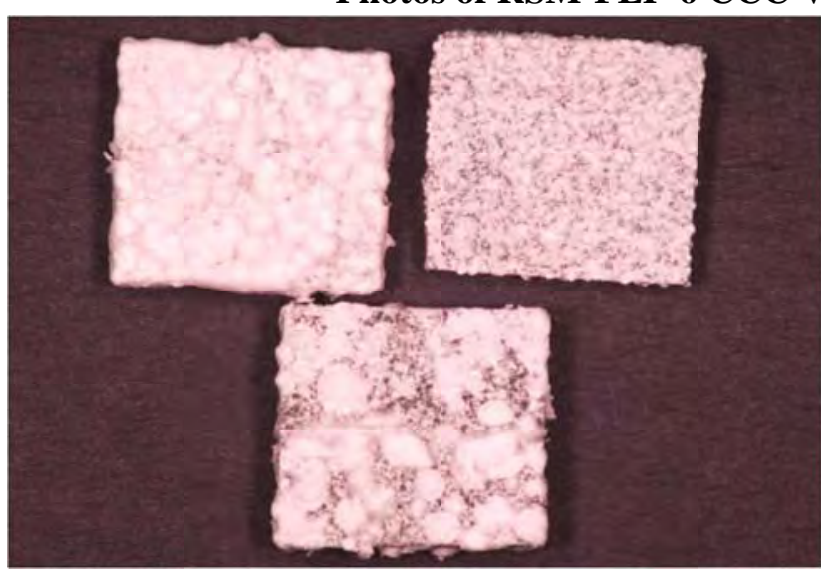

RSM-FEP-6 CCC Side One

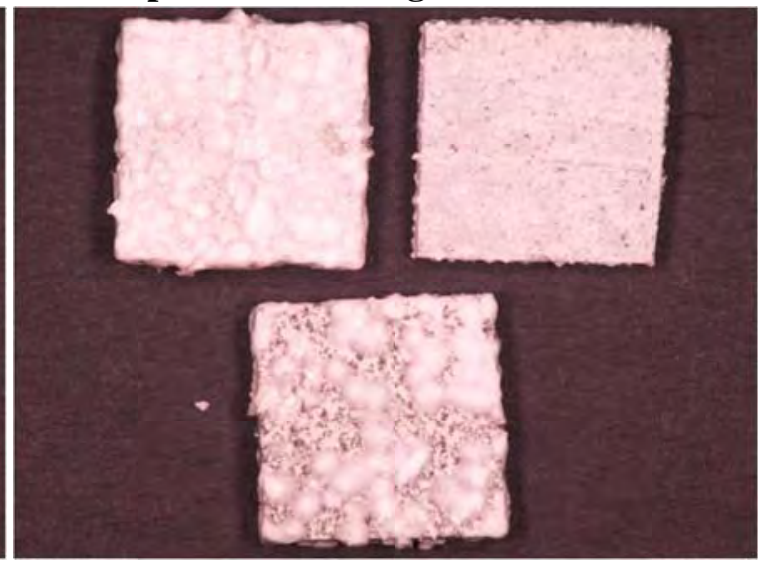

RSM-FEP-6 CCC Side Two 
RSM-FEP-6 CCC (1) Light (SEM images of reacted surface)
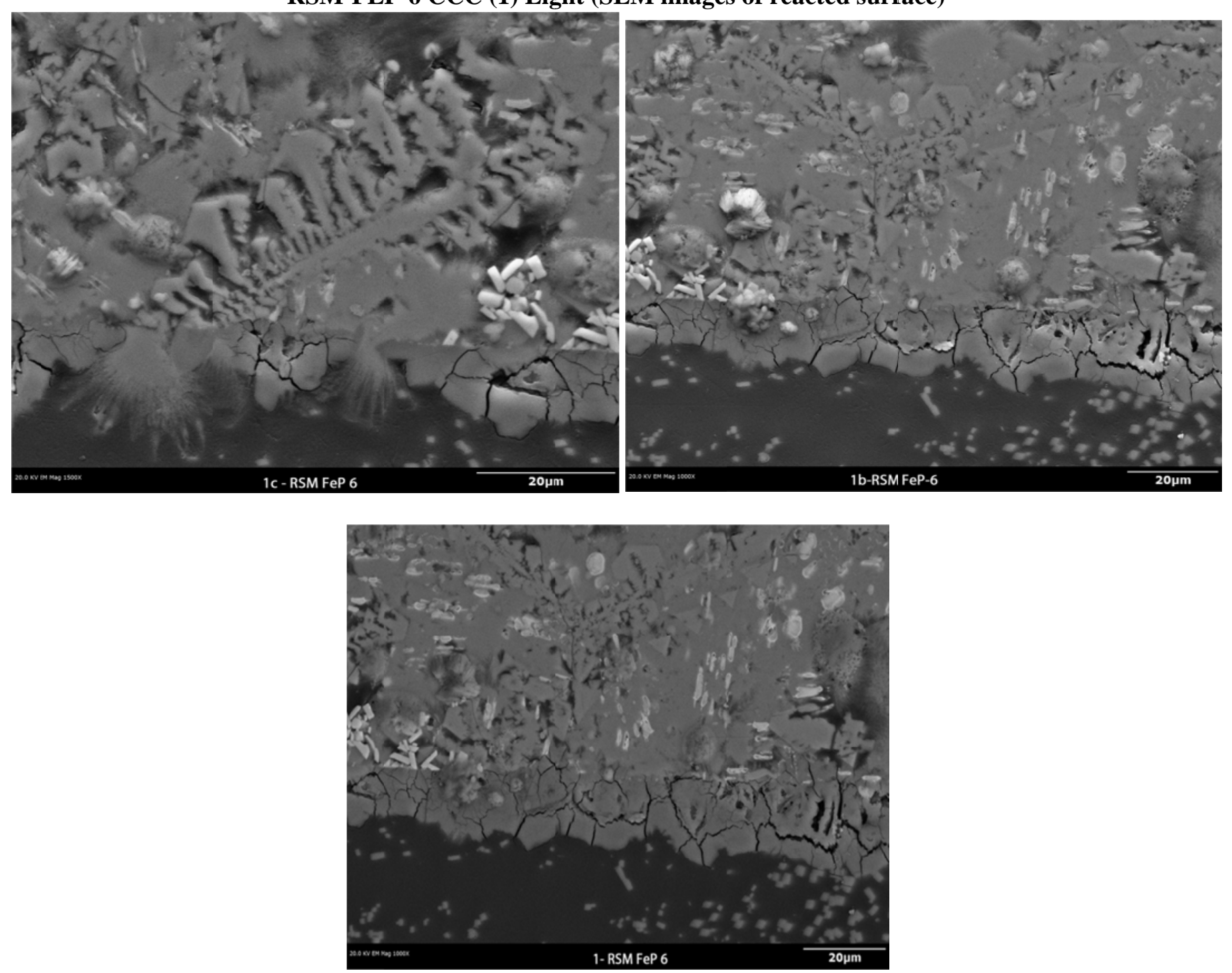
RSM-FEP-6 CCC (1) Light (post-analysis)

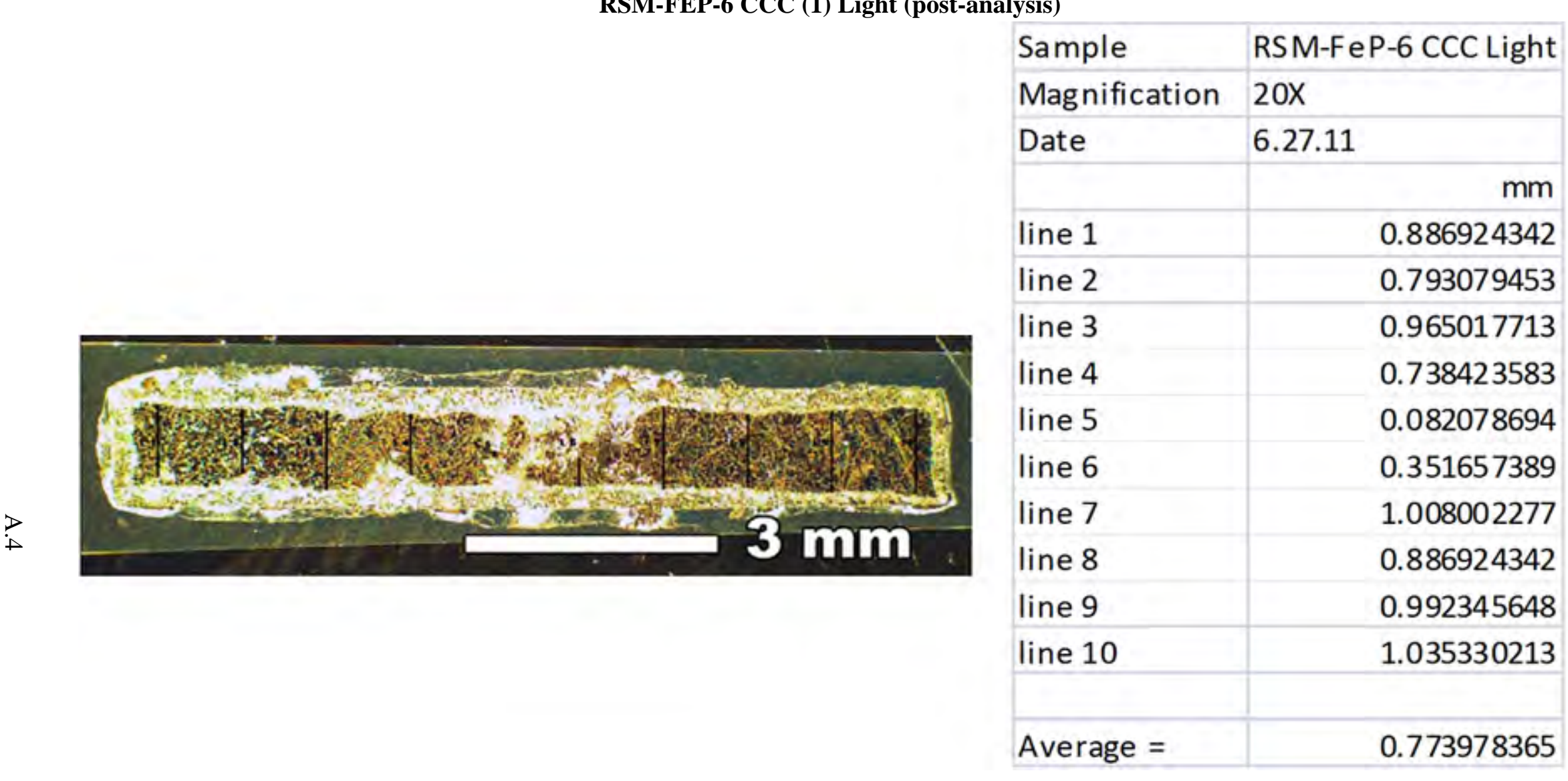


RSM-FEP-6 CCC (2) Dark (SEM images of reacted surfaces)

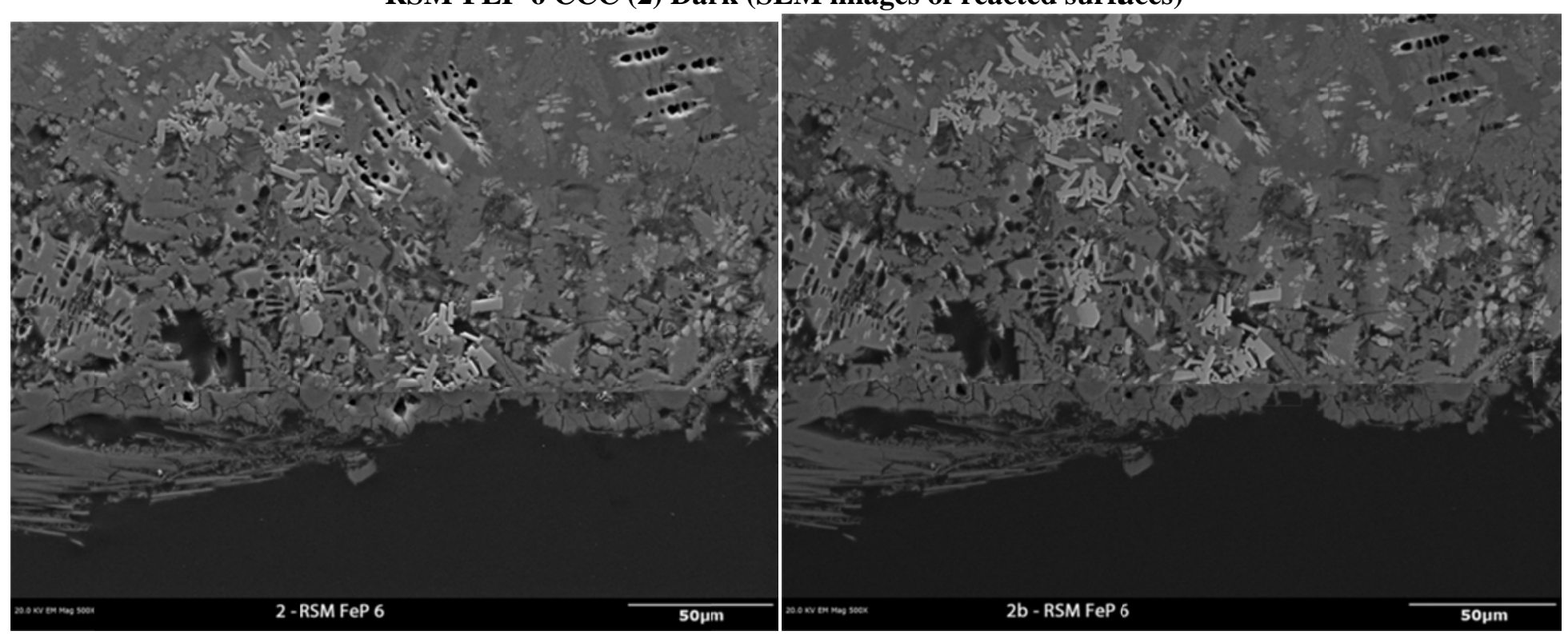




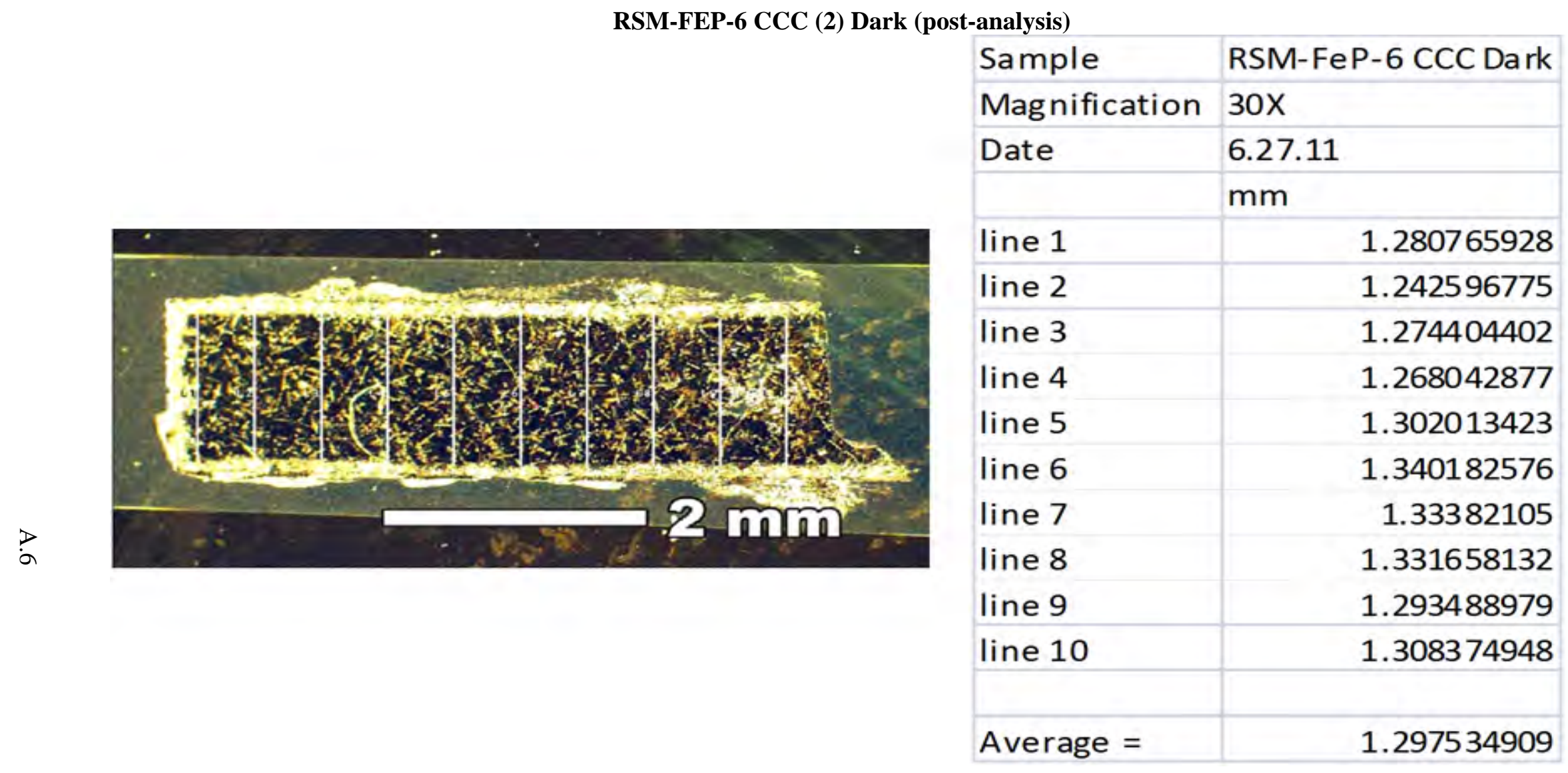


RSM-FEP-6 CCC (3) Light and Dark (SEM images of reacted surfaces)

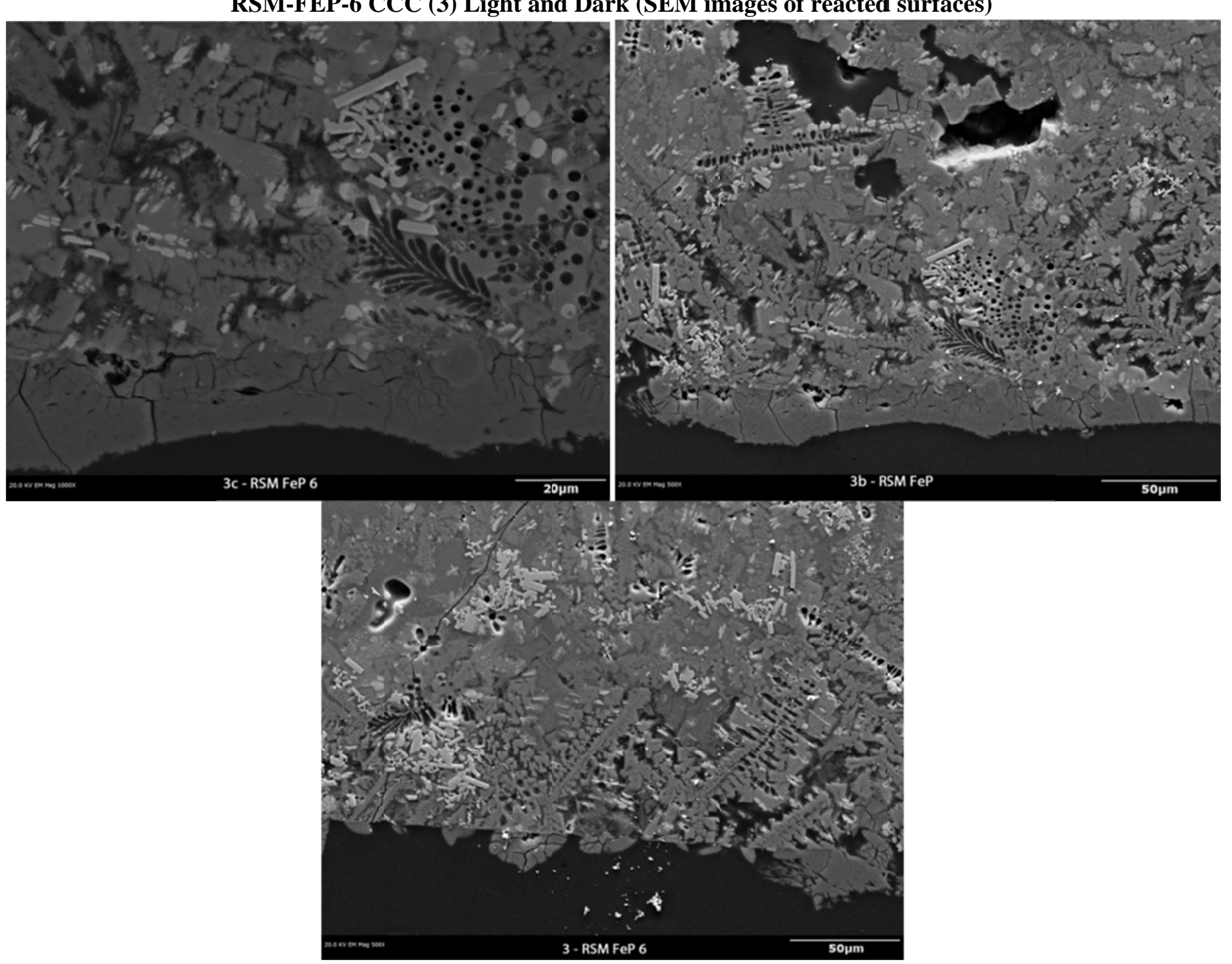




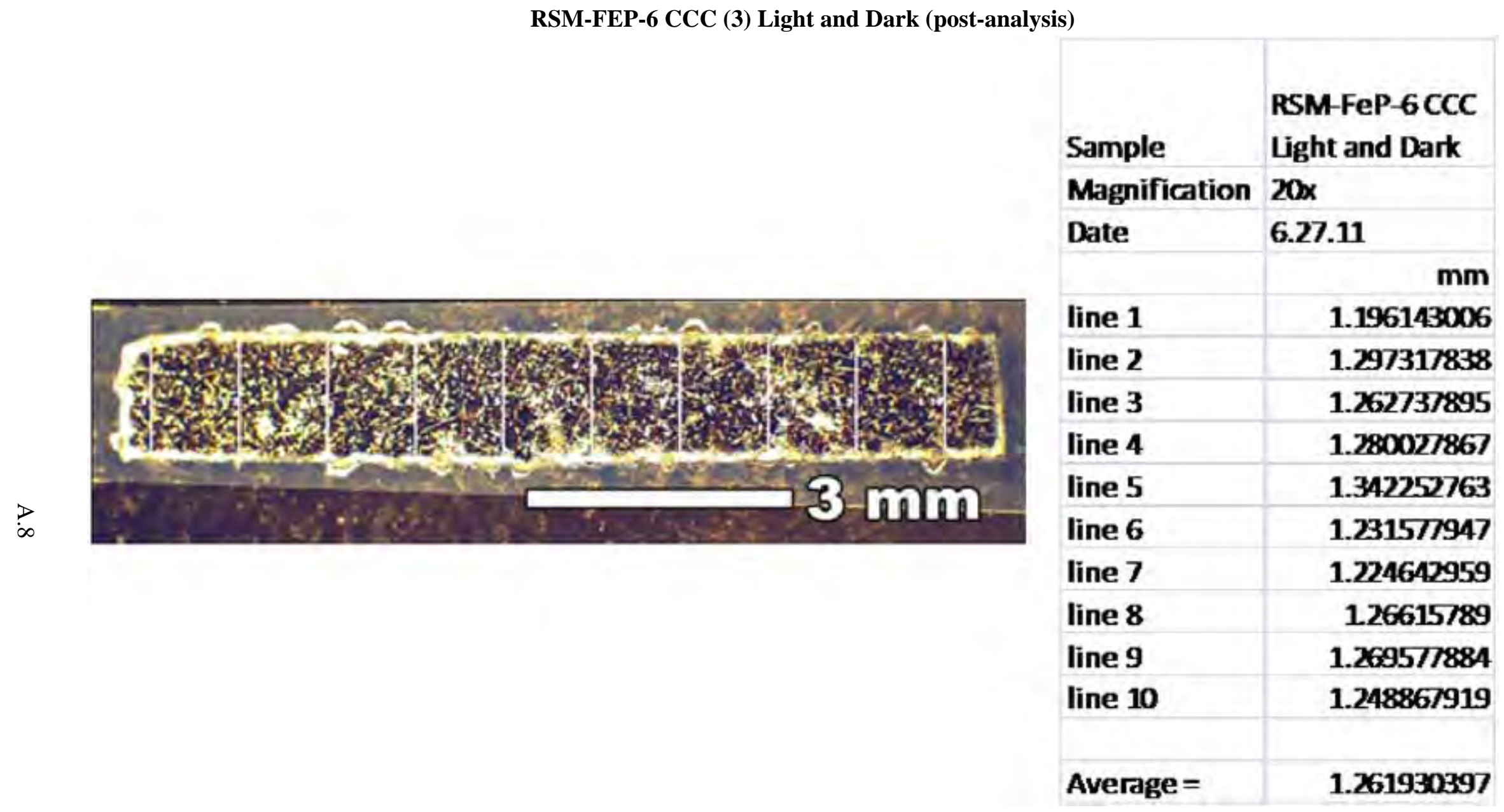


RSM-FEP-16

Photos of RSM-FEP-16 VHT Samples Prior to Testing

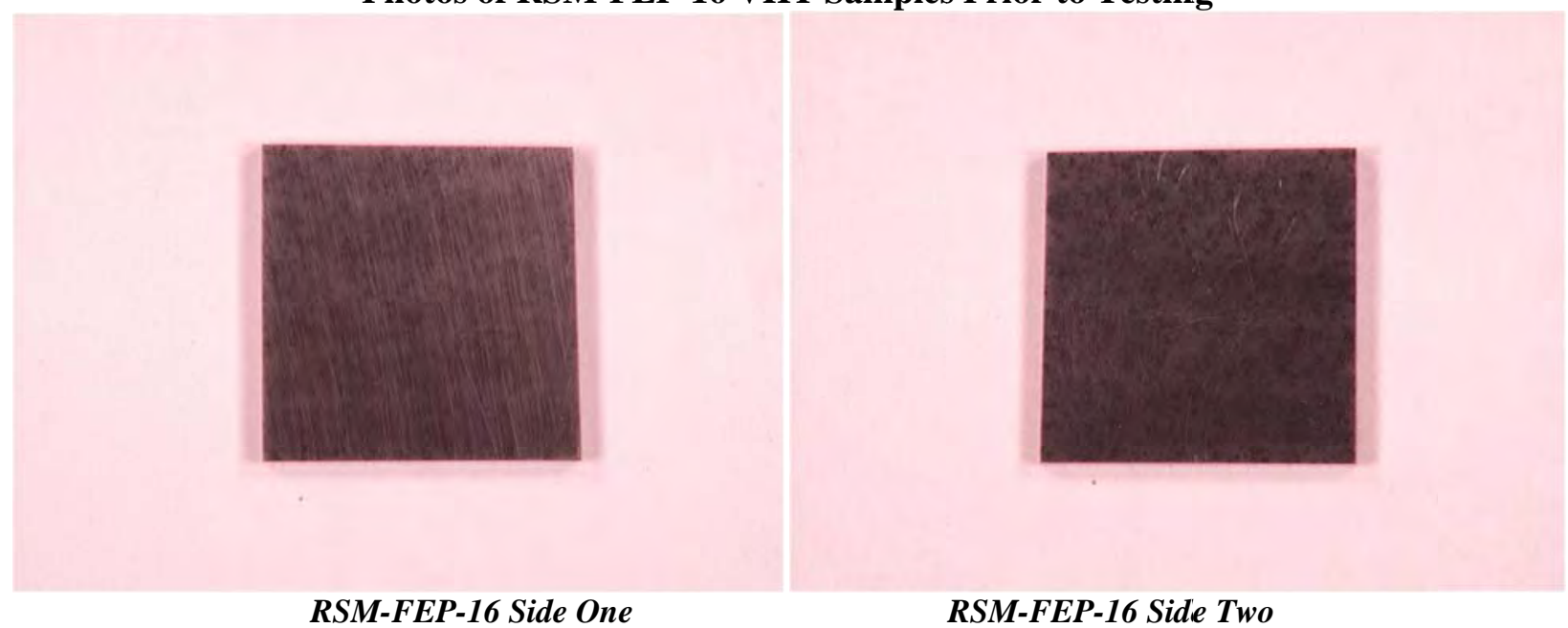

Photos of RSM-FEP-16 VHT Samples Post-Testing

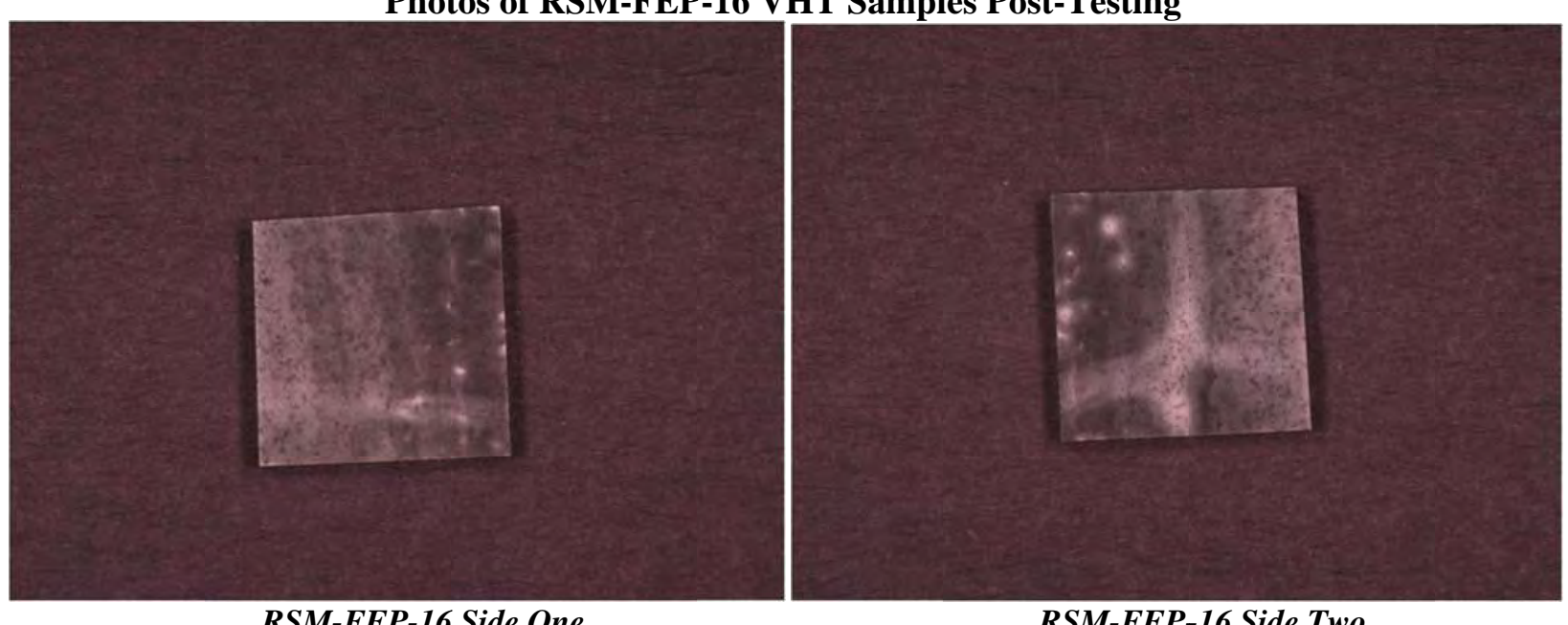

RSM-FEP-16 Side One

RSM-FEP-16 Side Two 


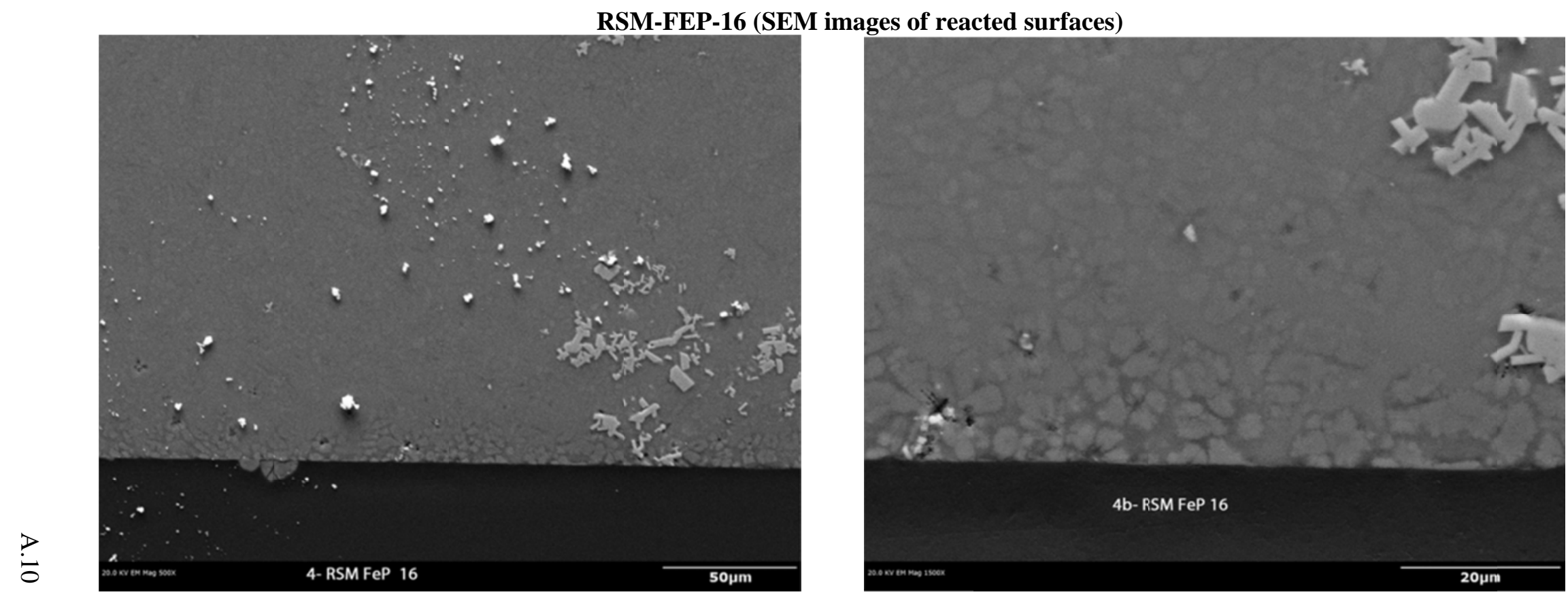


RSM-FEP-16 CCC (post-analysis)

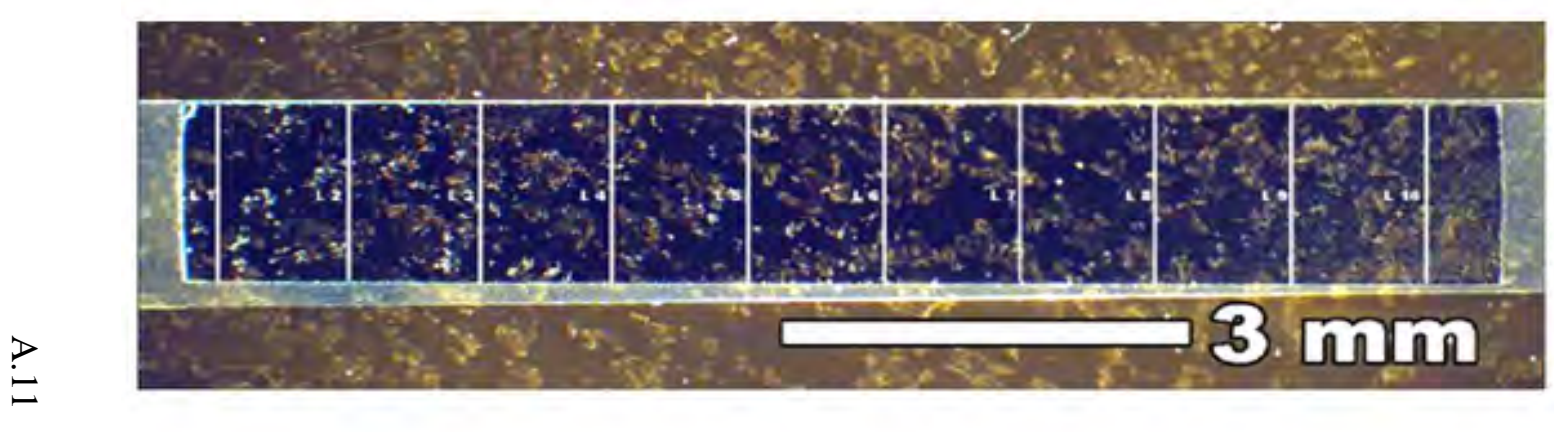

\begin{tabular}{|l|r|}
\hline Sample & RSM-FeP-16 \\
\hline Magnification & \multicolumn{1}{l|}{ 20X } \\
\hline Date & 6.27 .11 \\
\hline & $\mathrm{mm}$ \\
\hline line 1 & 1.48789902 \\
\hline line 2 & 1.51096207 \\
\hline line 3 & 1.54427536 \\
\hline line 4 & 1.53402512 \\
\hline line 5 & 1.53146256 \\
\hline line 6 & 1.50327438 \\
\hline line 7 & 1.51096207 \\
\hline line 8 & 1.50071182 \\
\hline line 9 & 1.52121231 \\
\hline line 10 & 1.4955867 \\
\hline & \\
\hline Average $=$ & 1.51403714 \\
\hline
\end{tabular}




\section{RSM-FEP-31}

RSM-FEP-31 (post-analysis)

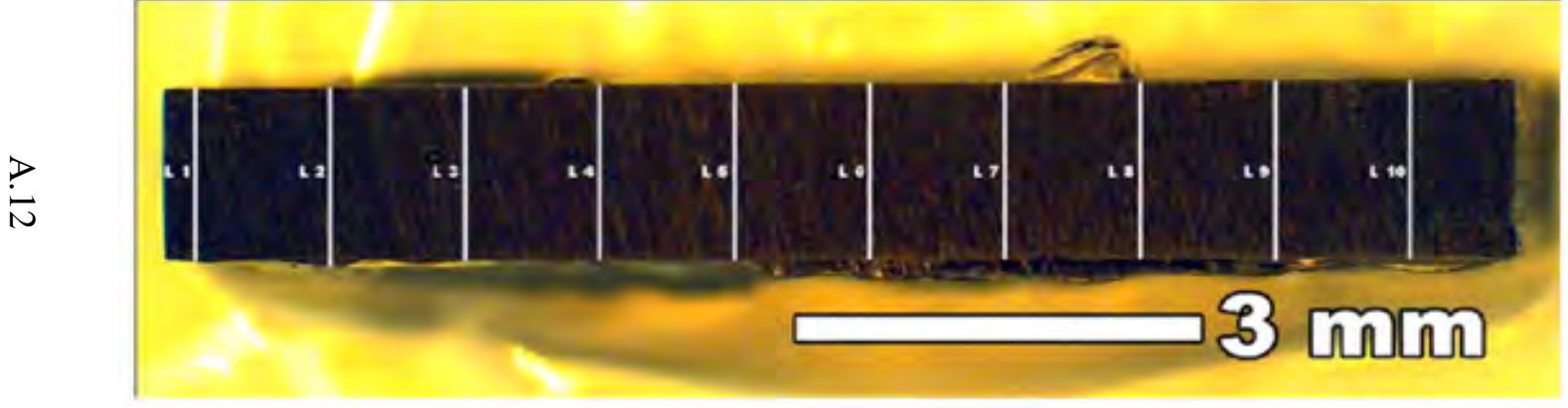

\begin{tabular}{|l|r|}
\hline Sample & RSM-FeP-31 \\
\hline Magnification & \multicolumn{1}{|l}{ 20X } \\
\hline Date & 7.1 .11 \\
\hline & $\mathrm{mm}$ \\
\hline Line 1 & 1.374319706 \\
\hline Line 2 & 1.419883559 \\
\hline Line 3 & 1.380394887 \\
Line 4 & 1.386470067 \\
Line 5 & 1.401658018 \\
\hline Line 6 & 1.413808379 \\
\hline Line 7 & 1.410770789 \\
\hline Line 8 & 1.407733198 \\
\hline Line 9 & 1.43203392 \\
\hline Line 10 & 1.419883559 \\
\hline Average $=$ & 1.404695608 \\
\hline
\end{tabular}




\section{RSM-FEP 54A}

Photos of RSM-FEP-54A VHT Samples Post-Testing
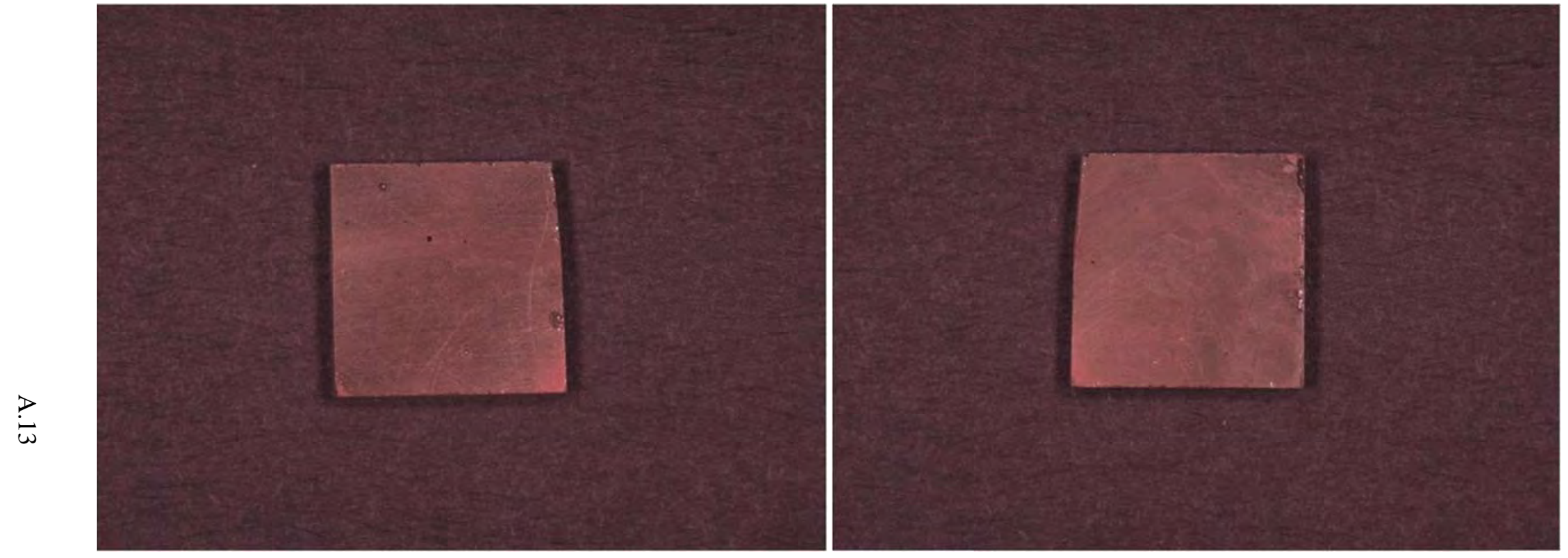

Post-VHT RSM-FEP-54A Side One

Post-VHT RSM-FEP-54A Side Two 


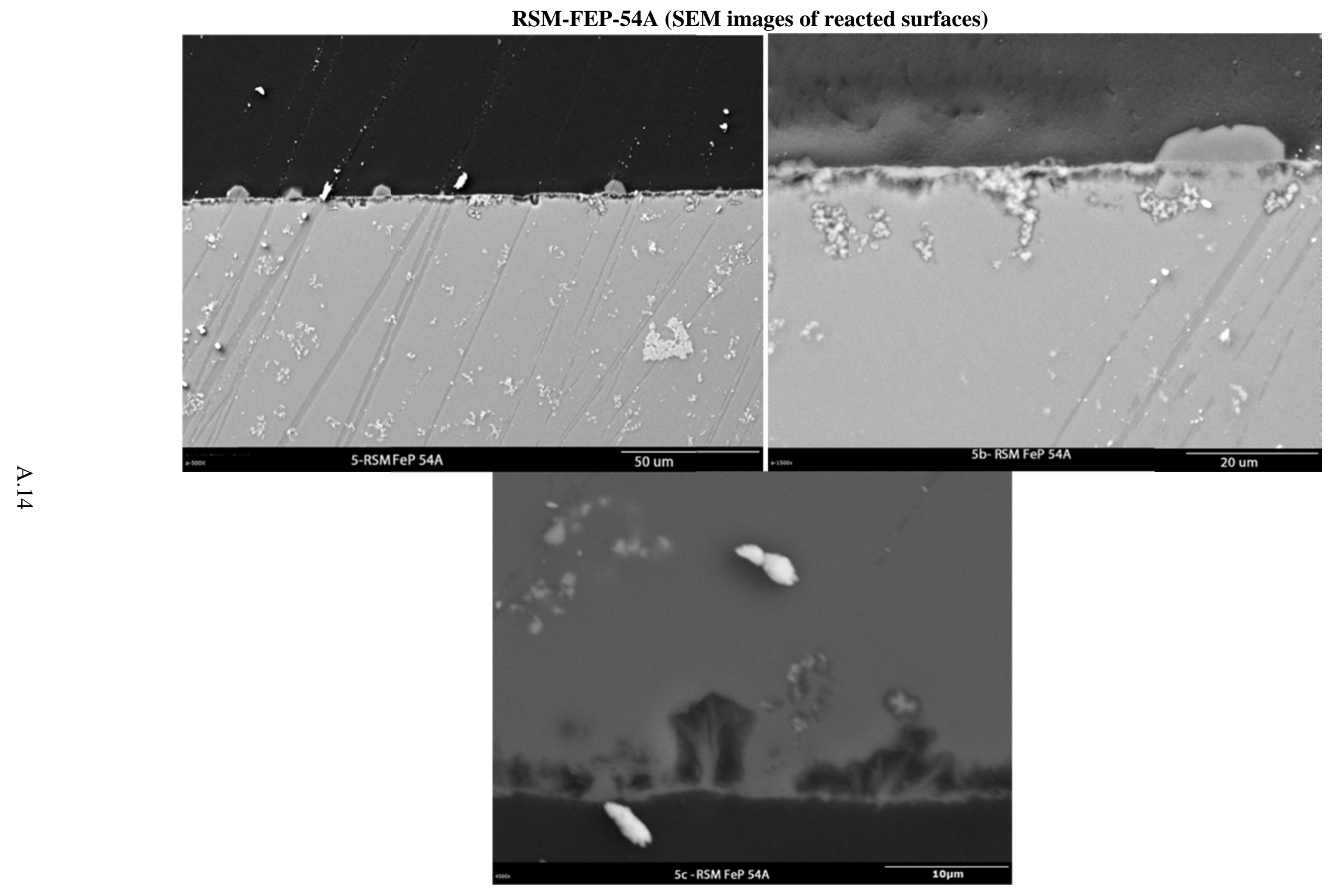


RSM-FEP-54A (post-analysis)

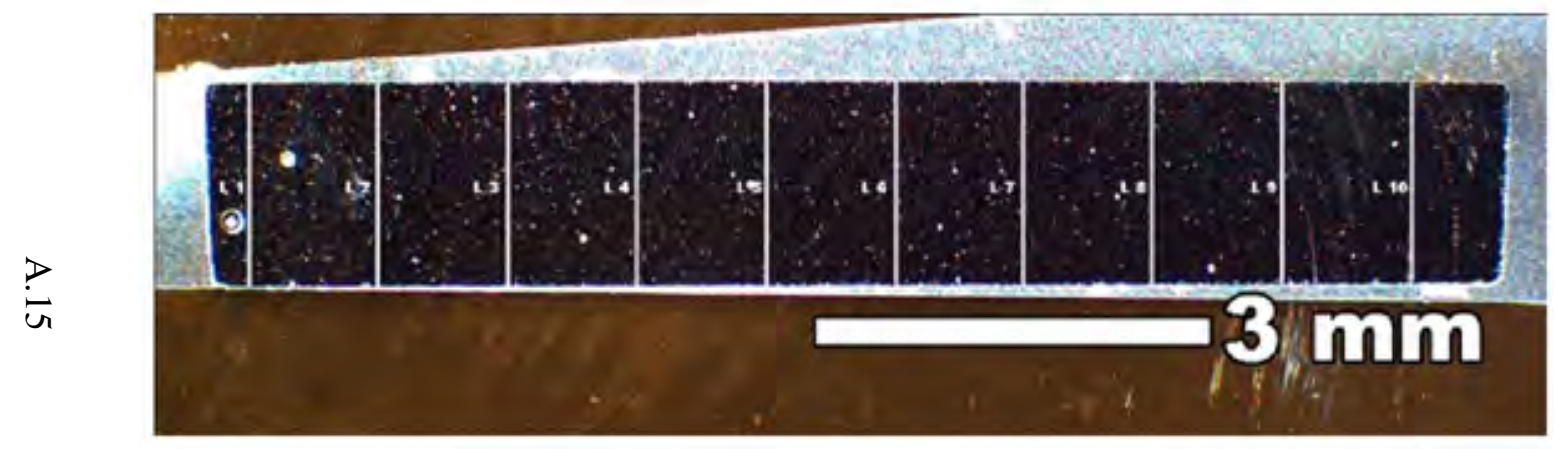

\begin{tabular}{|l|l|}
\hline Sample & RSM-FeP-54A \\
\hline Magnification & $20 \mathrm{X}$ \\
\hline Date & 6.27 .11 \\
\hline & $\mathrm{mm}$ \\
\hline Line 1 & 1.508440286 \\
\hline Line 2 & 1.508440286 \\
\hline Line 3 & 1.511949169 \\
\hline Line 4 & 1.501327685 \\
\hline Line 5 & 1.508440286 \\
\hline Line 6 & 1.515458051 \\
\hline Line 7 & 1.508440286 \\
\hline Line 8 & 1.508440286 \\
\hline Line 9 & 1.511949169 \\
\hline Line 10 & 1.49430992 \\
\hline Average $=$ & 1.507719542 \\
\hline
\end{tabular}


RSM-FEP-54A CCC

Photos of RSM-FEP-54A CCC VHT Samples Prior to Testing

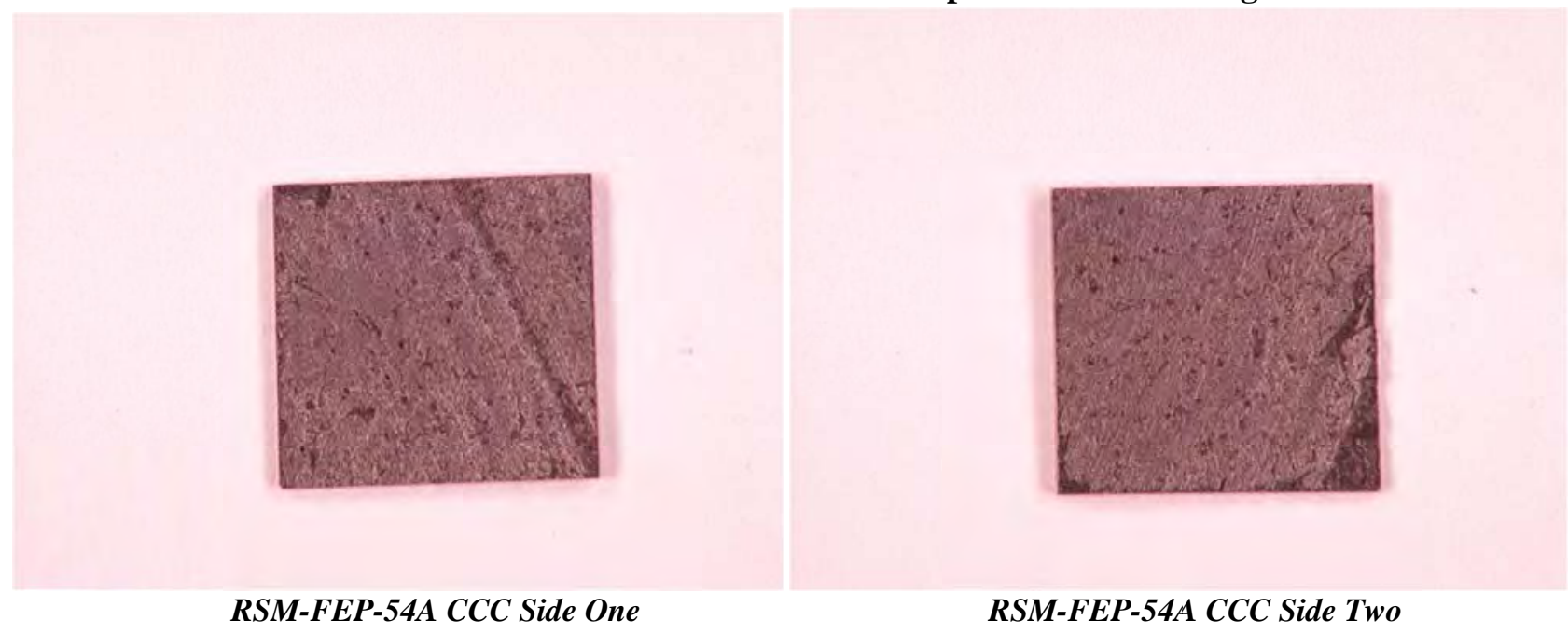

Photos of RSM-FEP-54A CCC VHT Samples Post-Testing

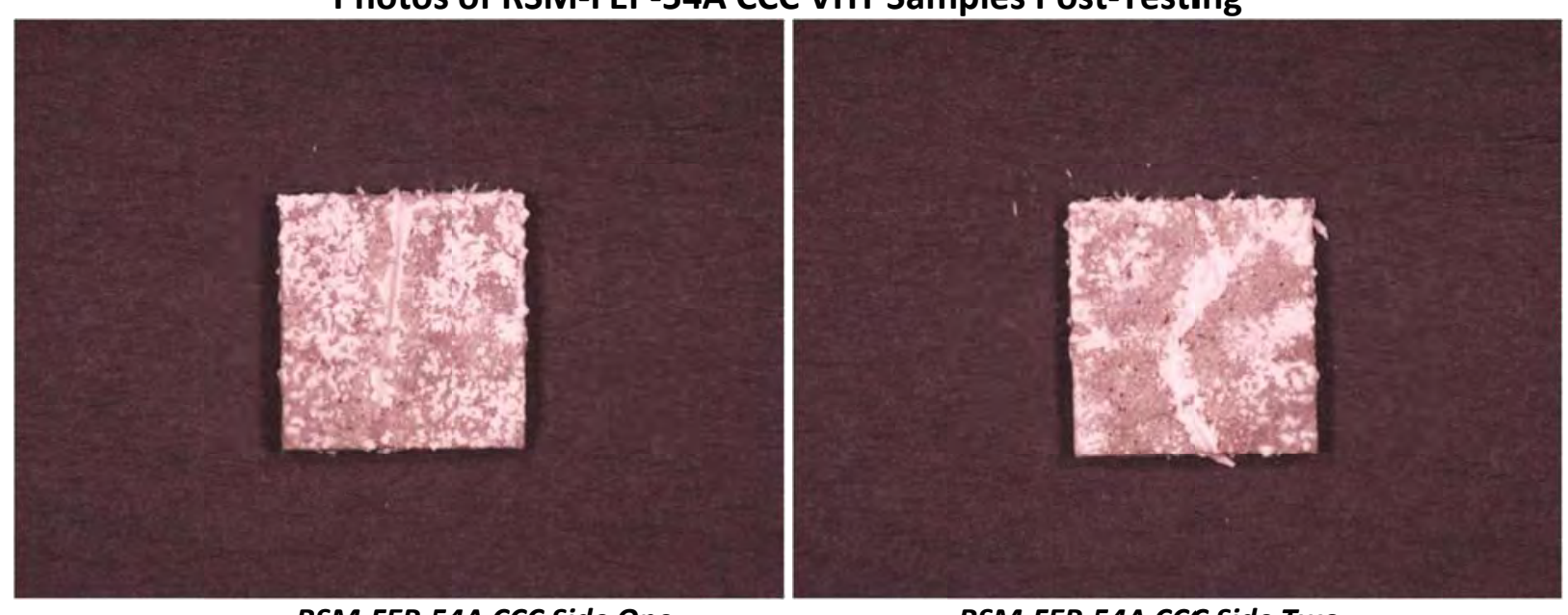

RSM-FEP-54A CCC Side One

RSM-FEP-54A CCC Side Two 
RSM-FEP-54A CCC (SEM images of reacted surfaces)
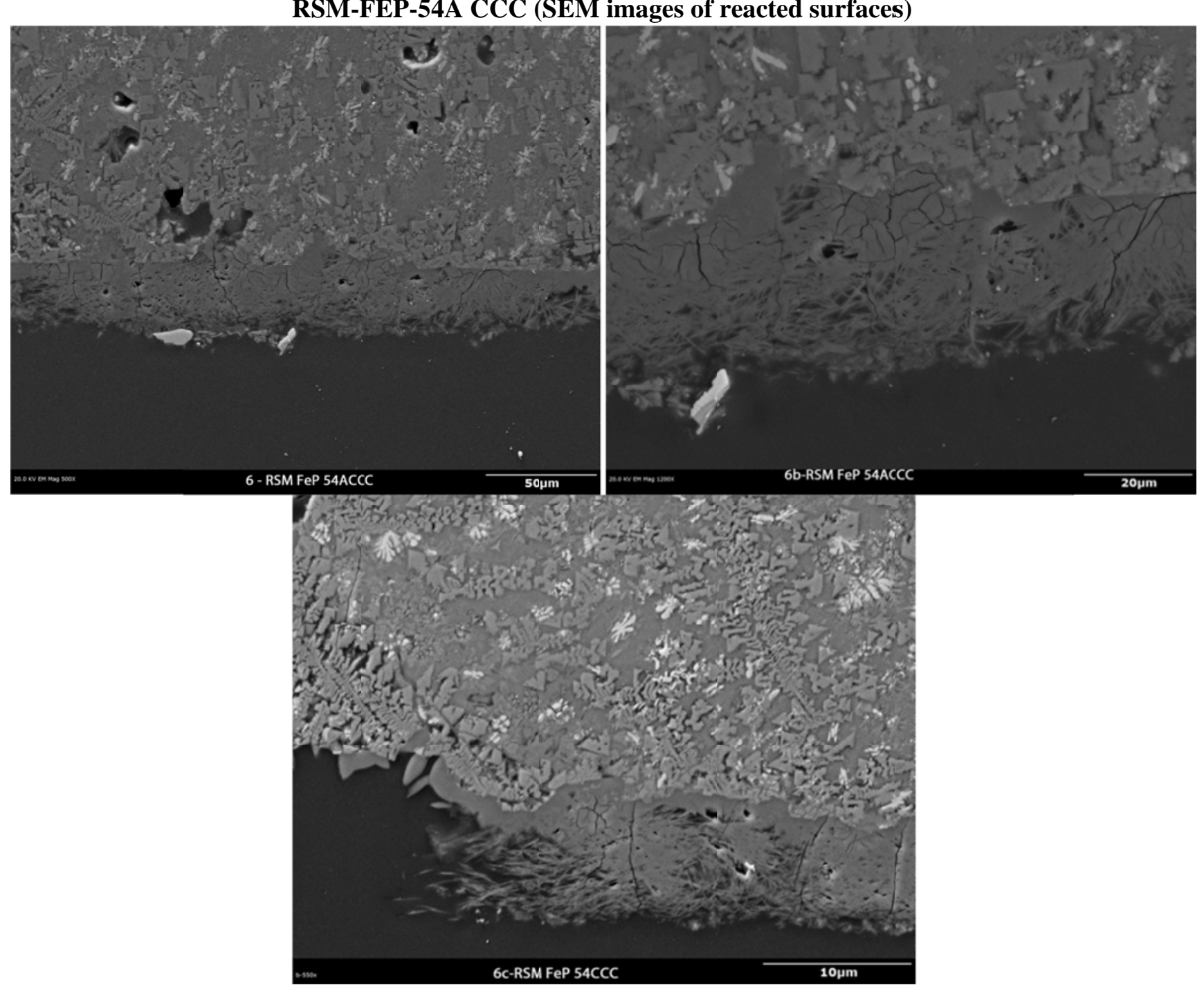


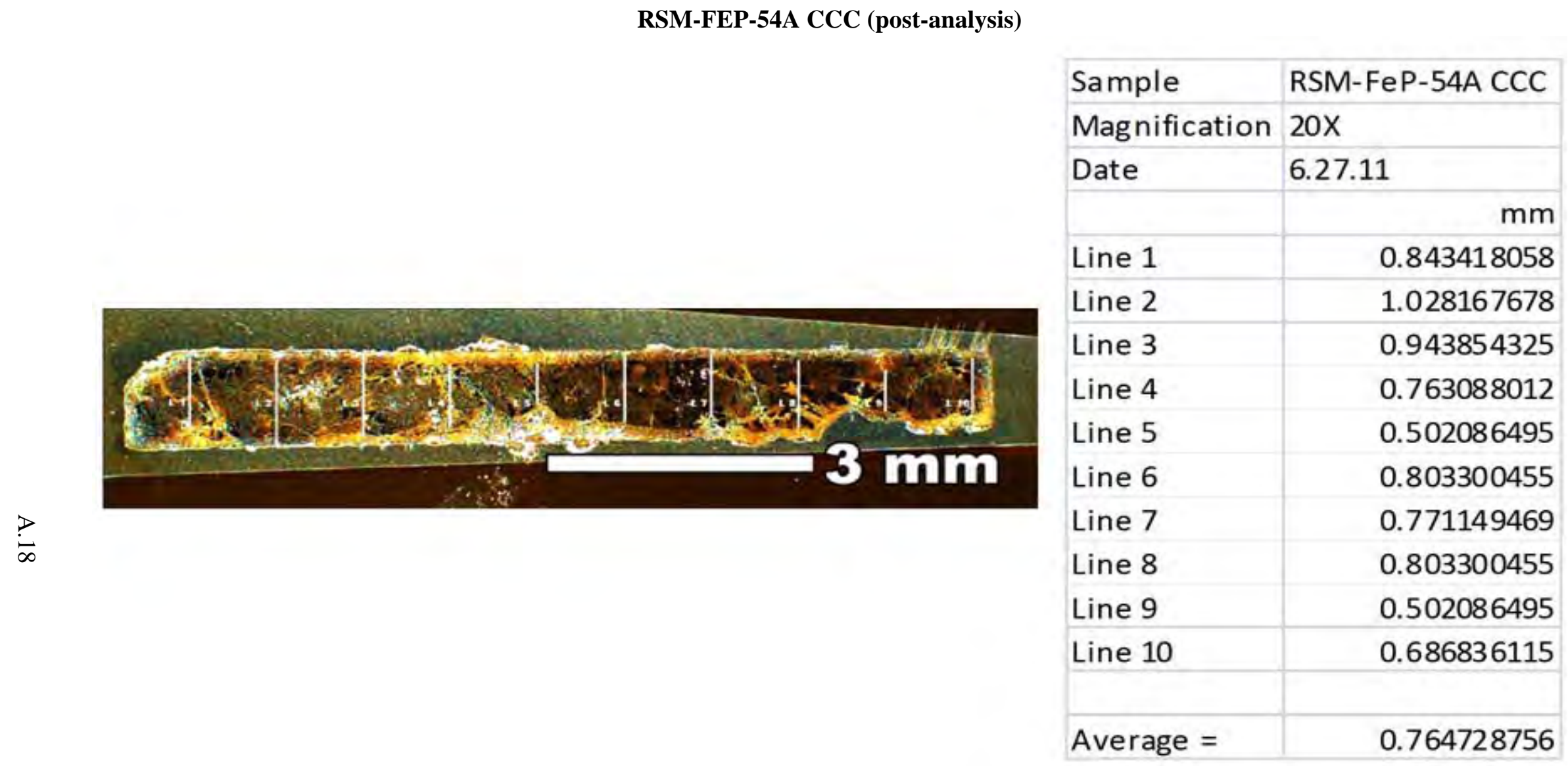


RSM-FEP 63A CCC

Photos of RSM-FEP-63A CCC VHT Samples Prior to Testing

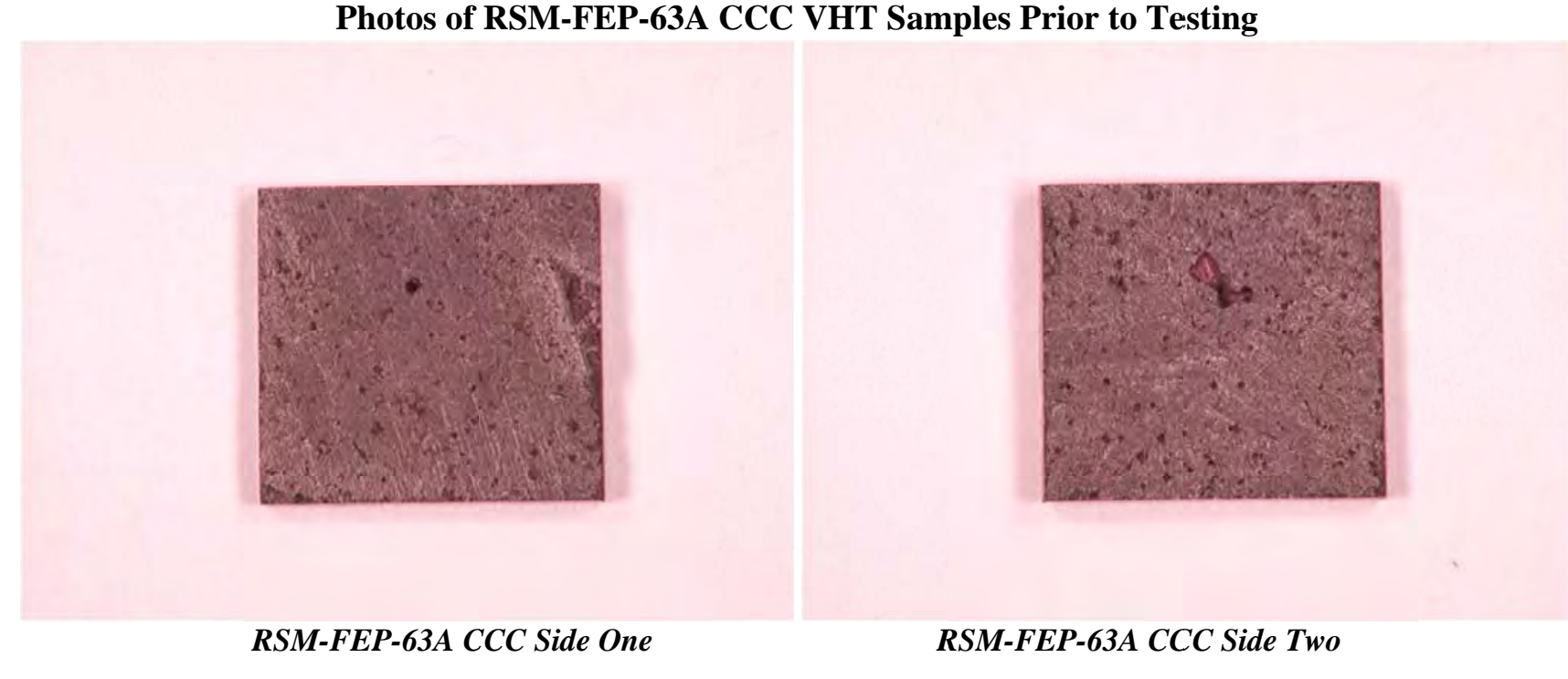

Photos of RSM-FEP-63A CCC VHT Samples Post-Testing

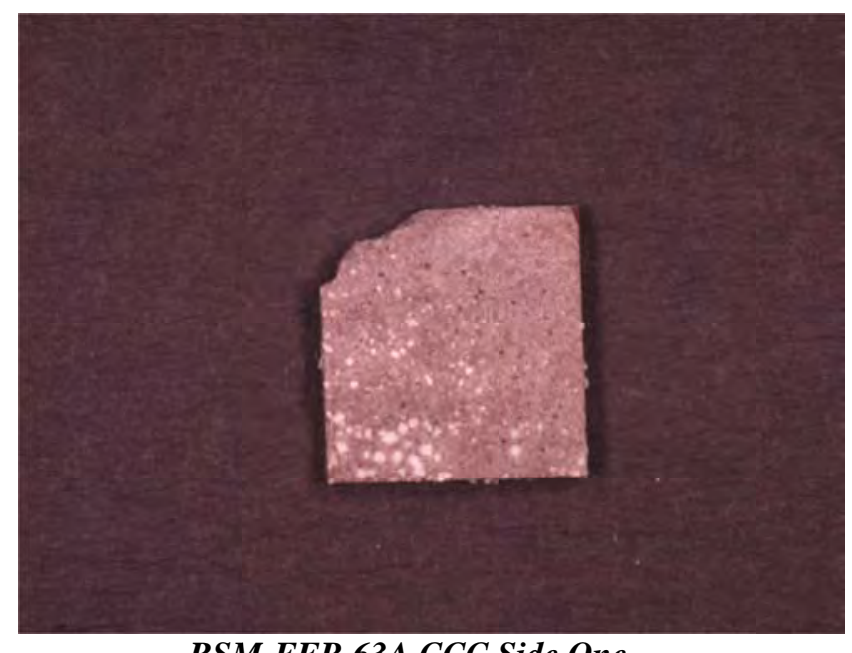

RSM-FEP-63A CCC Side One

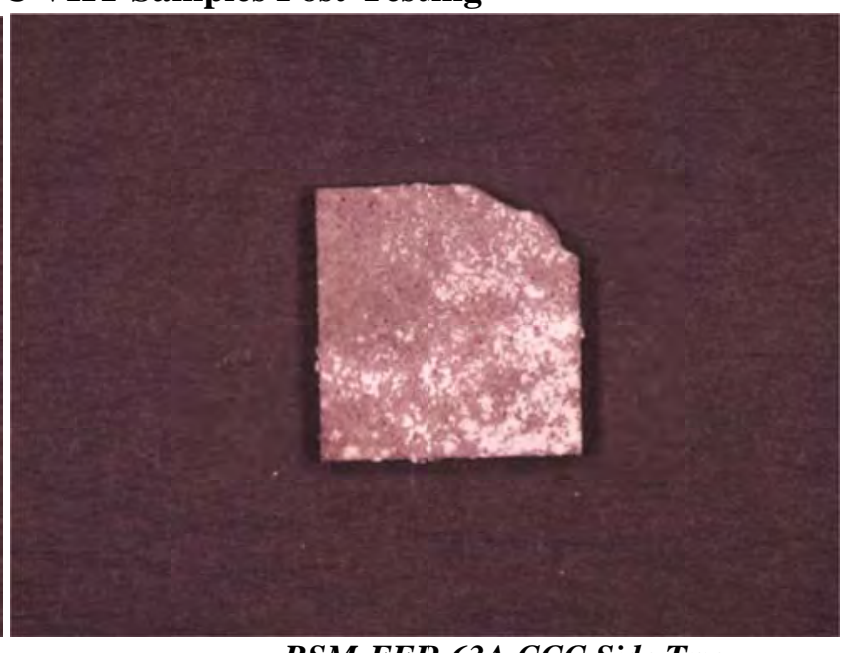

RSM-FEP-63A CCC Side Two 
RSM-FEP-63A CCC (SEM images of reacted surfaces)
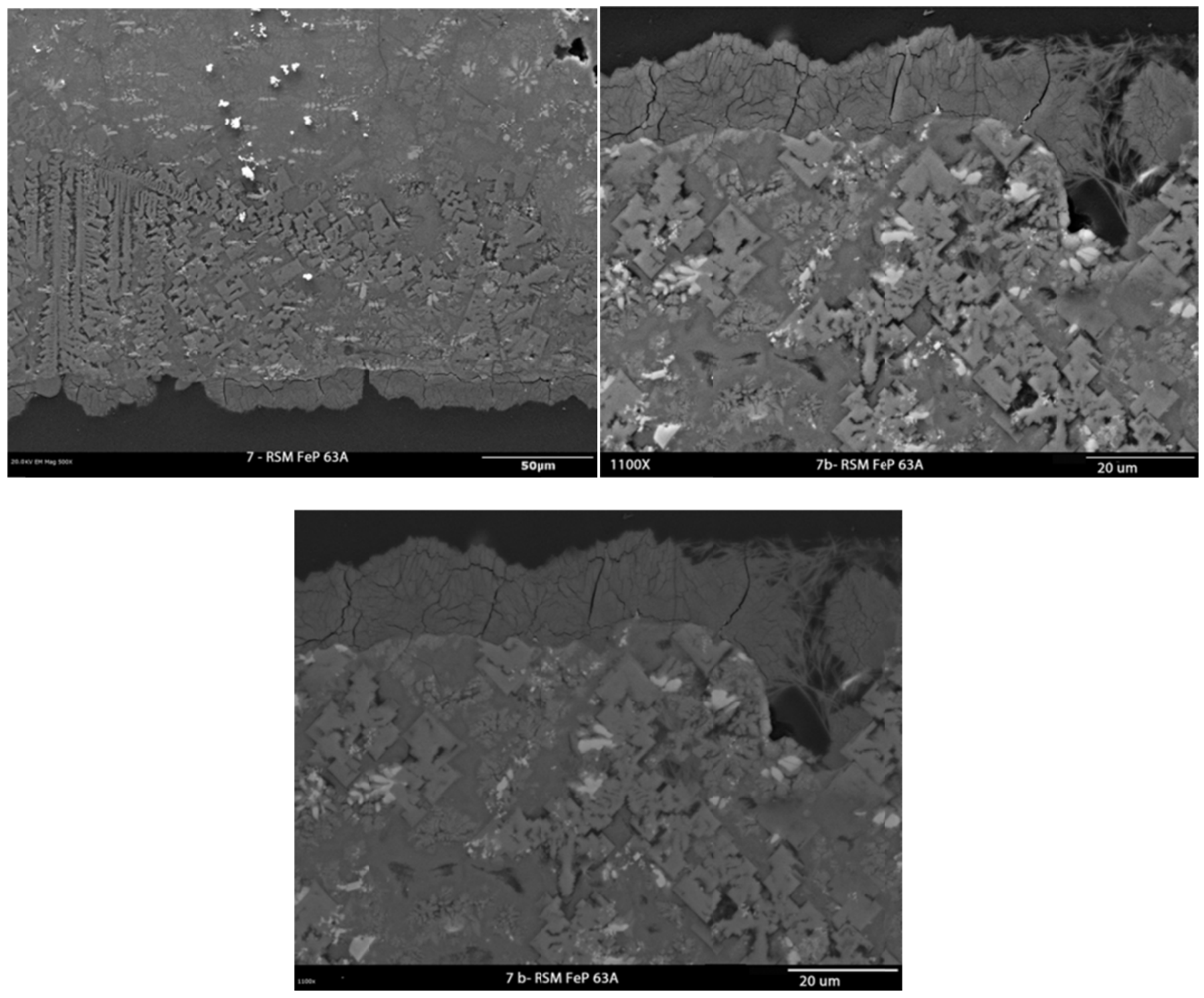
RSM-FEP-63A CCC (post-analysis)

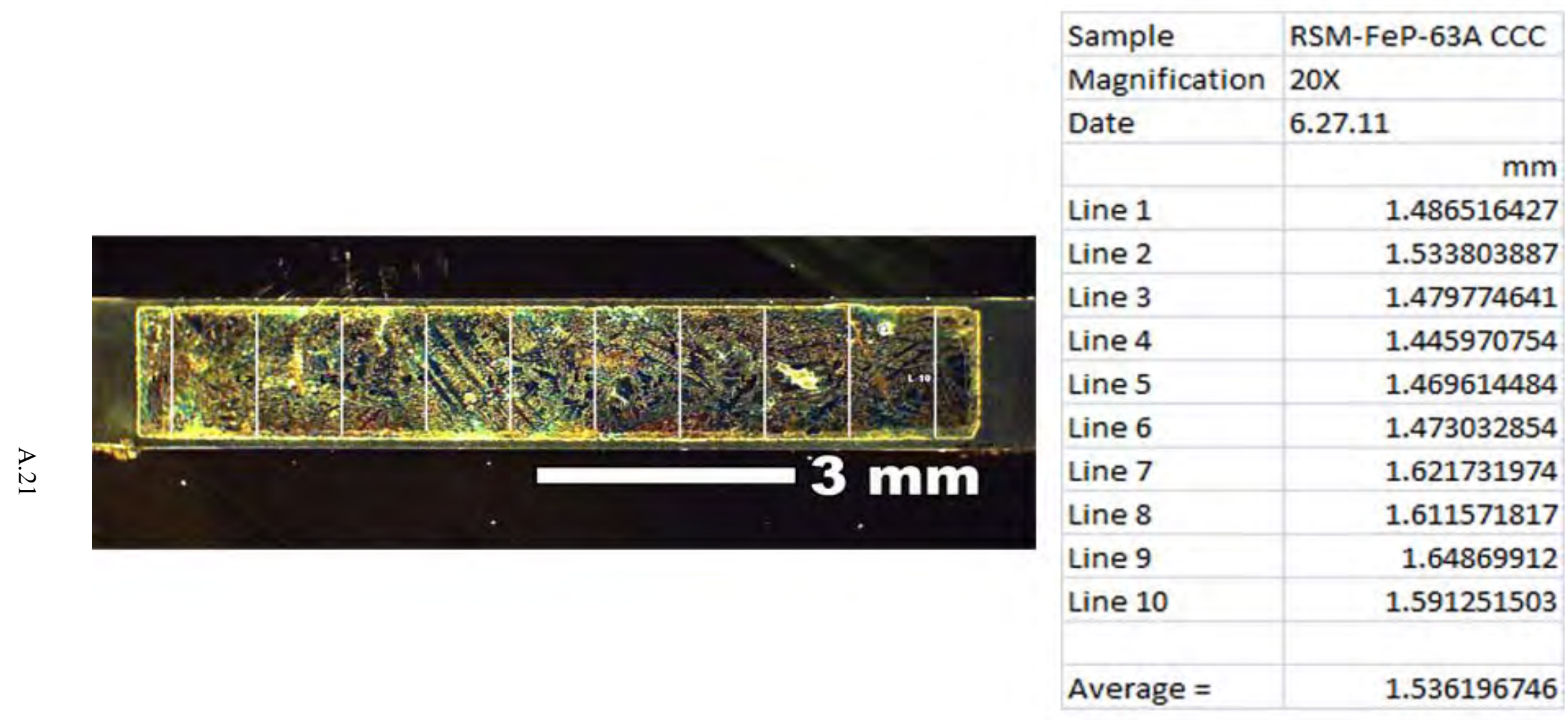


RSM-FEP-70 CCC

Photos of RSM-FEP-70 CCC VHT Samples Prior to Testing

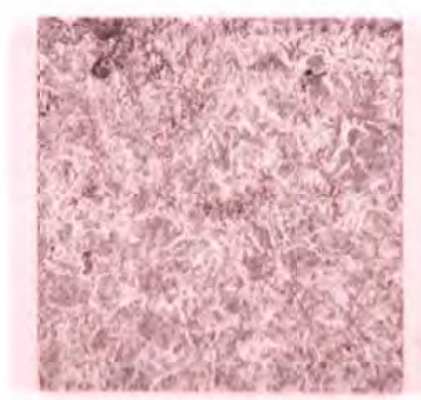

RSM-FEP-70 CCC Side One

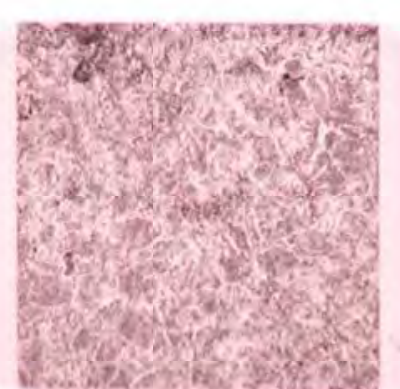

RSM-FEP-70 CCC Side Two

Photos of RSM-FEP-70 CCC VHT Samples Post-Testing

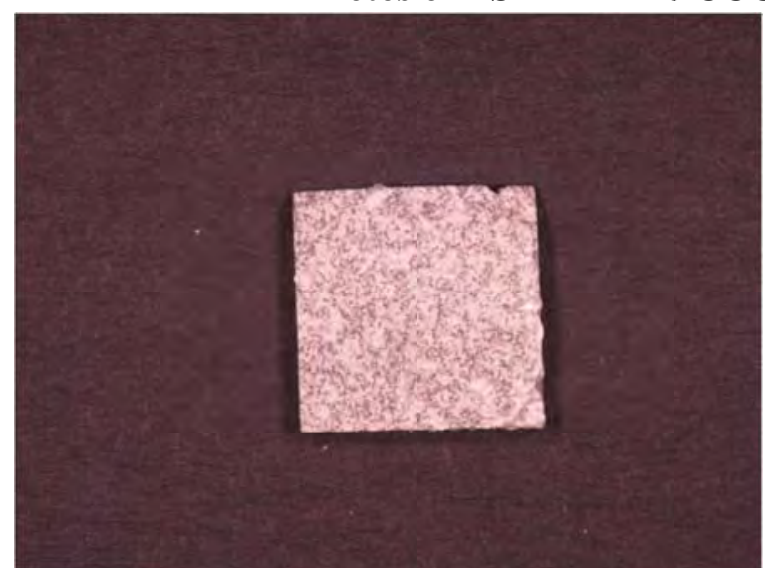

RSM-FEP-70 CCC Side One

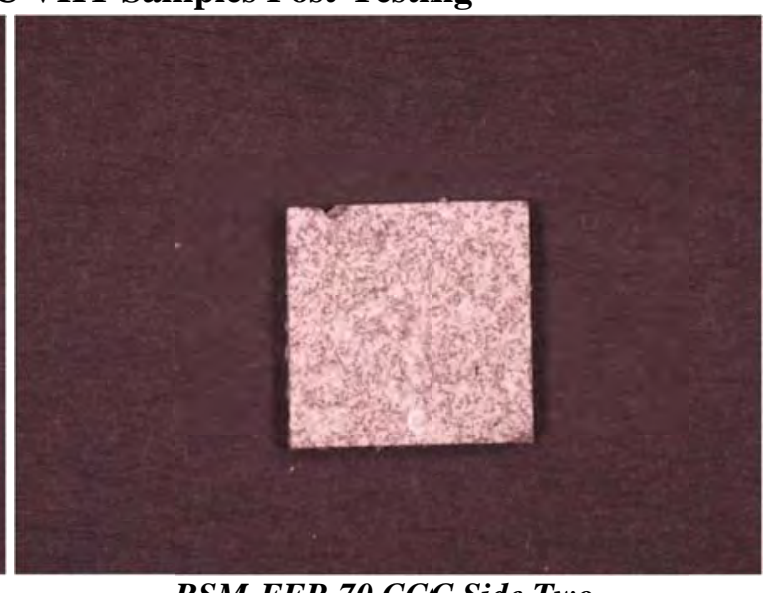

RSM-FEP-70 CCC Side Two 


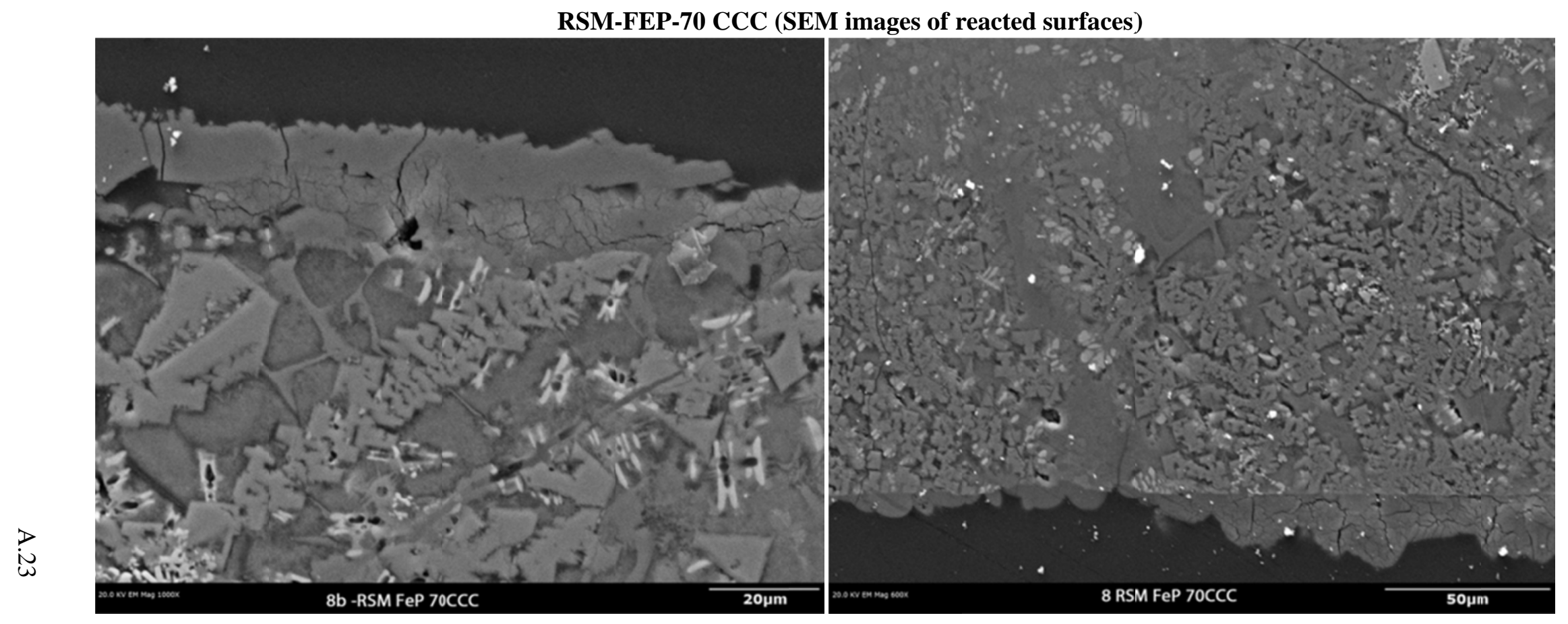


RSM-FEP-70 CCC (post-analysis)

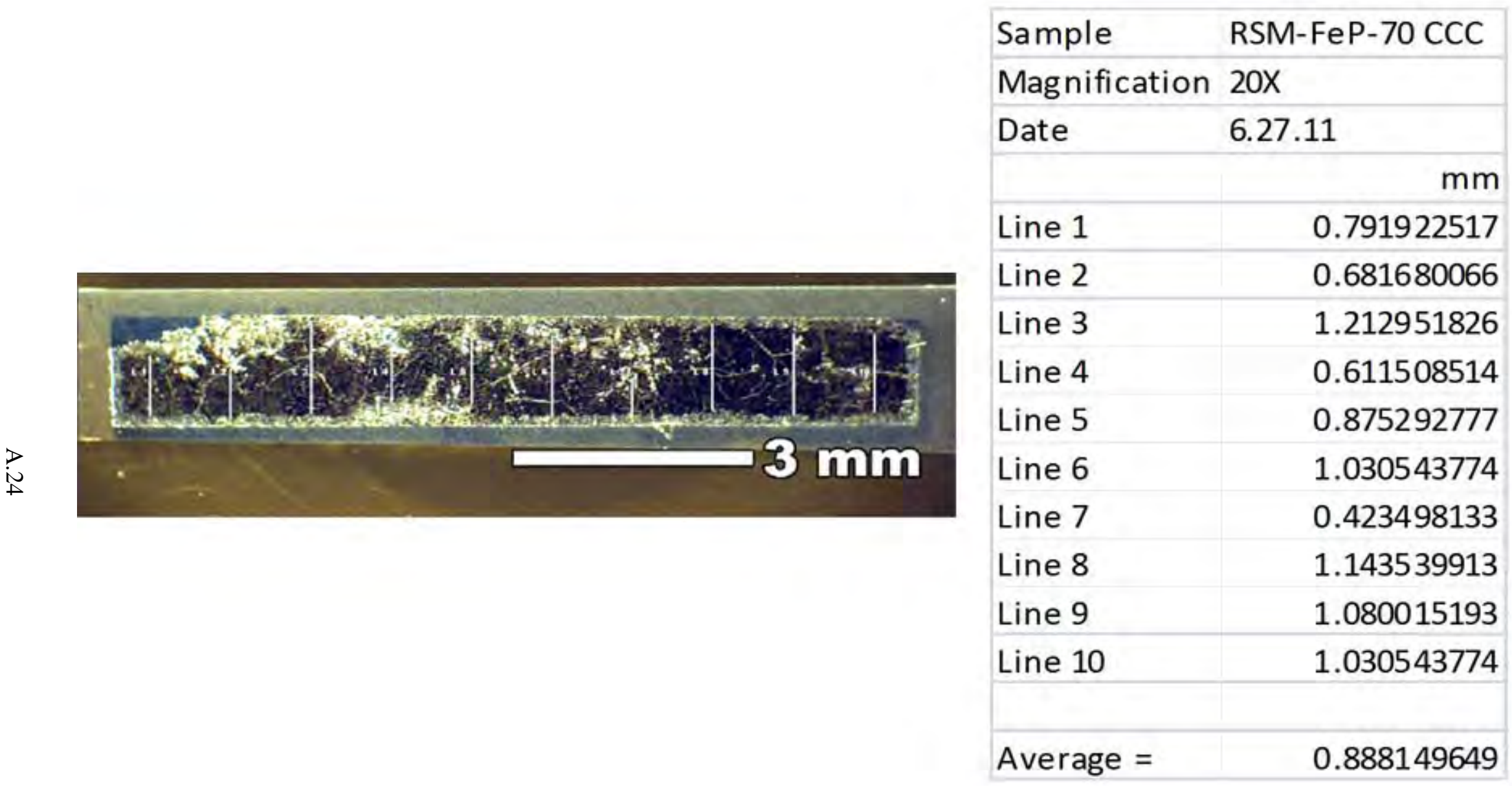


Appendix B

\section{XRD Analysis}





\section{Appendix B}

\section{XRD Analysis}

RSM-FEP-7

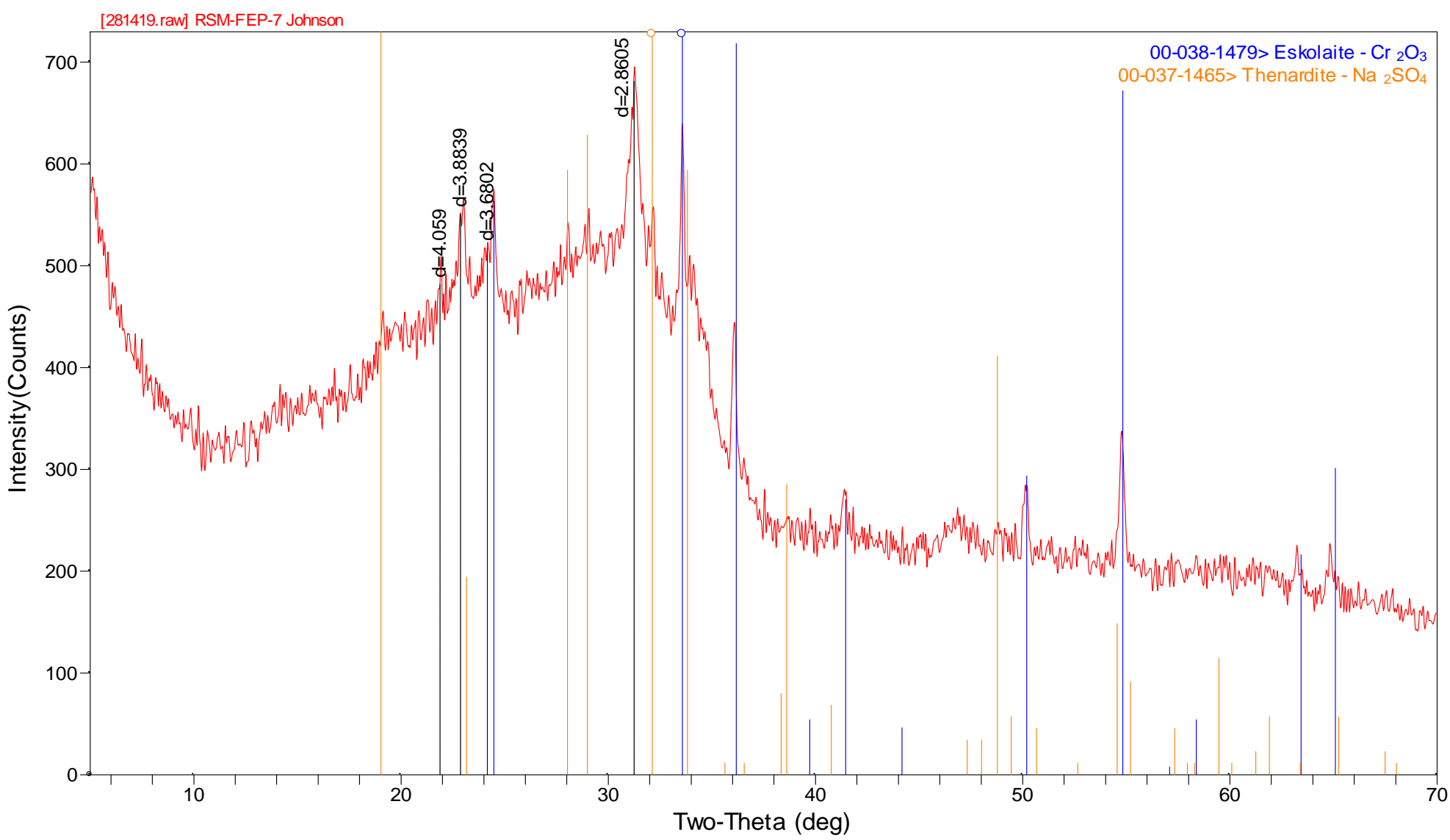




\section{RSM-FEP-15}

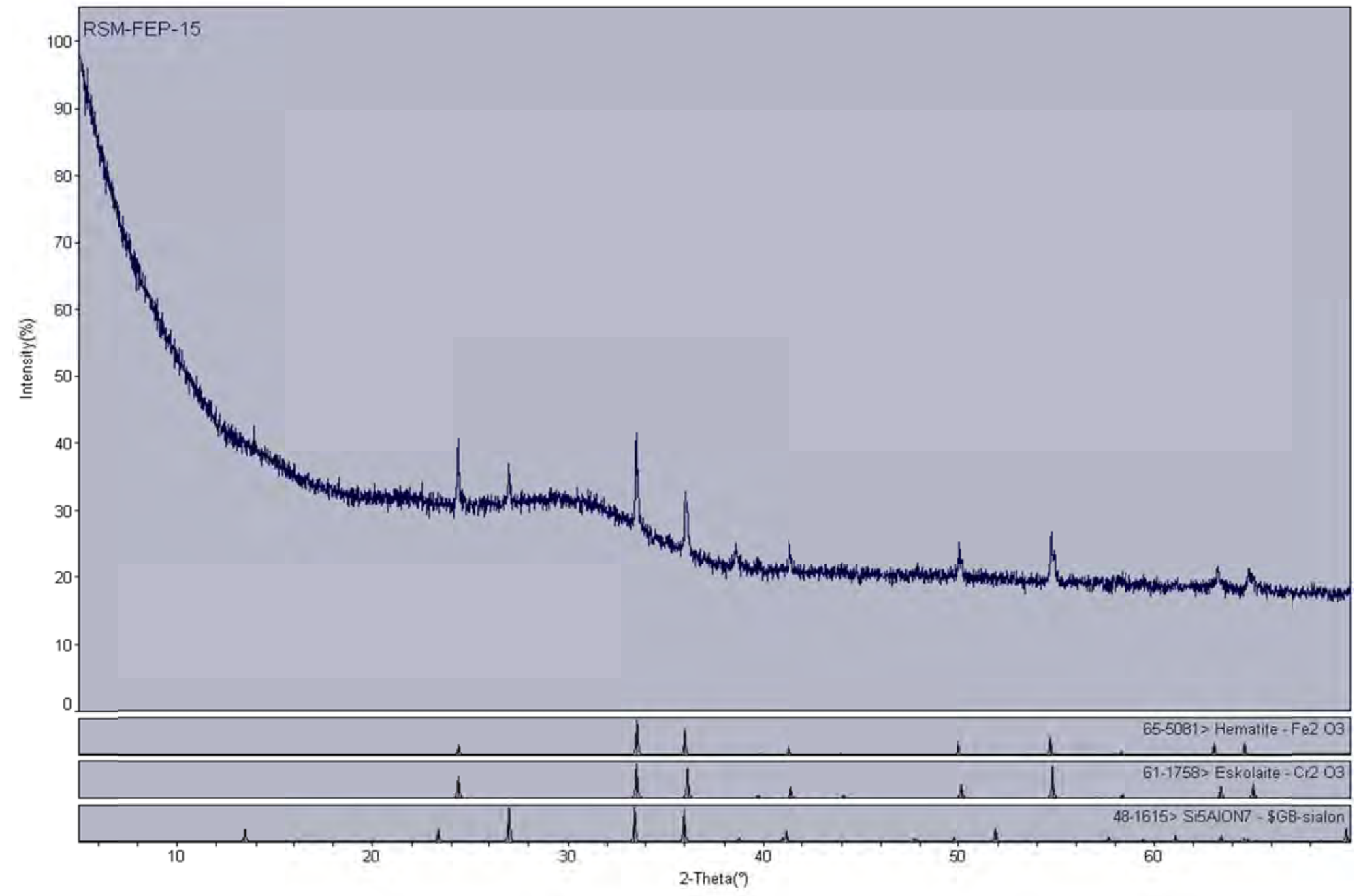




\section{RSM-FEP-15}

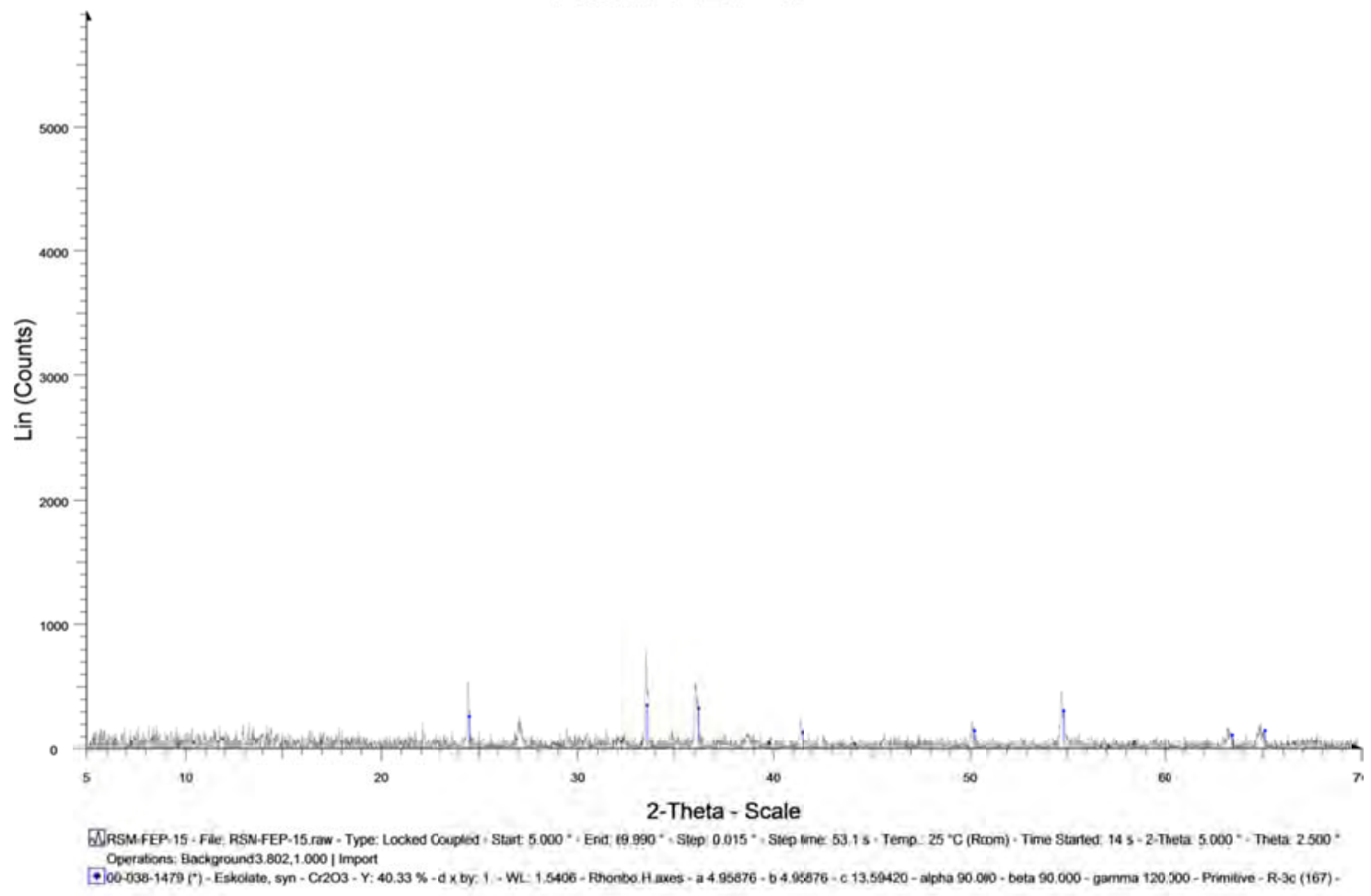

RSM-FEP-15

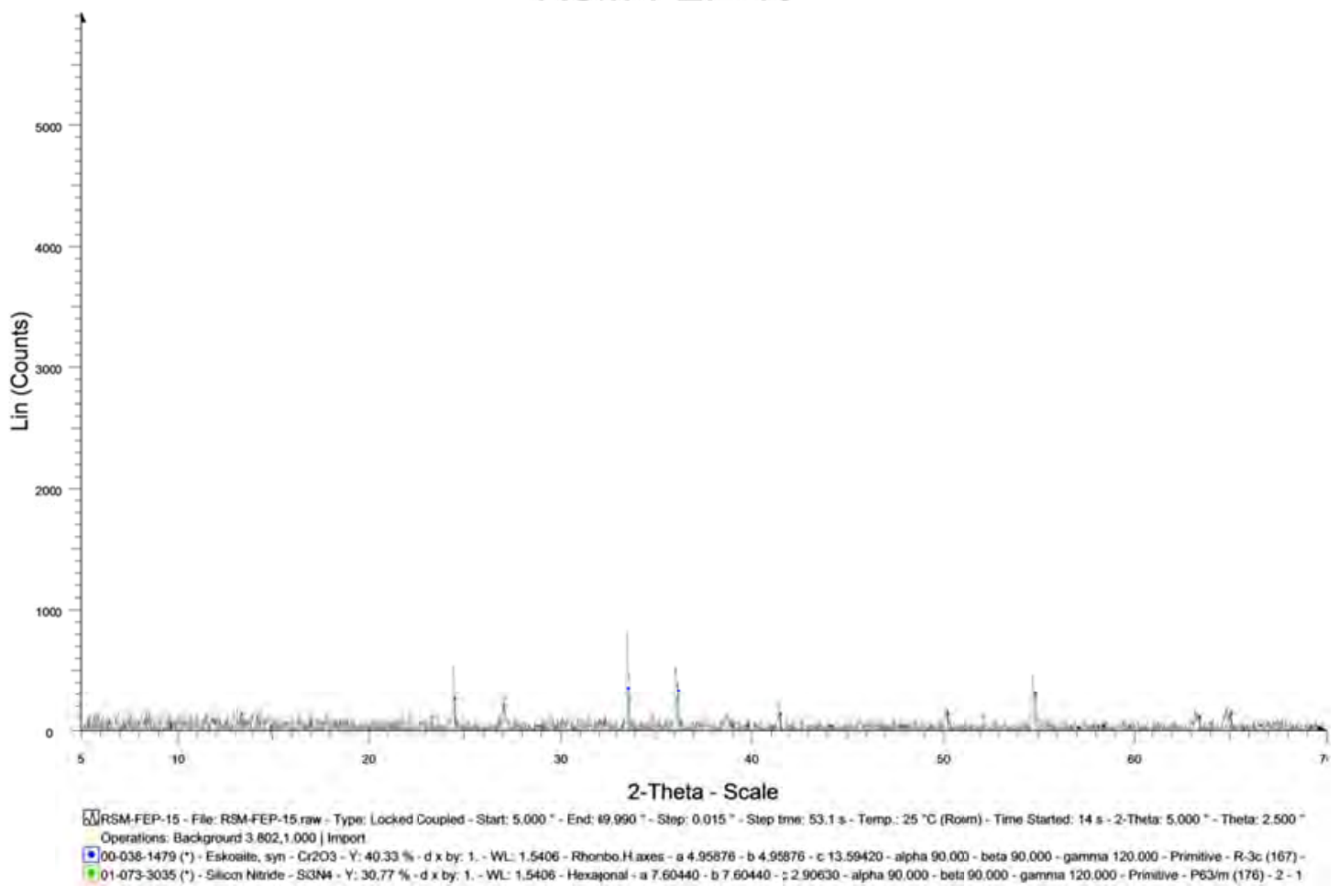




\section{RSM-FEP-34CCC}

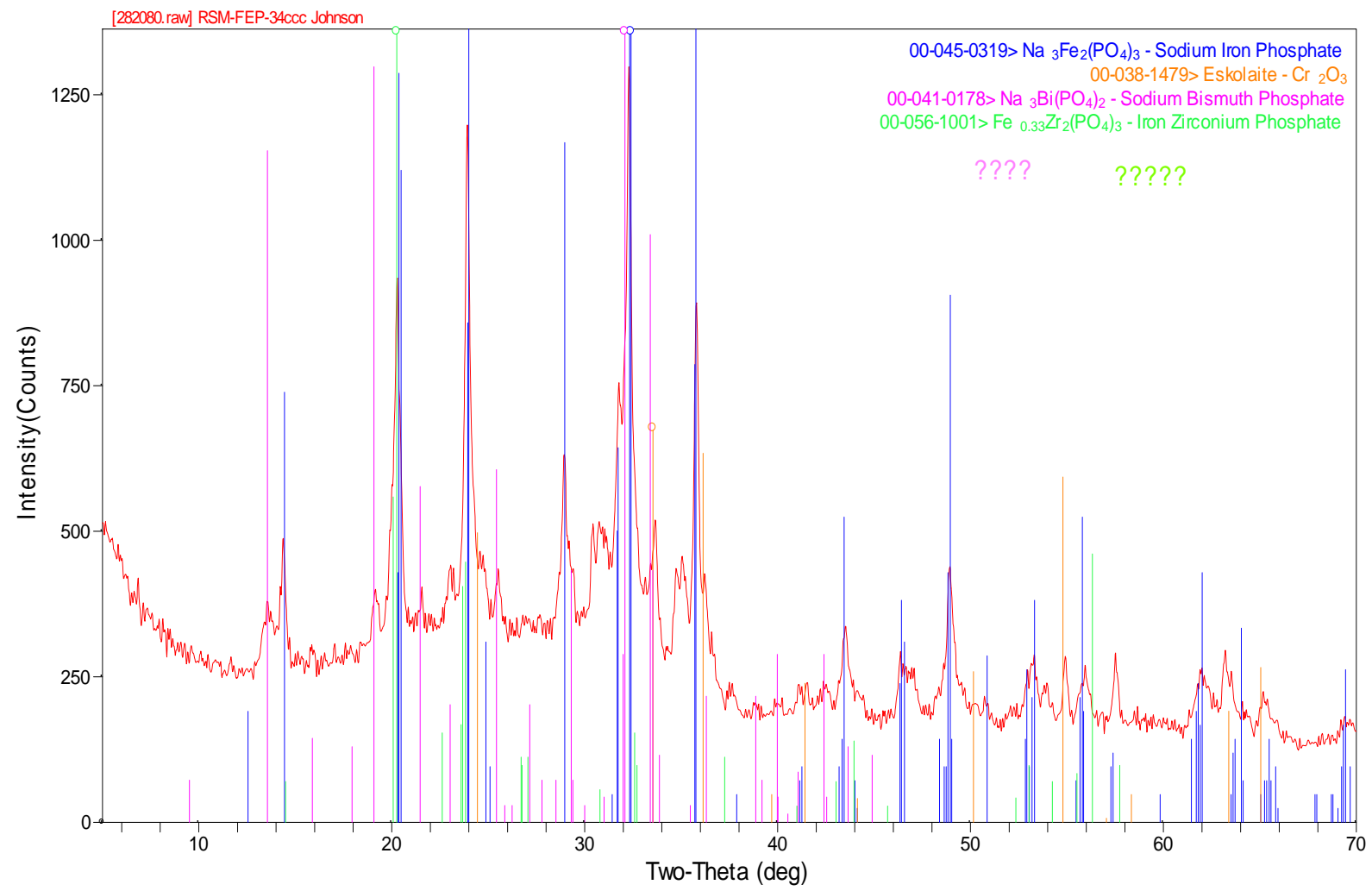

Note: Question marks indicate that the identification of the identified minor phases is questionable. 


\section{RSM-FEP-37}

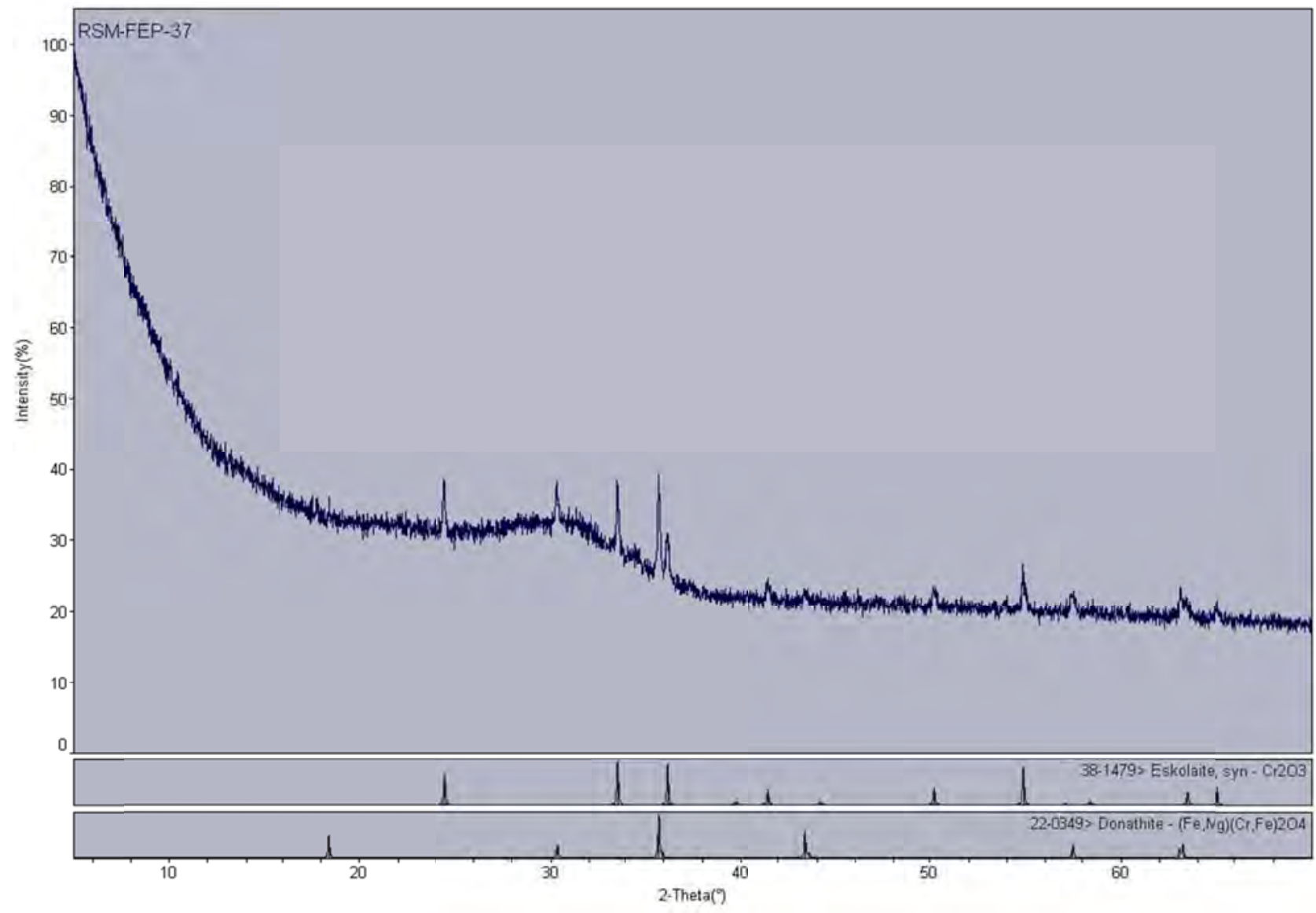




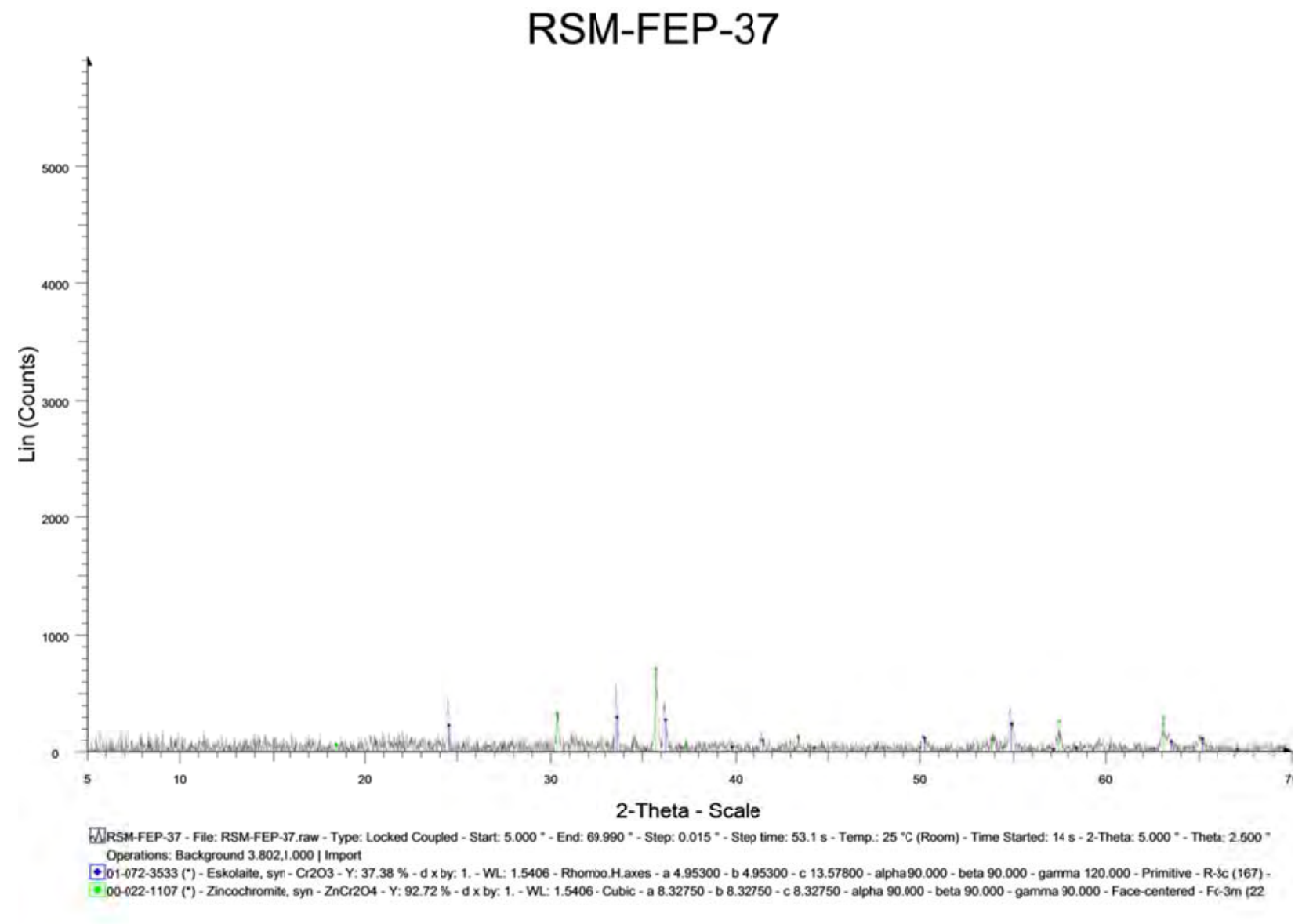




\section{RSM-FEP-46}

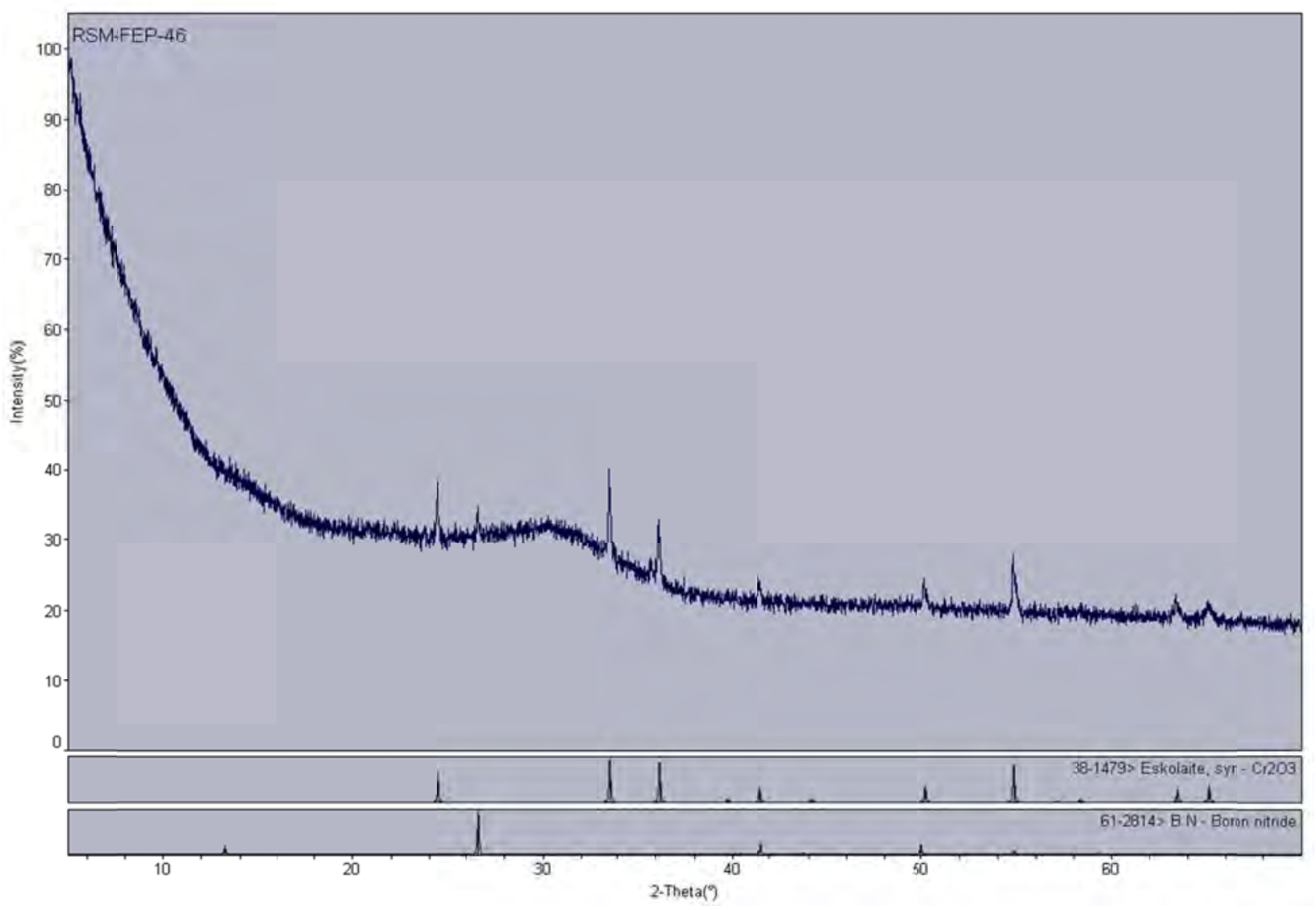




\section{RSM-FEP-46}

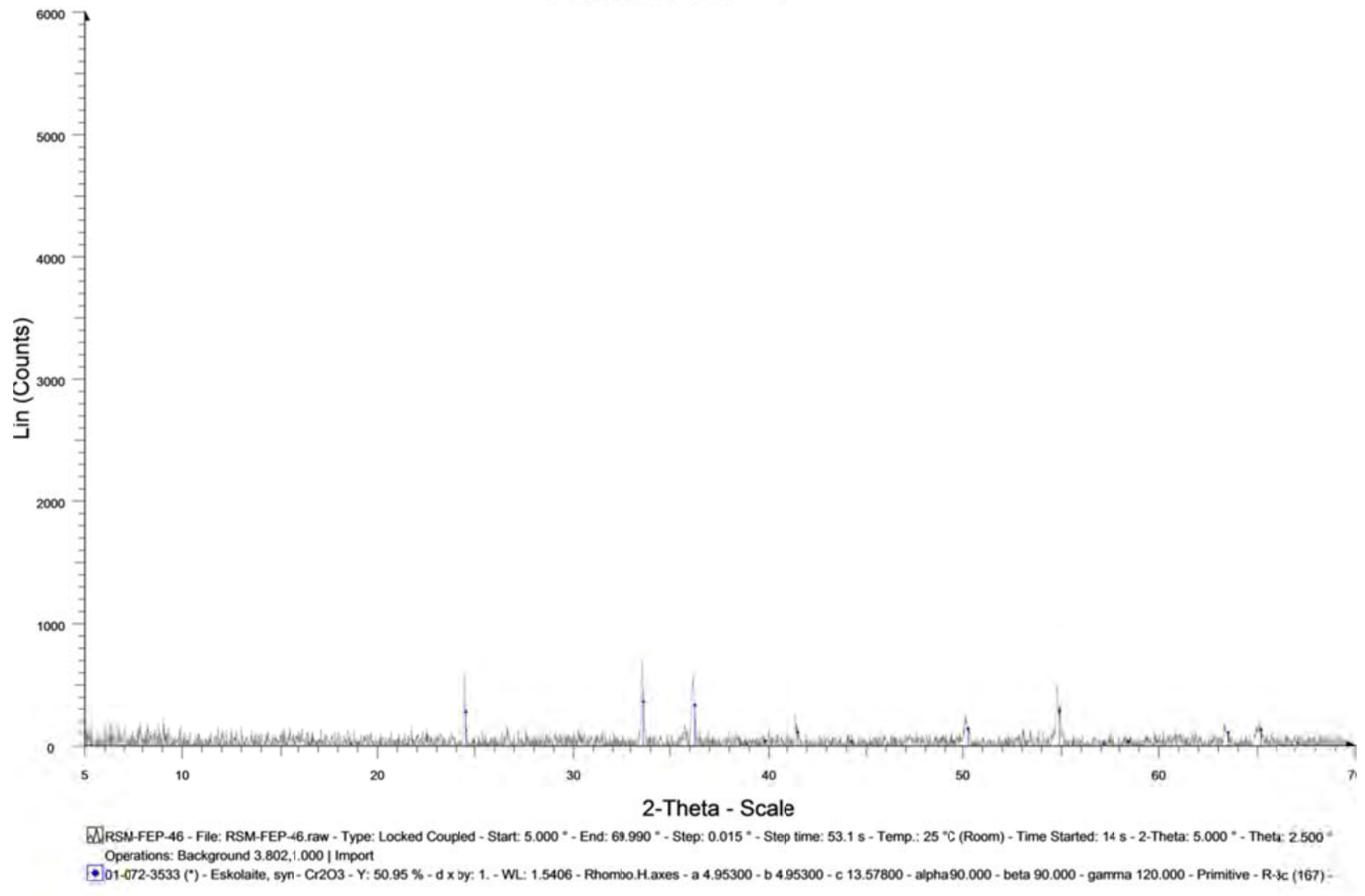

RSM-FEP-59

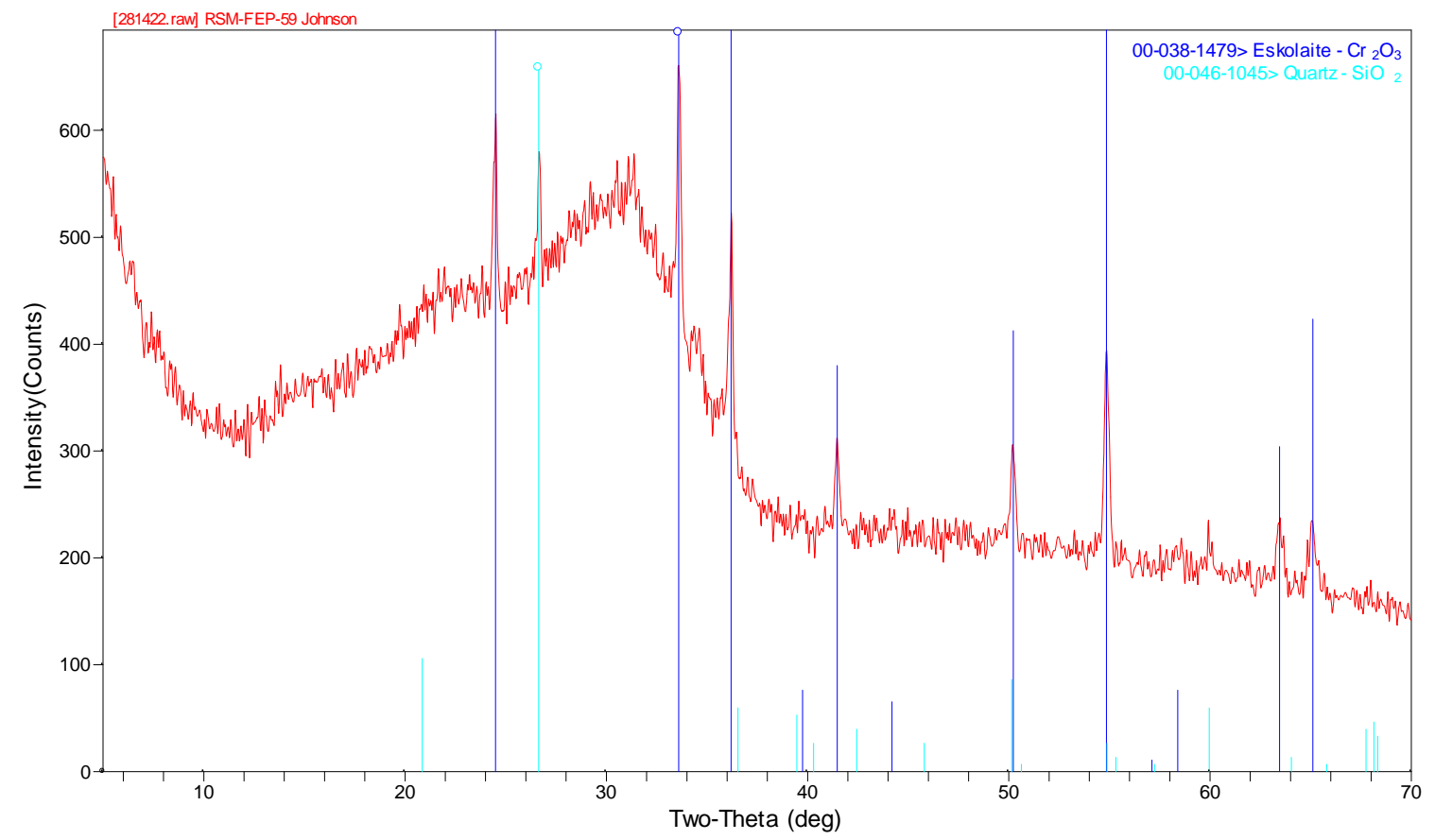




\section{RSM-FEP-59CCC}

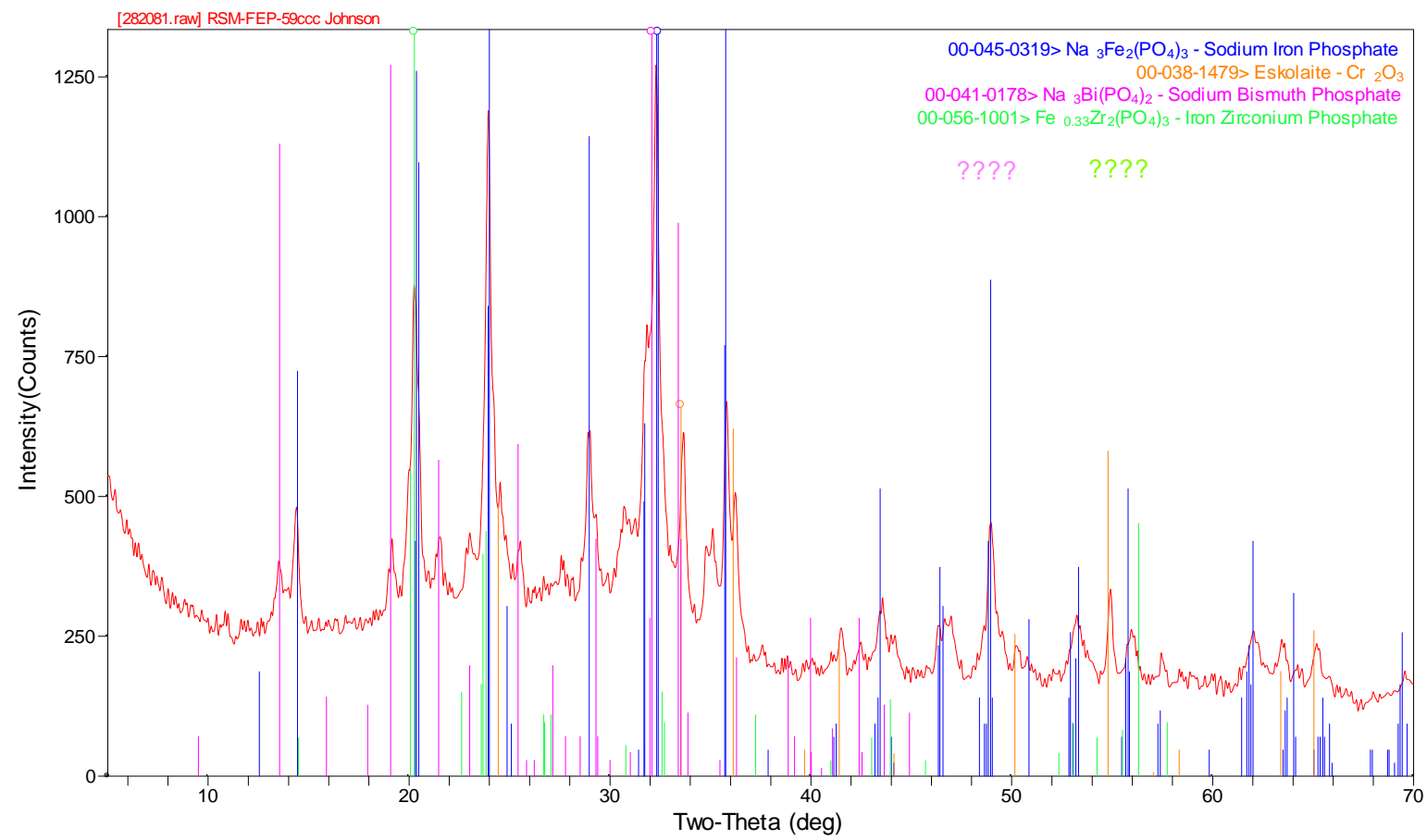

Note: Question marks indicate that the identification of the identified minor phases is questionable.

Analyses of RSM glass by MoSi Corp is provided in the graph below:

Sulfate Retention vs. Iron Redox (RSM FeP Glass)

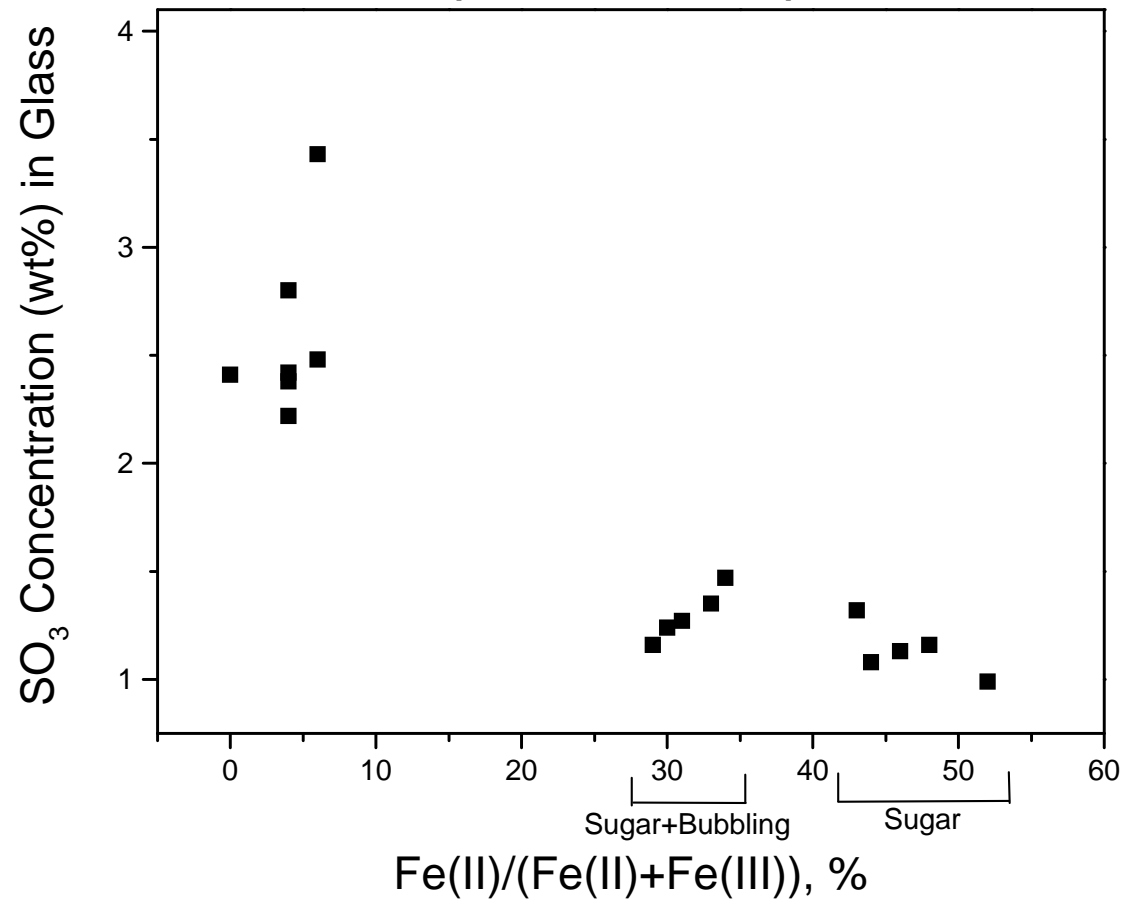





\section{Appendix C}

Research-Scale Melter Measurement and Testing Equipment 



\section{Appendix C}

\section{Research-Scale Melter Measurement and Testing Equipment}

\begin{tabular}{llll}
\hline \multicolumn{1}{c}{ Description } & \multicolumn{1}{c}{ M\&TE Description } & \multicolumn{1}{c}{ Location } & \multicolumn{1}{c}{ Calibration } \\
Level
\end{tabular}





\section{Appendix D}

\section{Operating Parameters Data Plots from RSM Test}





\section{Appendix D}

\section{Operating Parameters Data Plots from RSM Test}

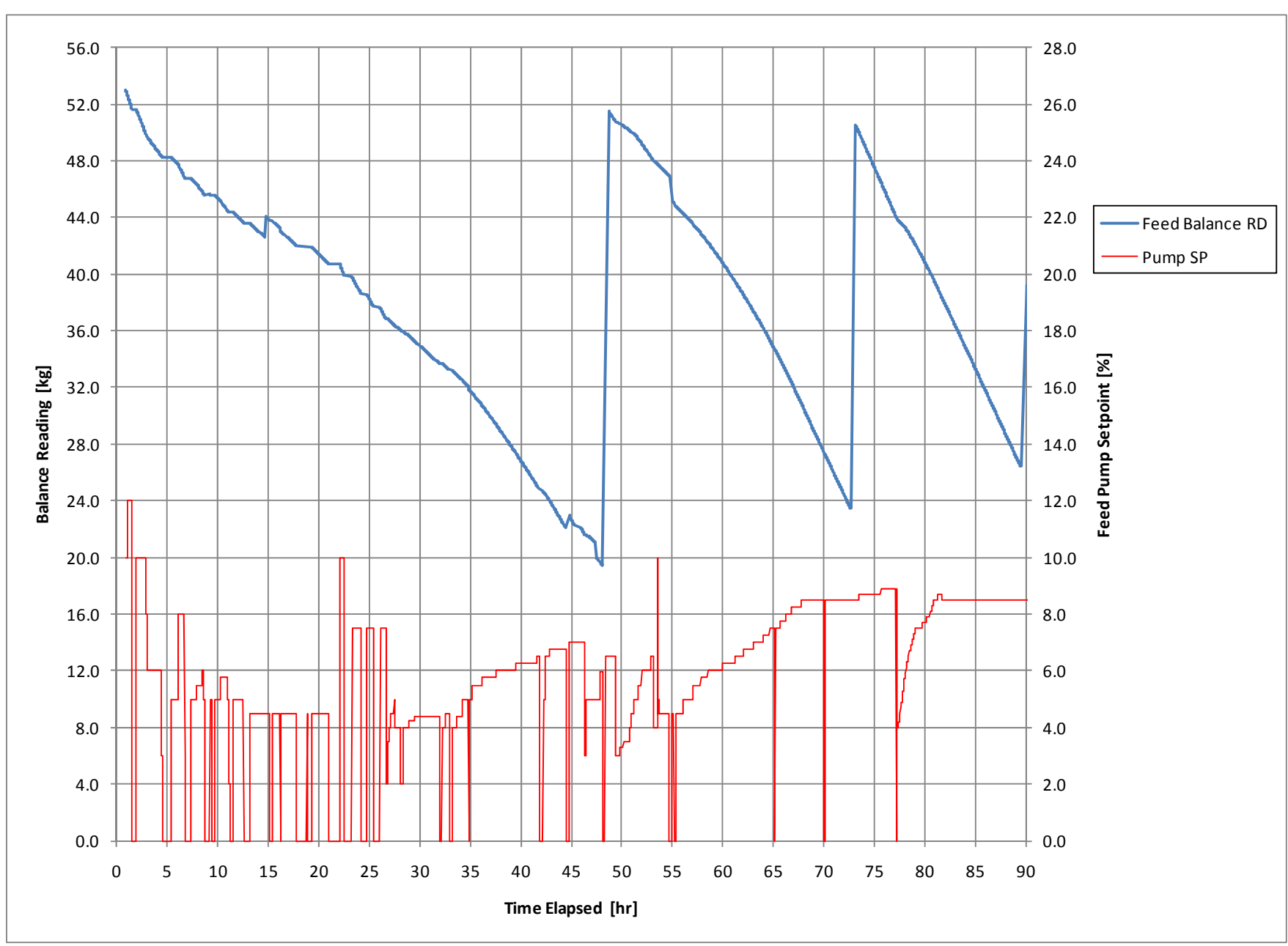

Figure D.1. Simulant Feed Pump Setpoint and Balance Reading (0-90 hours) 


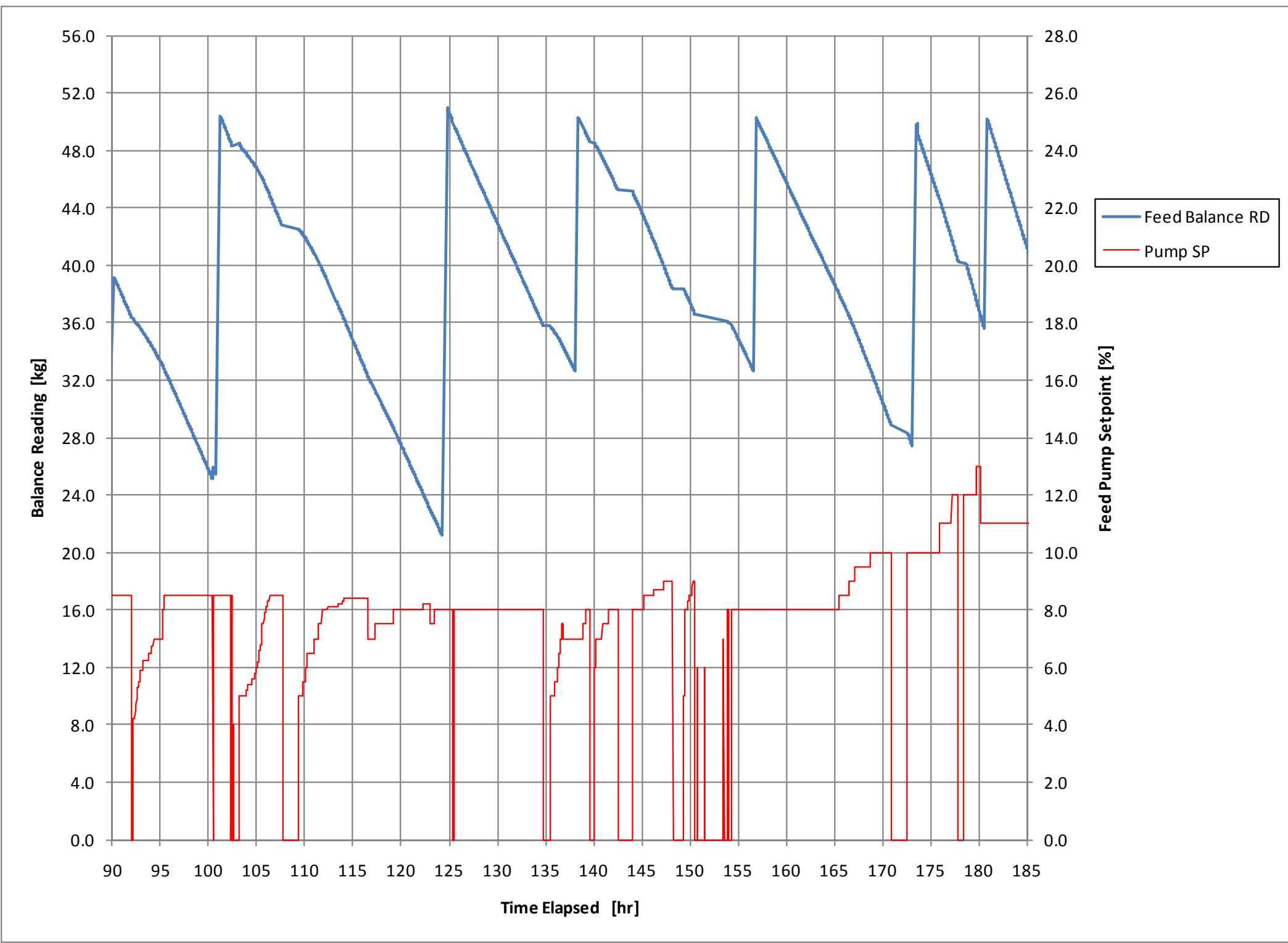

Figure D.2. Simulant Feed Pump Setpoint and Balance Reading (90-185 hours) 


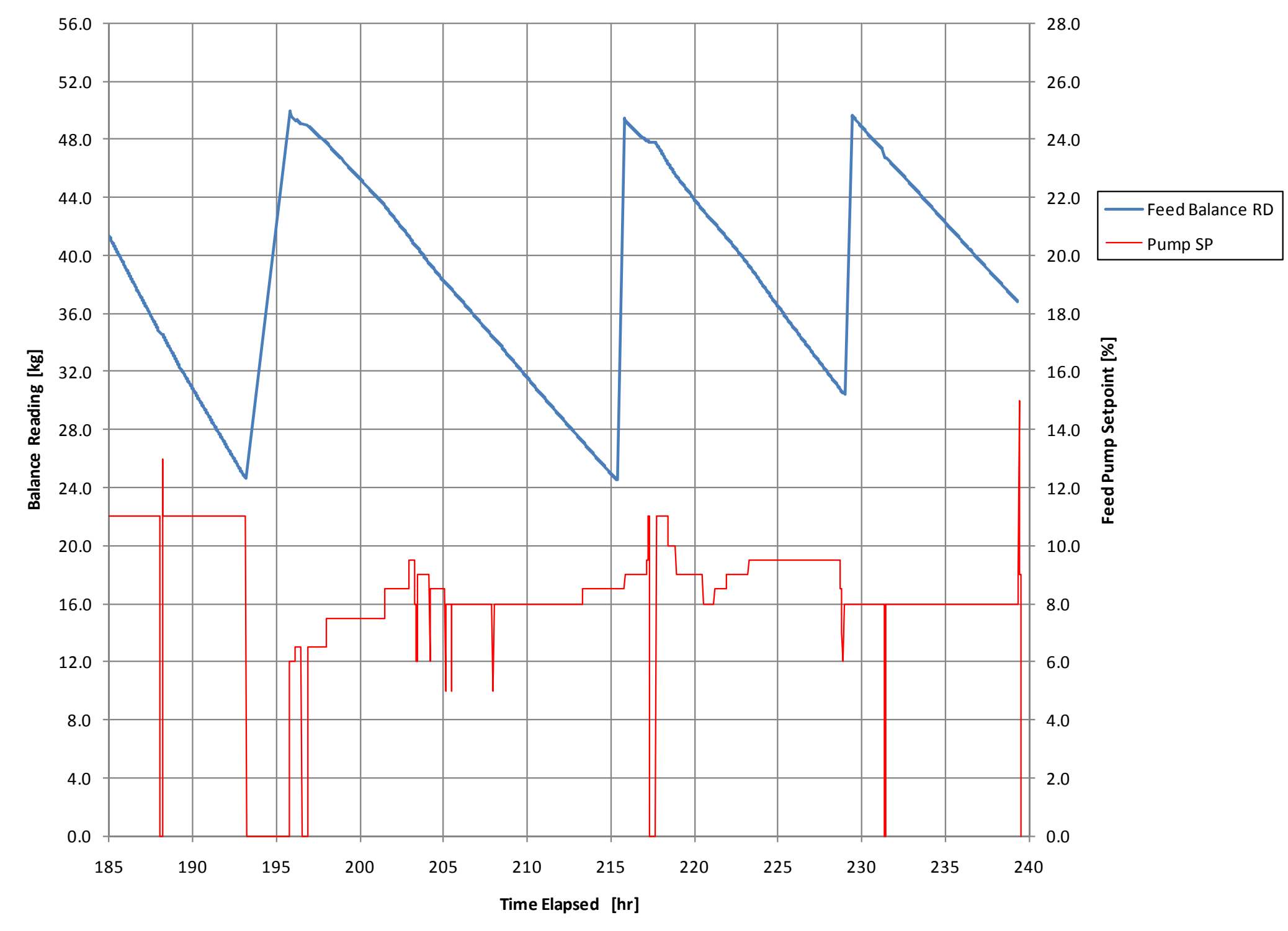

Figure D.3. Simulant Feed Pump Setpoint and Balance Reading (185 hours-end of test) 


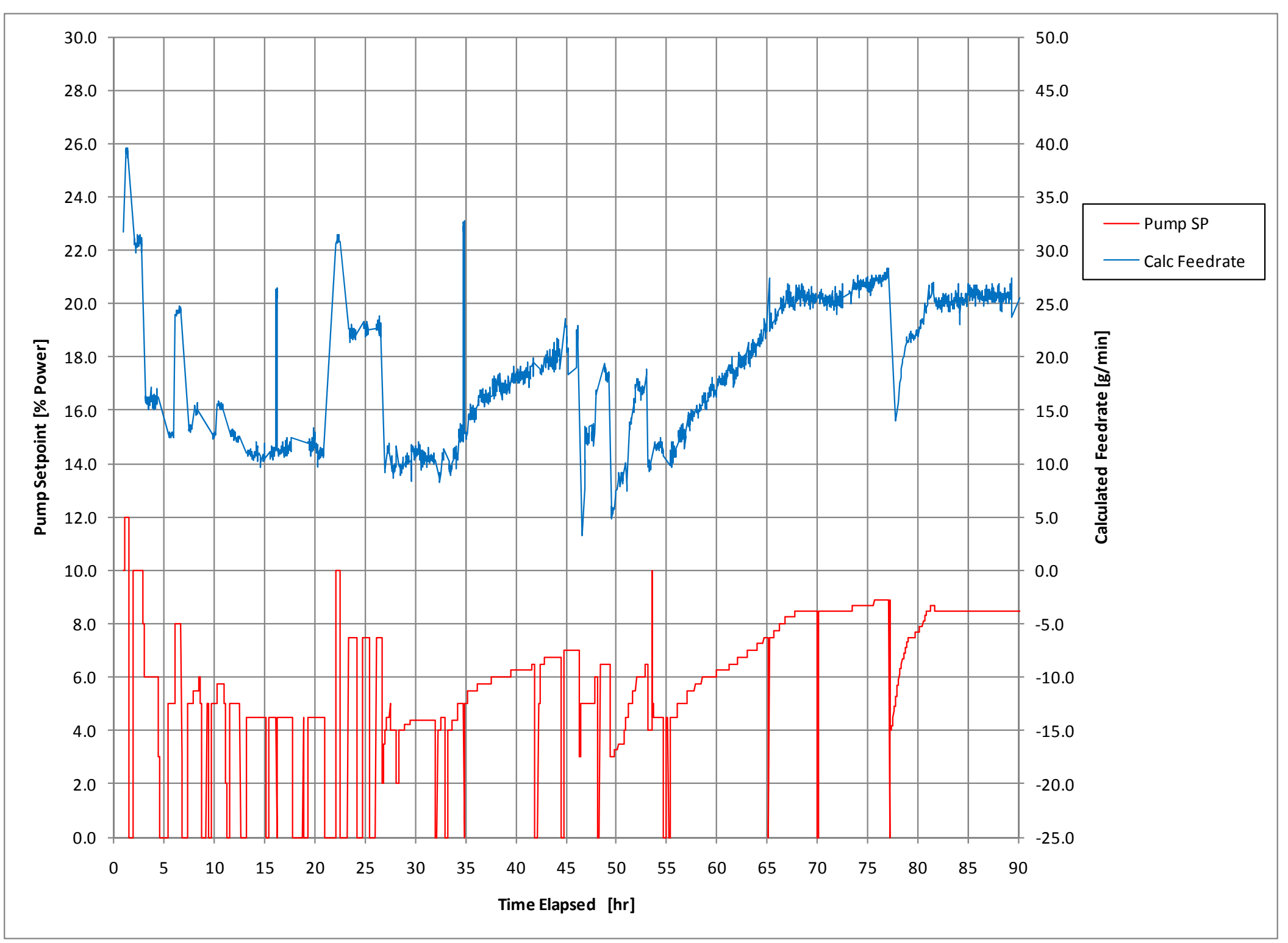

Figure D.4. Simulant Feed Pump Setpoint and Calculated Feed Rate (0-90 hours) 


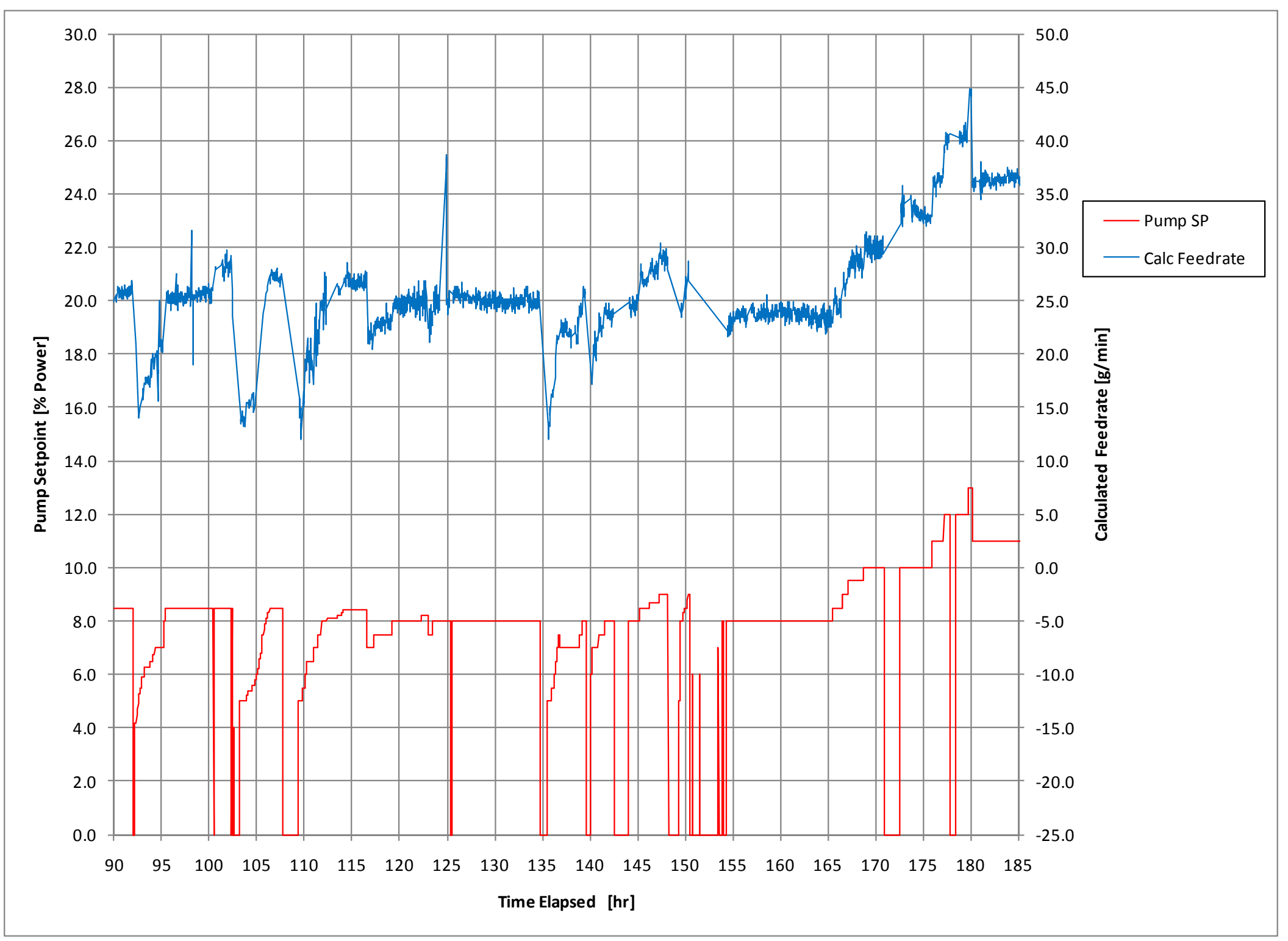

Figure D.5. Simulant Feed Pump Setpoint and Calculated Feed Rate (90-185 hours) 


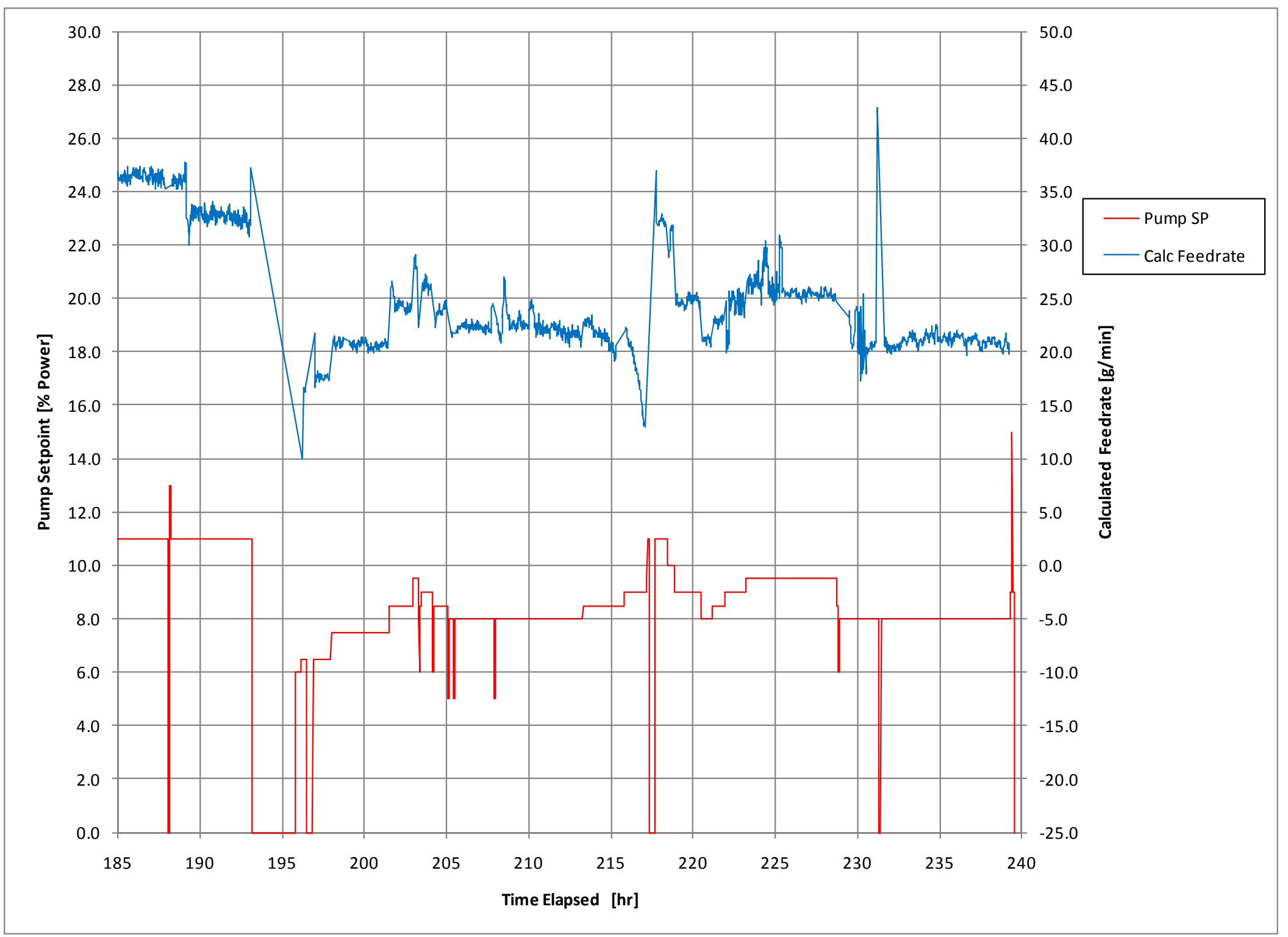

Figure D.6. Simulant Feed Pump Setpoint and Calculated Feed Rate (185 hours-end of test) 


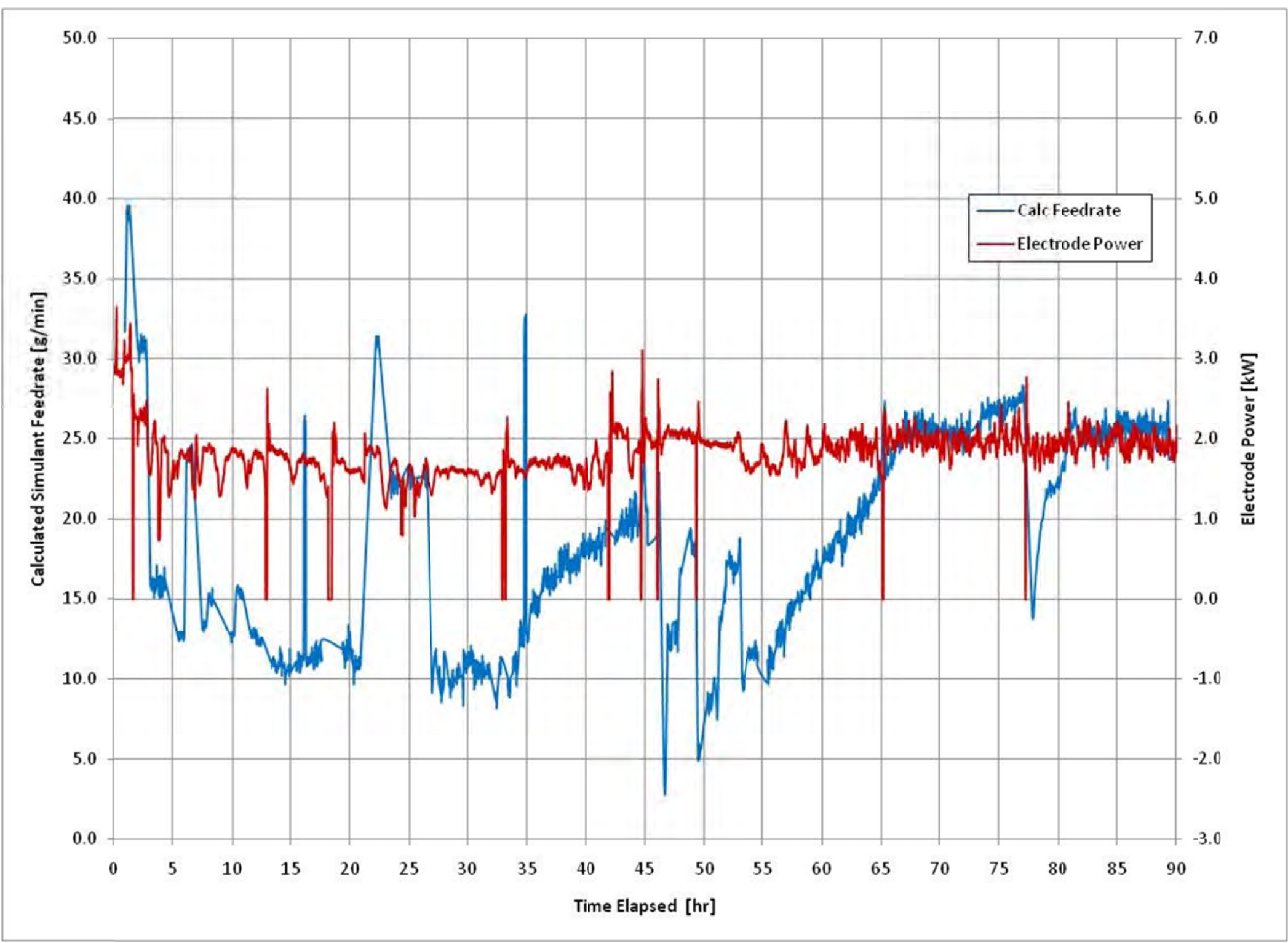

Figure D.7. Calculated Simulant Feed Rate and Electrode Power (0-90 hours) 


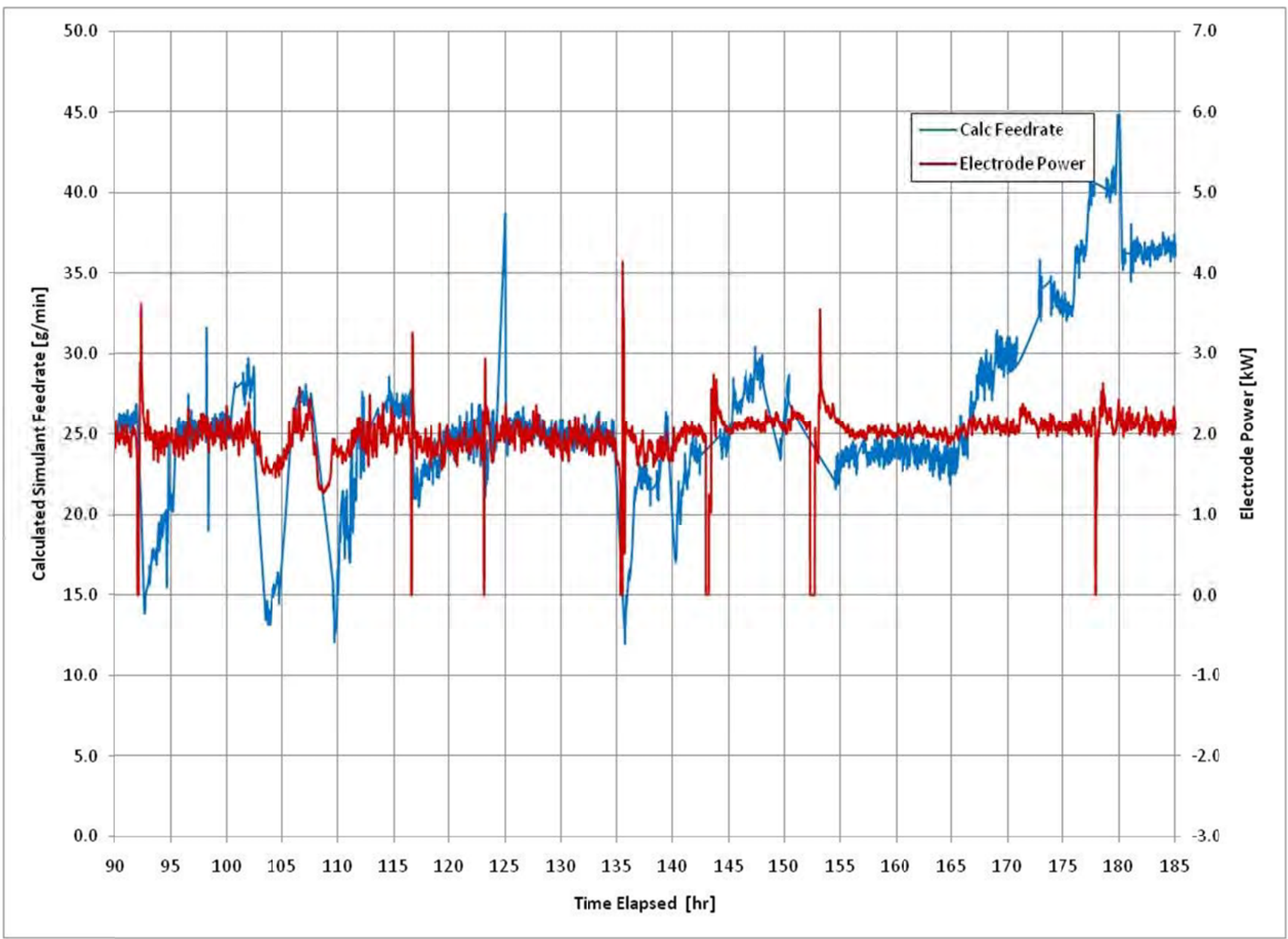

Figure D.8. Calculated Simulant Feed Rate and Electrode Power (90-185 hours) 


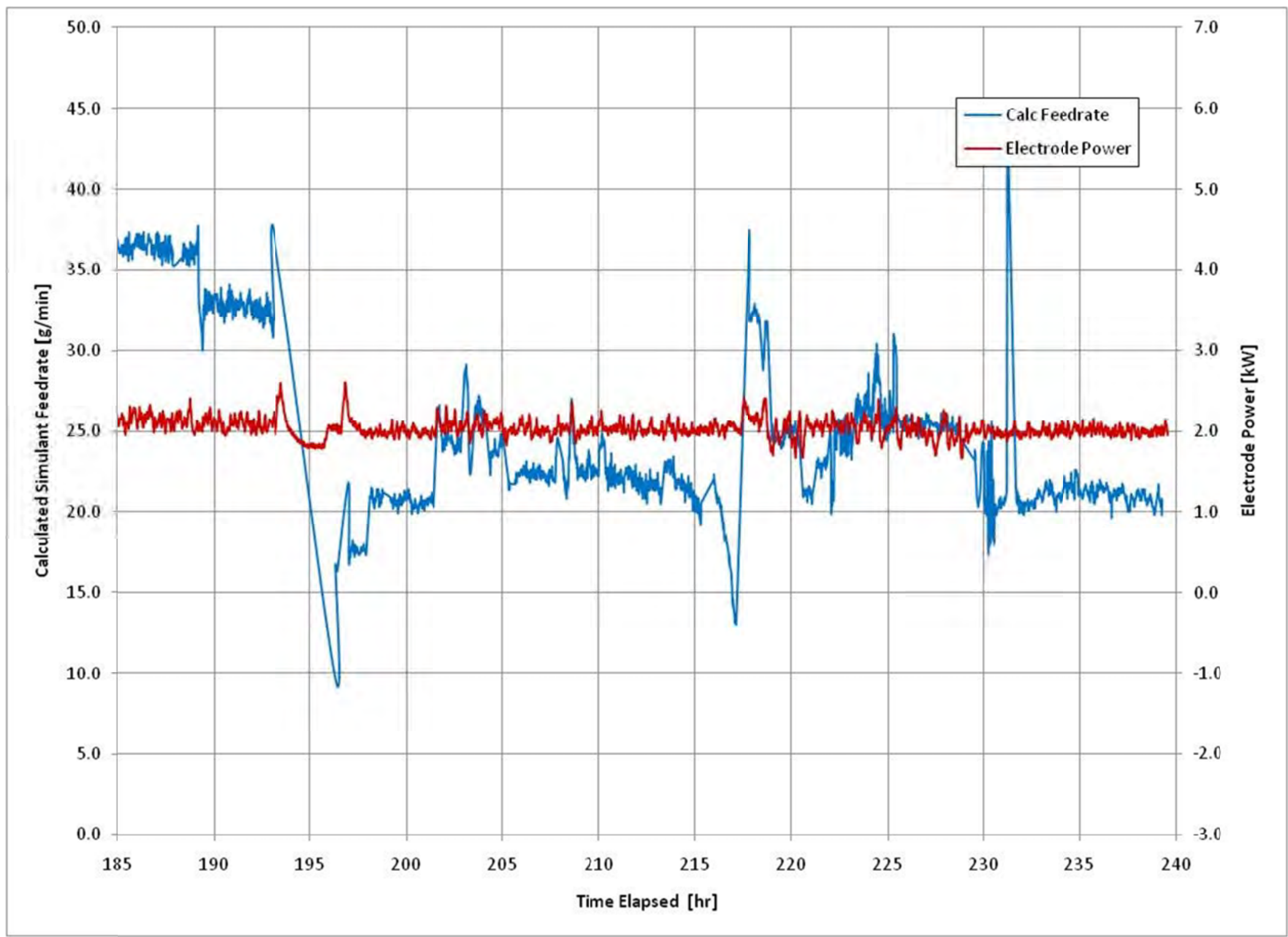

Figure D.9. Calculated Simulant Feed Rate and Electrode Power (185 hours-end of test) 


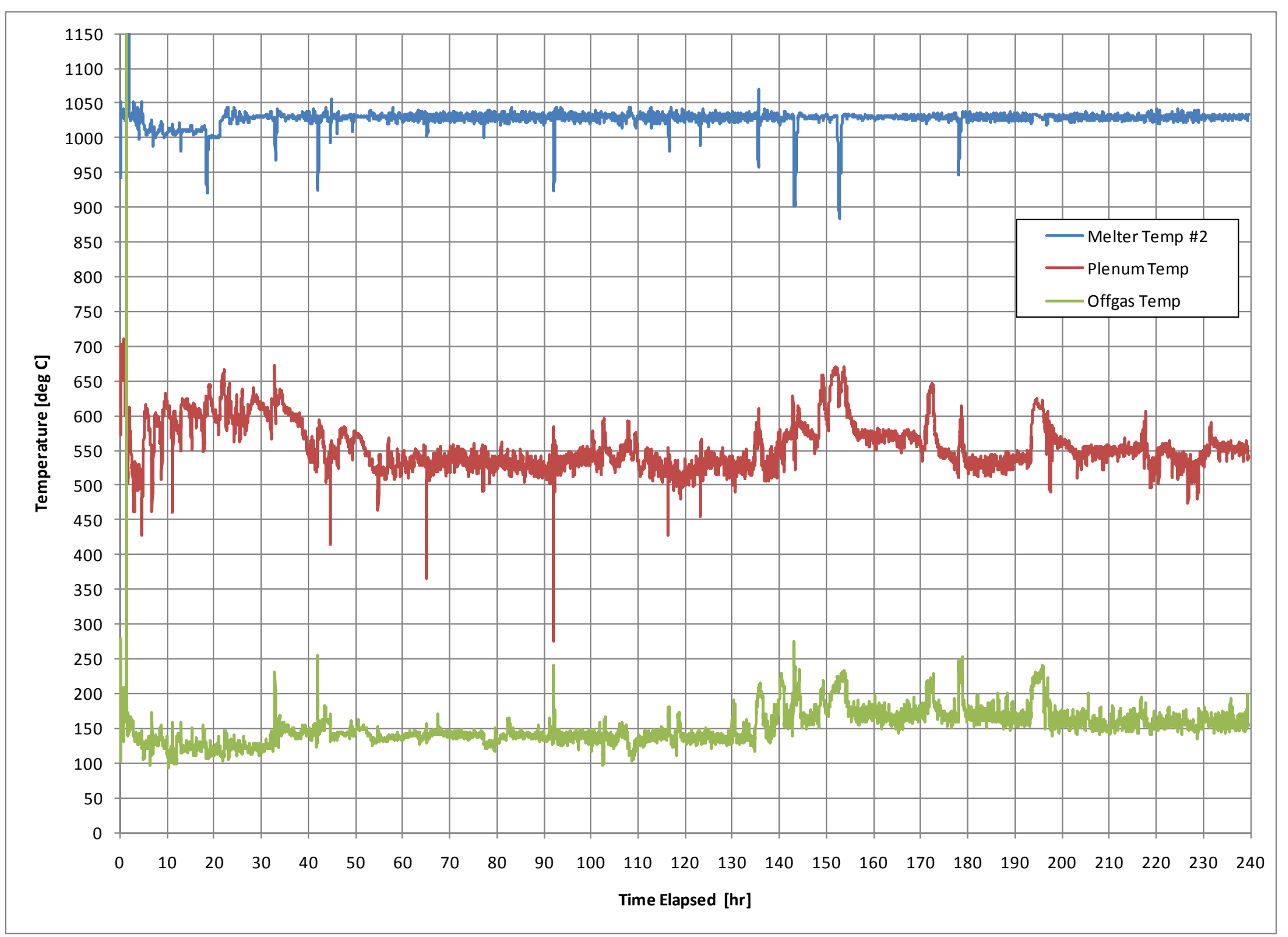

Figure D.10. Melter, Plenum, and Offgas Temperatures 


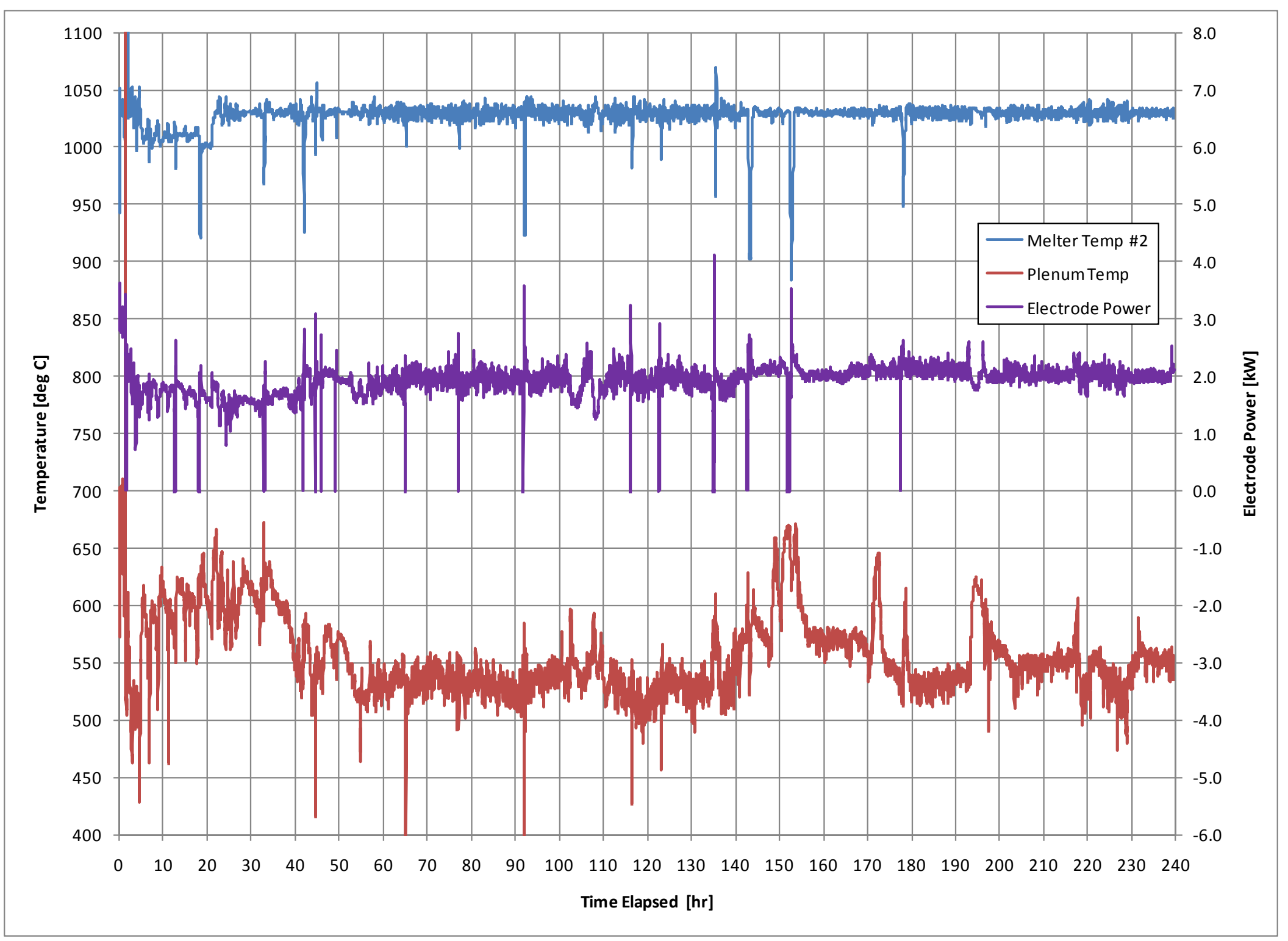

Figure D.11. Melter/Plenum Temperatures and Electrode Power 


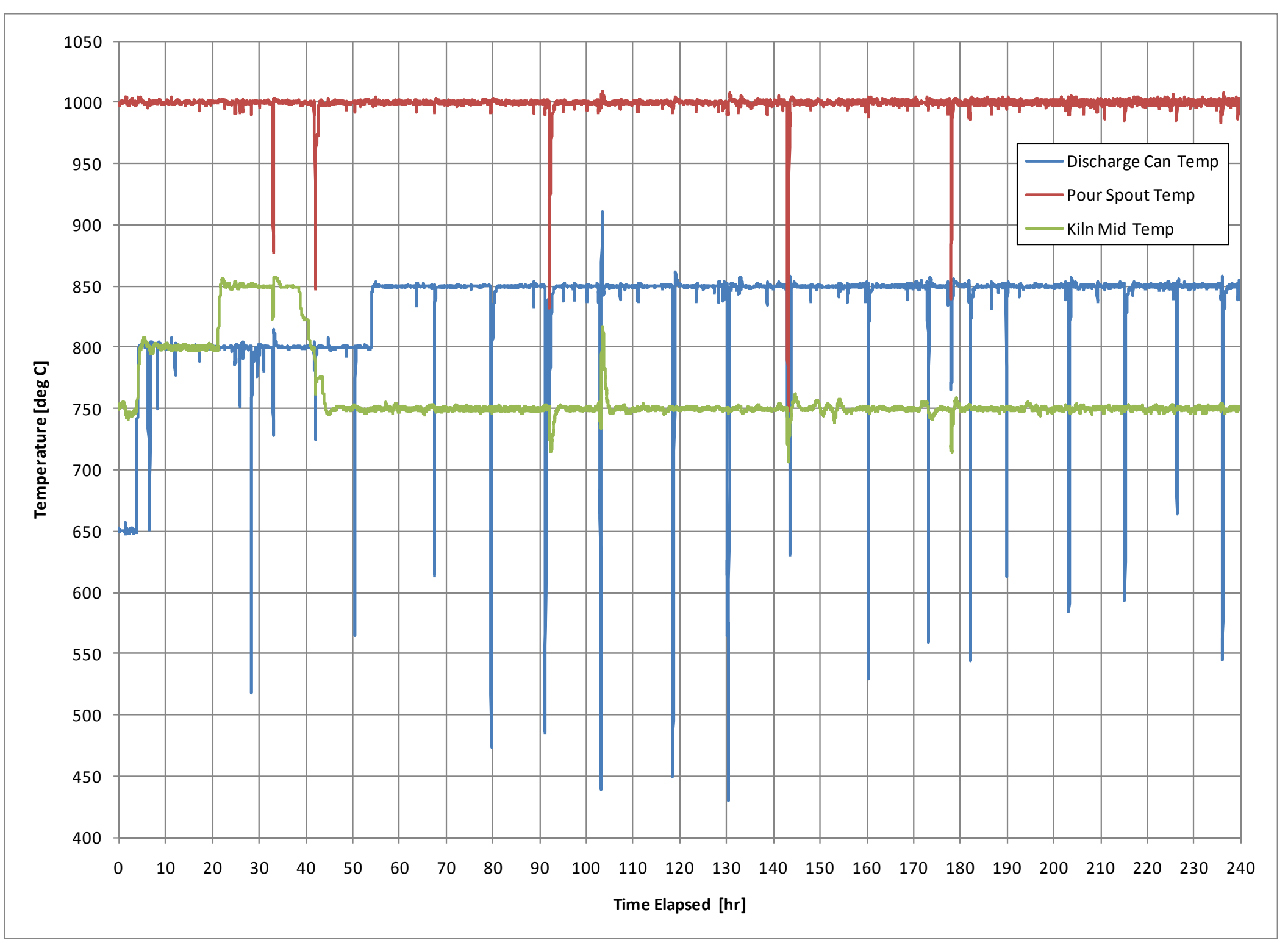

Figure D.12. Discharge Can, Pour Spout, and Kiln (Mid) Temperatures 


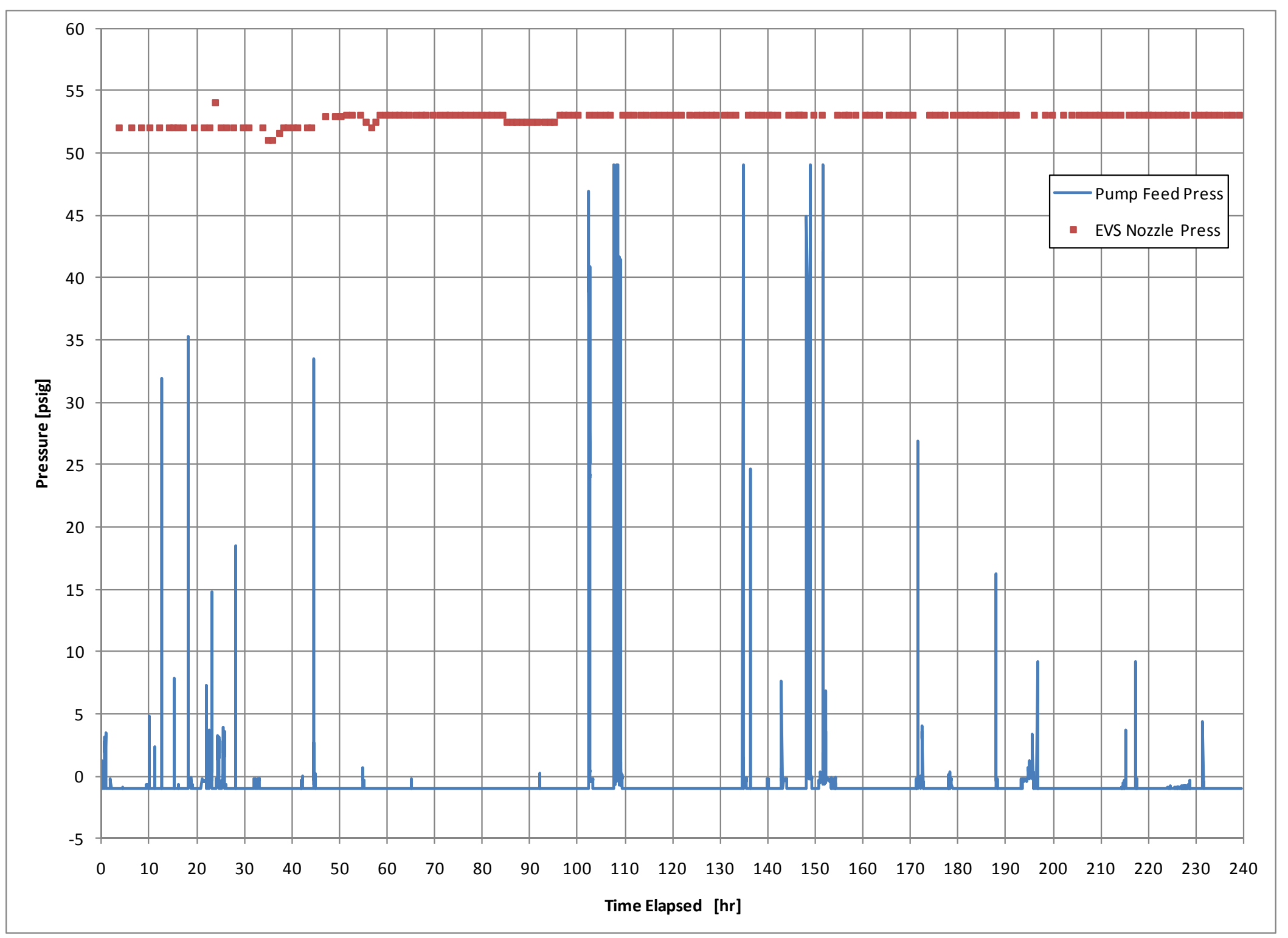

Figure D.13. Feed Pump and EVS Nozzle Pressure 


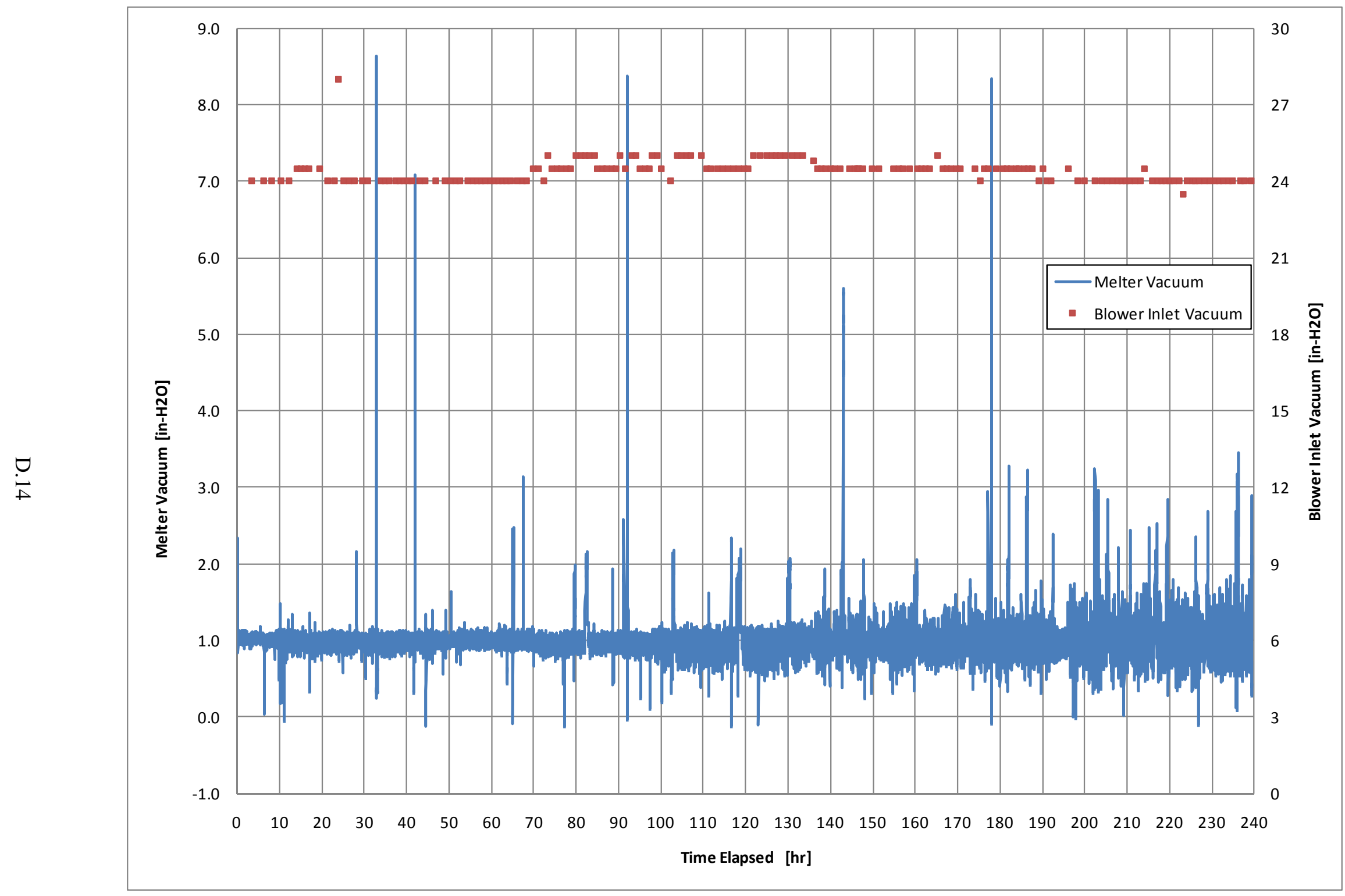

Figure D.14. Blower and Melter Vacuum 


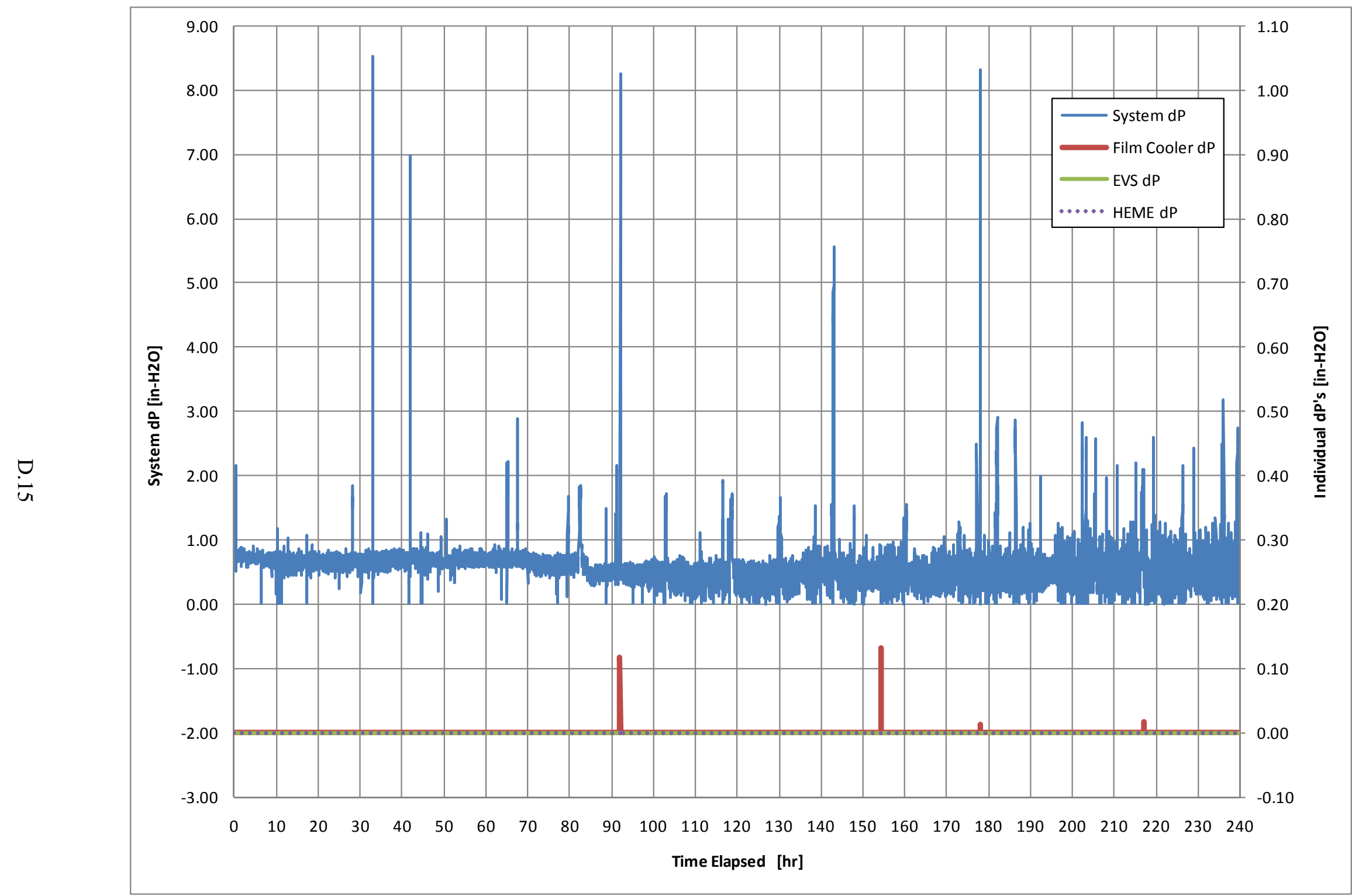

Figure D.15. System, Film Cooler, EVS, and HEME Pressure Drop 


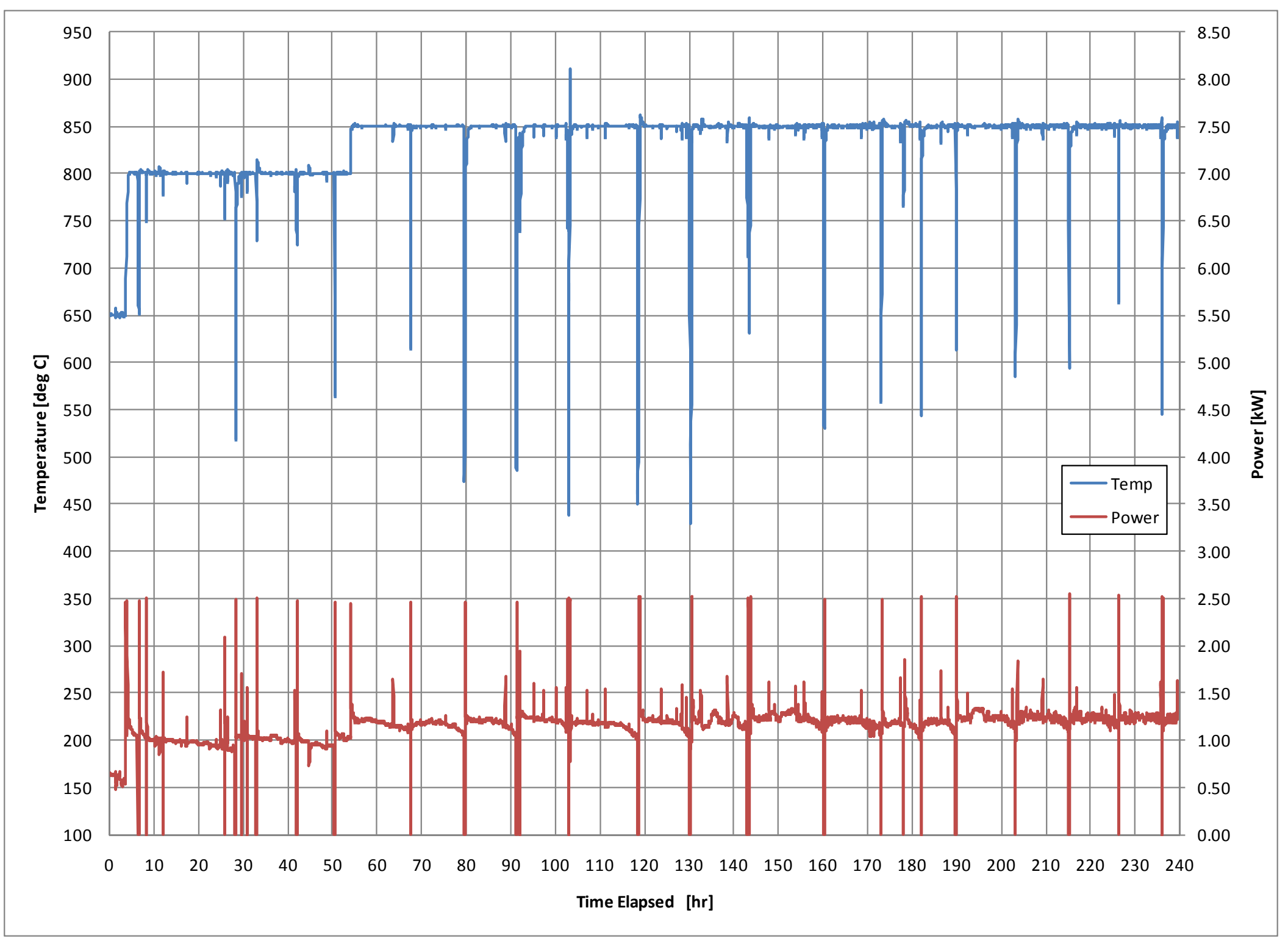

Figure D.16. Discharge Canister Power and Temperature 


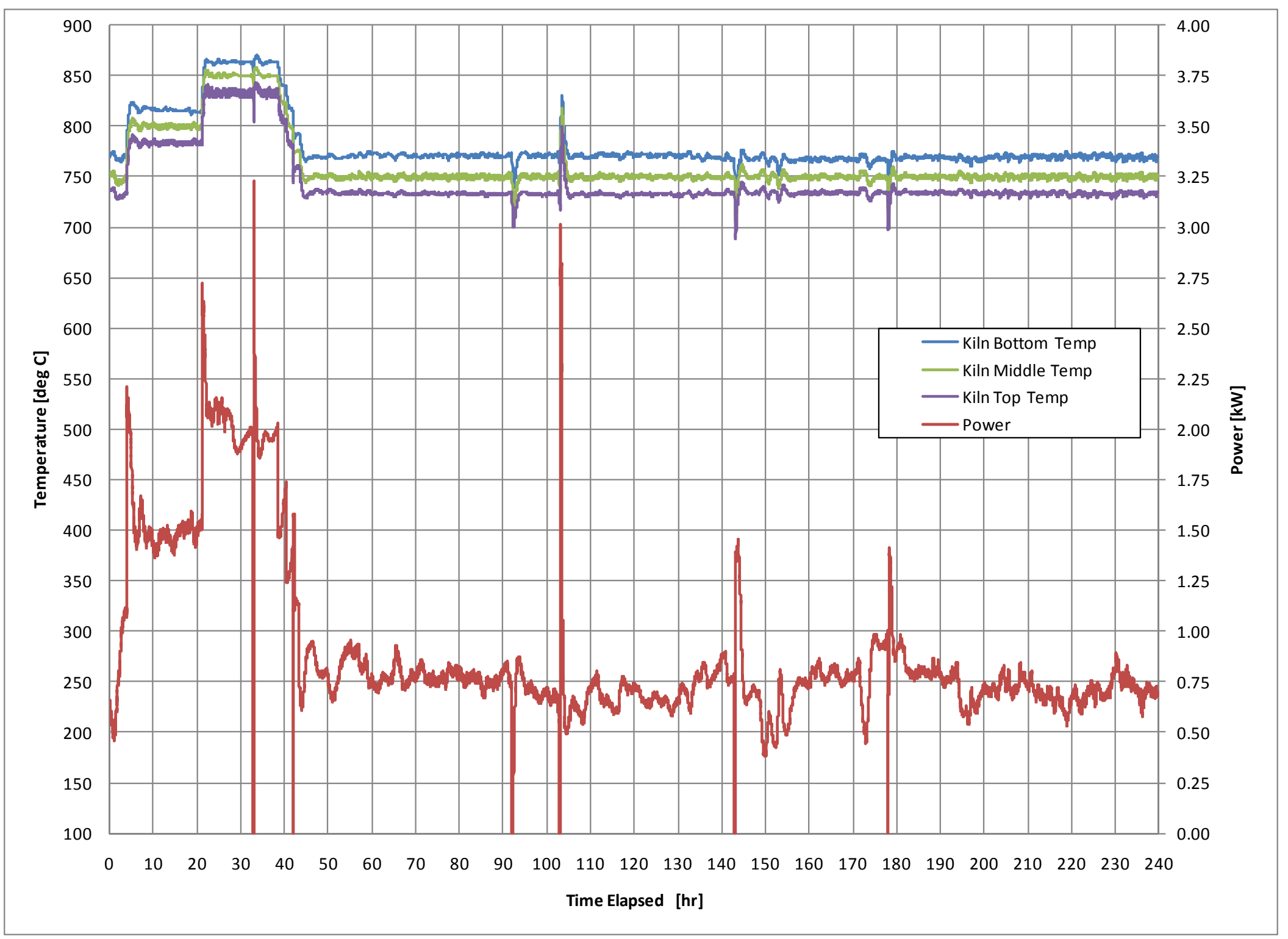

Figure D.17. Kiln Power and Temperature 


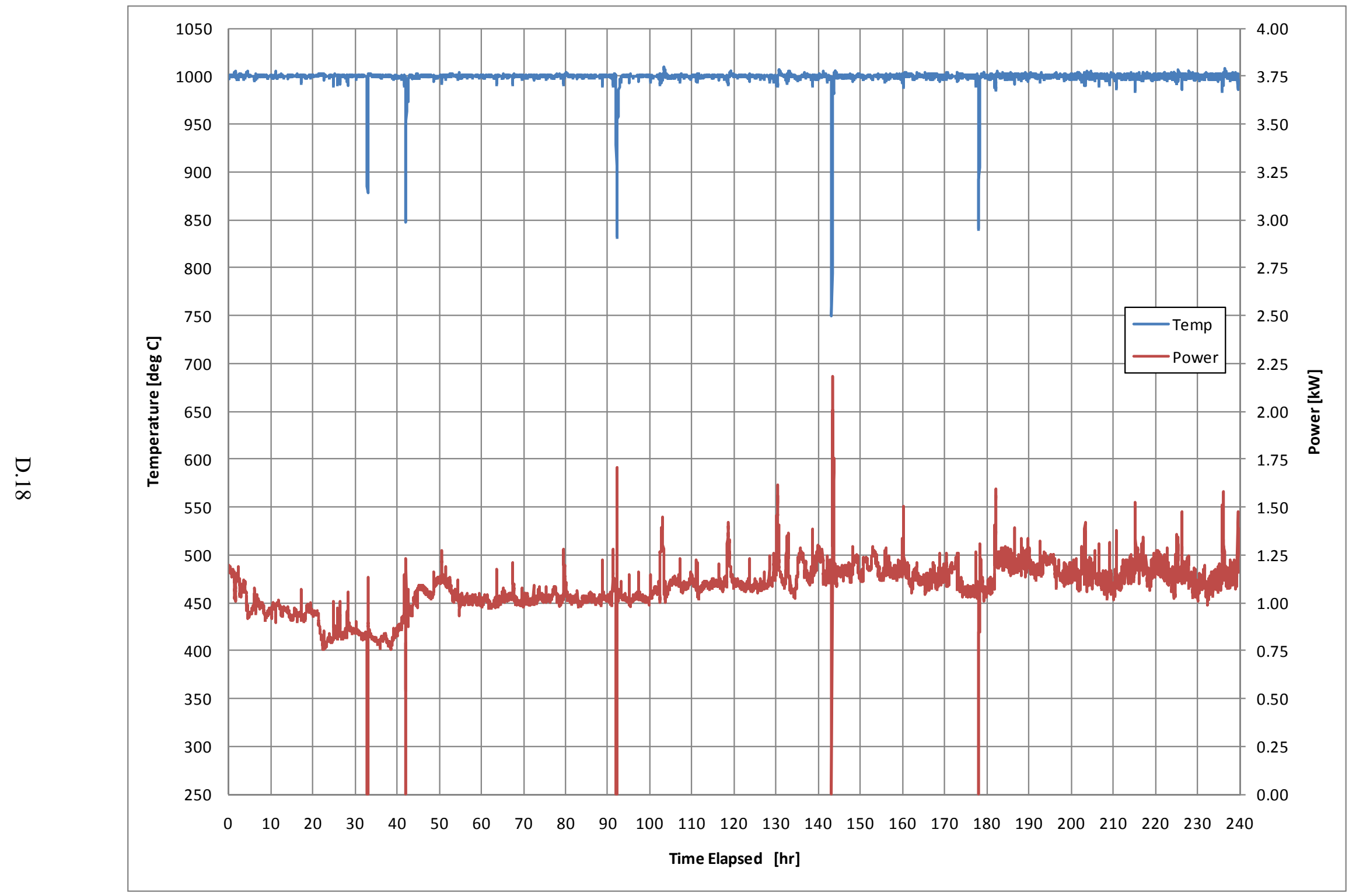

Figure D.18. Pour Spout Power and Temperature 


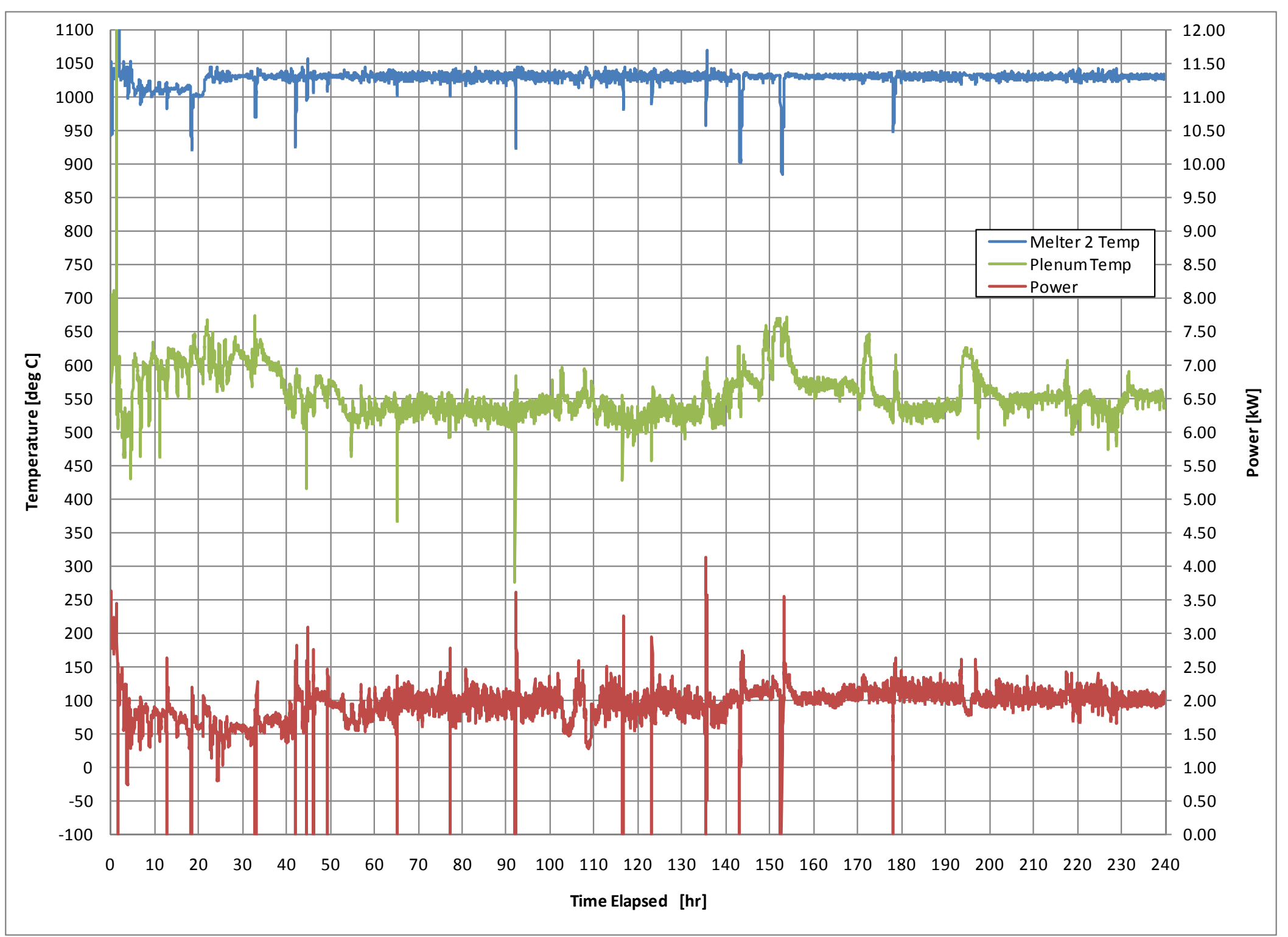

Figure D.19. Melter Electrode Power and Temperature (plenum temperature included) 


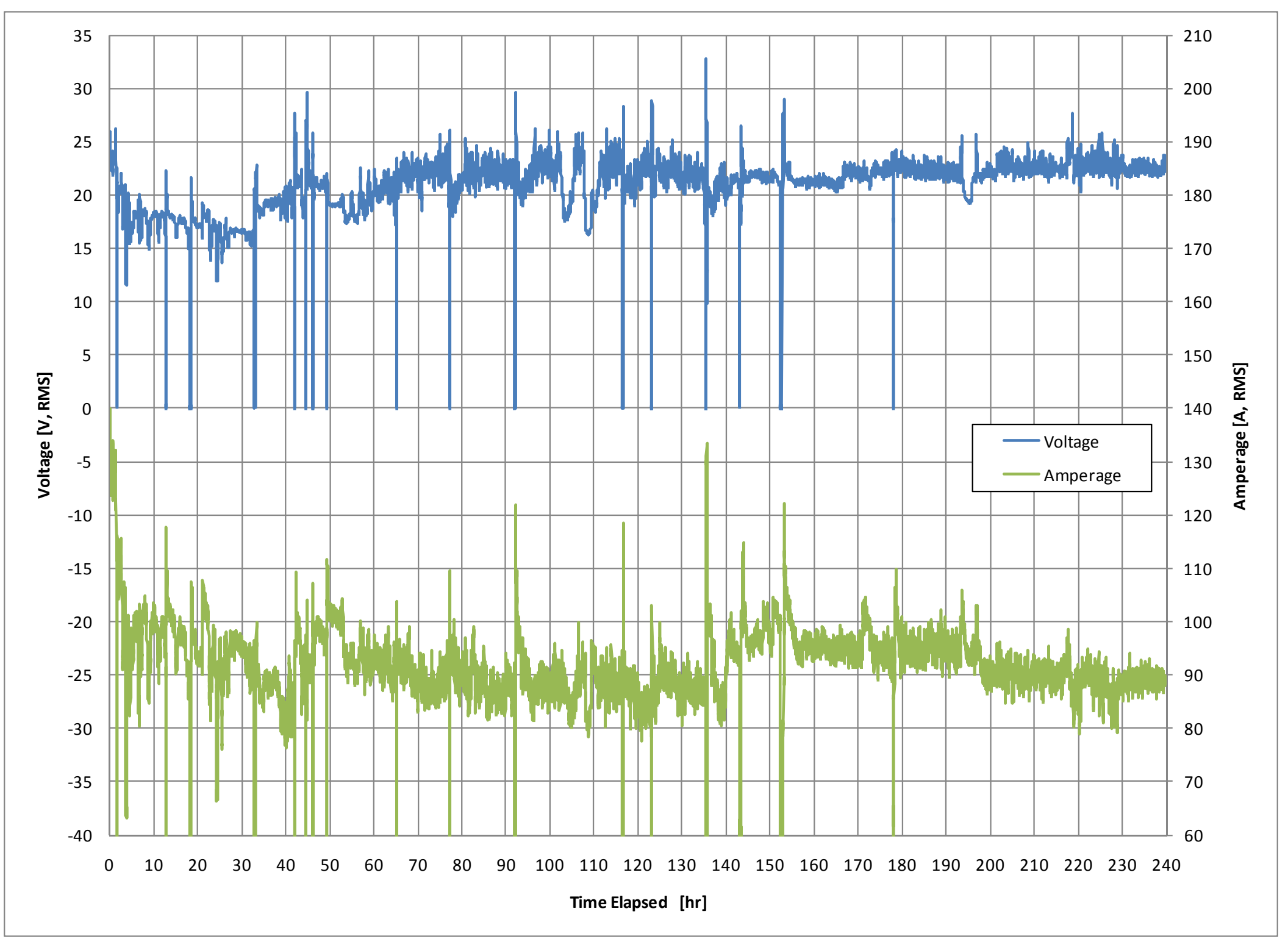

Figure D.20. Melter Electrode Voltage and Amperage 


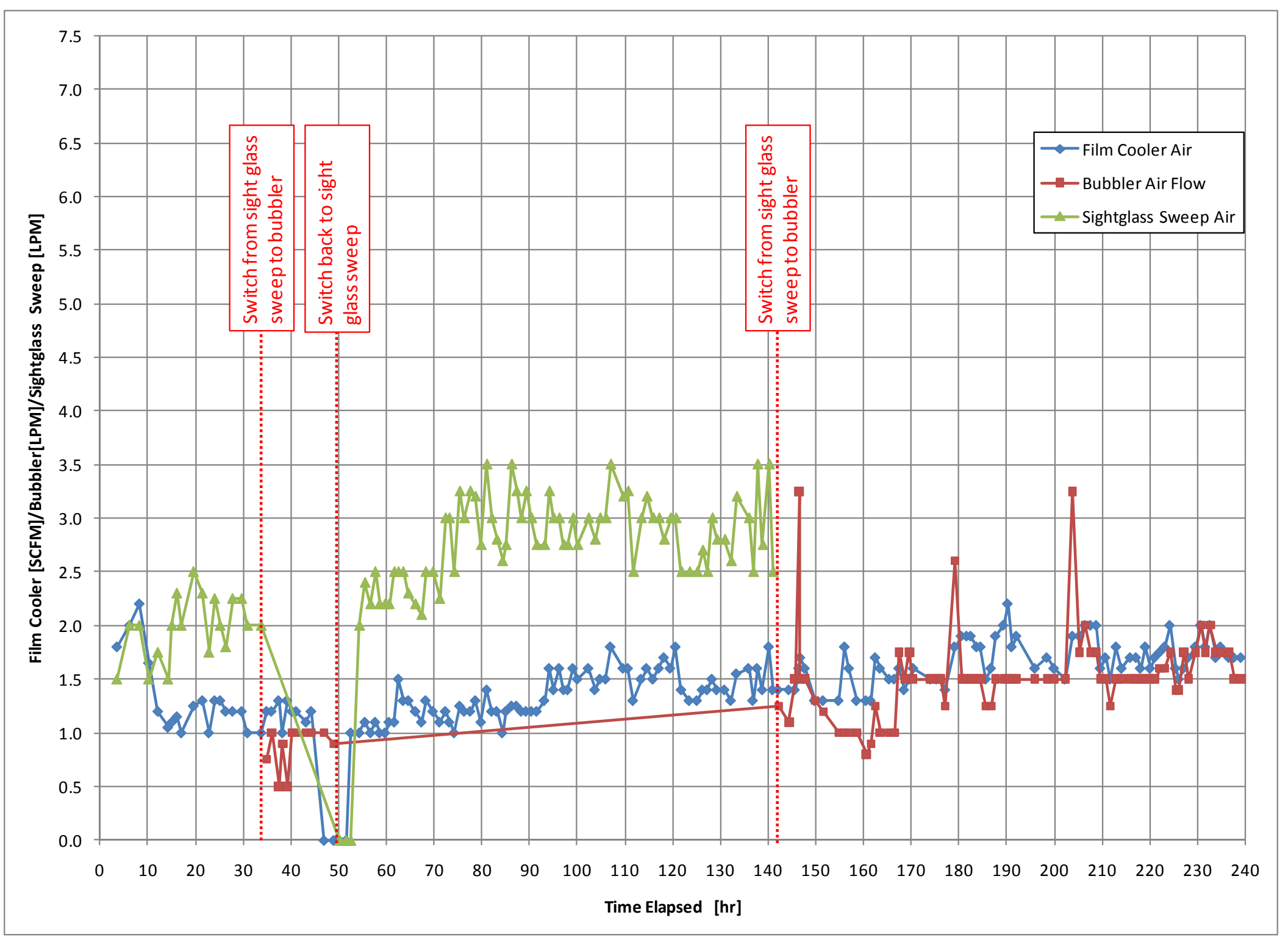

Figure D.21. Film Cooler, Bubbler, and Sight Glass Sweep Flowrates 


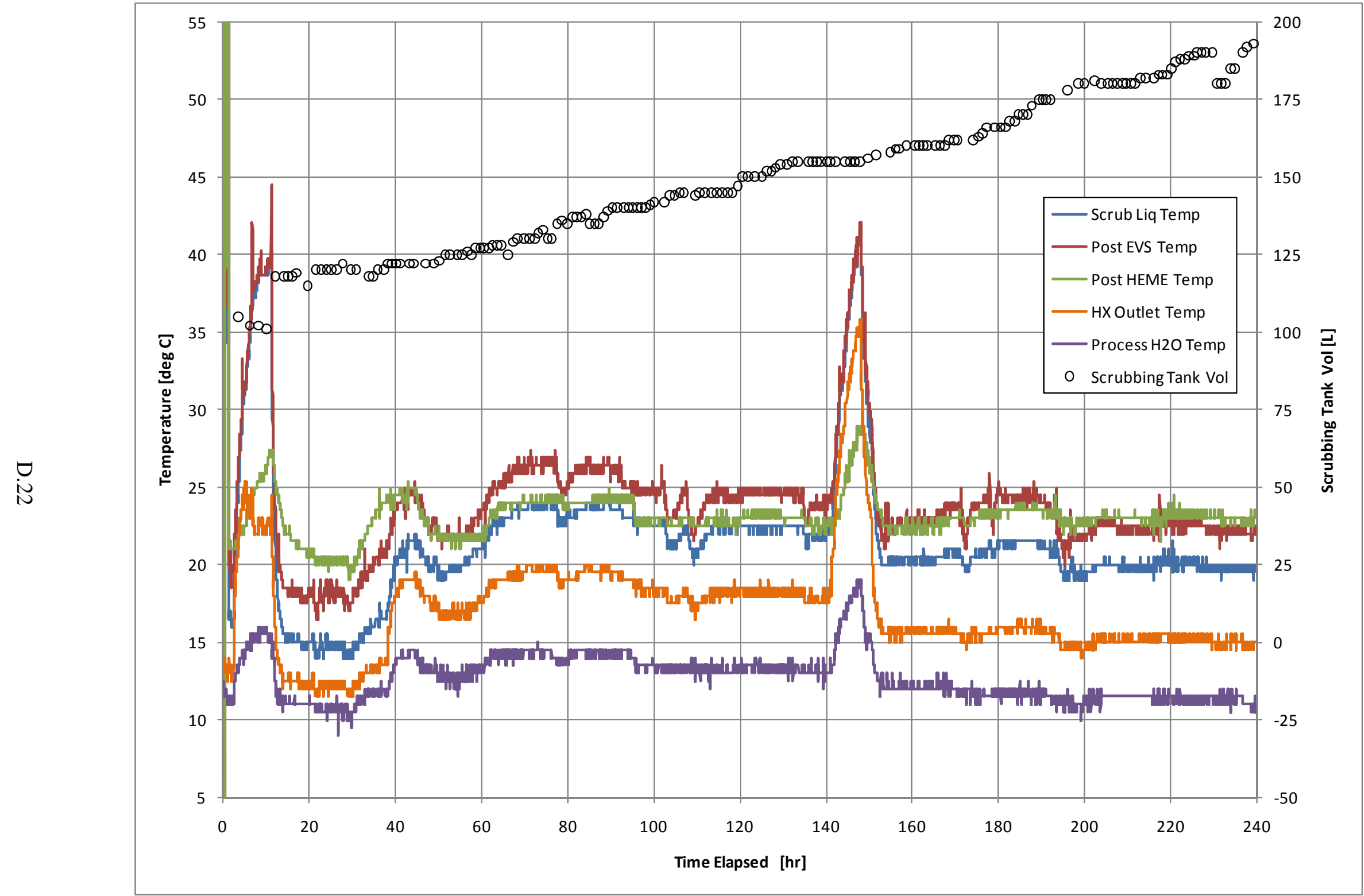

Figure D.22. Scrubbing Liquid, Post-EVS, Post-HEME, Heat Exchanger Outlet, and Process Water Temperatures (scrubbing liquid tank volume included) 
PNNL-20670

EMSP-RPT-005

\section{Distribution*}

No. of

Copies

2 U.S. Department of Energy

Office of Environmental Management

SP Schneider

GL Smith

3 U.S. Department of Energy

Office of River Protection

TW Fletcher

BM Mauss

SH Pfaff

1 Idaho National Laboratory

N Soelberg

2 Savannah River National Laboratory

F Johnson

D Peeler

2 Mo-Sci Corporation

DE Day

CW Kim
No. of

Copies

$7 \quad$ Pacific Northwest National Laboratory

CM Fischer K6-24

DS Kim K6-24

ML Kimura K6-28

RA Peterson P7-22

MJ Schweiger K6-24

GJ Sevigny $\quad$ P7-27

JD Vienna K6-24

*All distribution will be made electronically. 


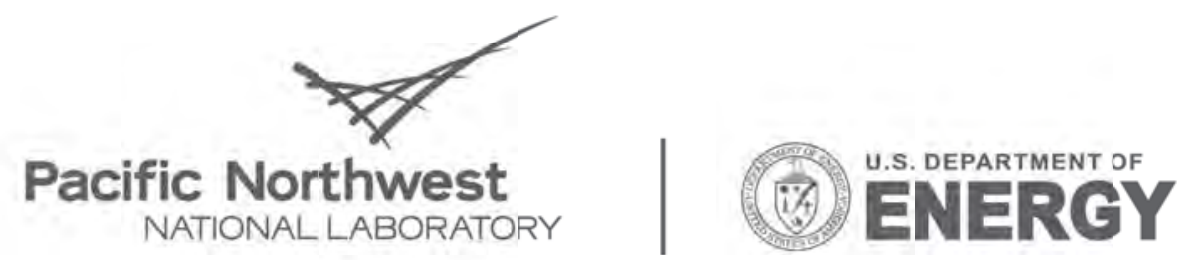

Proudly Operated by Baftelle Since 1965

902 Battelle Boulevard

P.O. Box 999

Richland, WA 99352

1-888-375-PNNL (7665)

www.pnl.gov 